\title{
Synthesis of (-)-Picrotoxinin by Late-Stage Strong Bond Activation
}

Steven W. M. Crossley ${ }^{+}$, Guanghu Tong ${ }^{+}$, Michael J. Lambrecht, Hannah Burdge, Ryan A. Shenvi*

Department of Chemistry, The Scripps Research Institute

10550 North Torrey Pines Road, La Jolla, CA 92037

\section{Table of Contents}

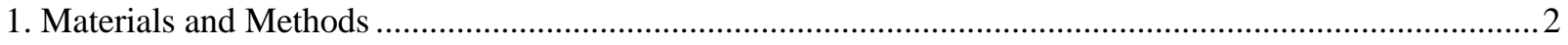

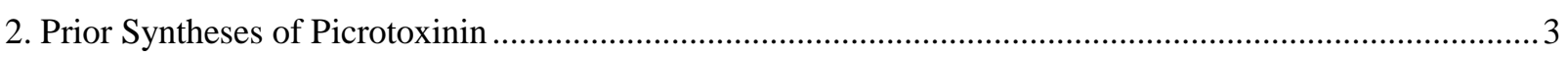

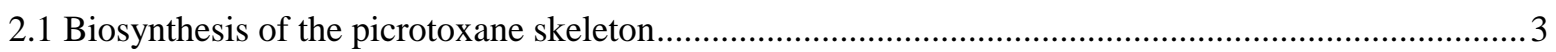

2.2 Corey (1979)

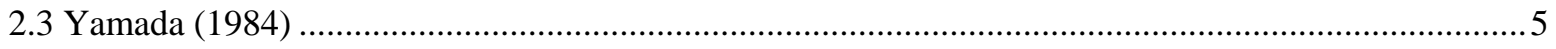

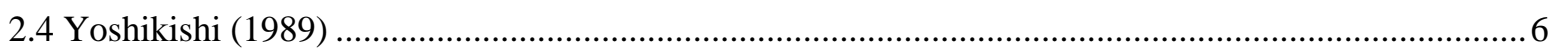

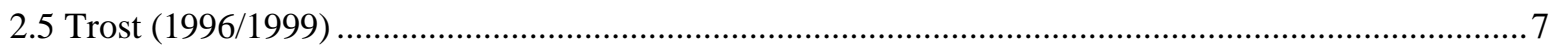

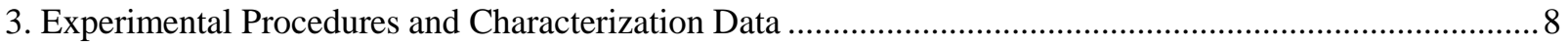

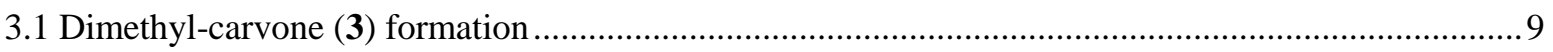

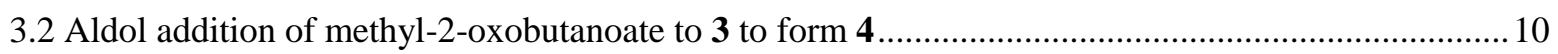

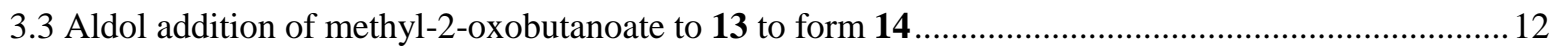

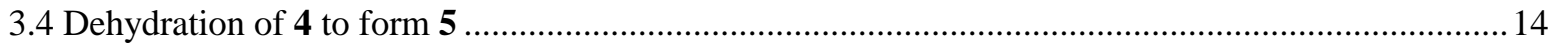

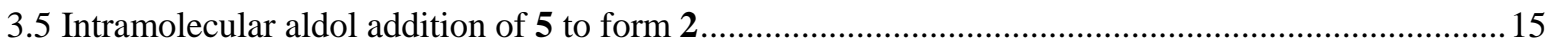

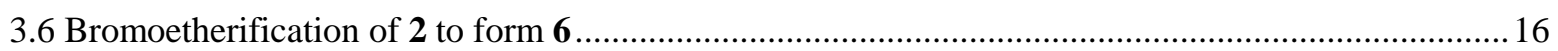

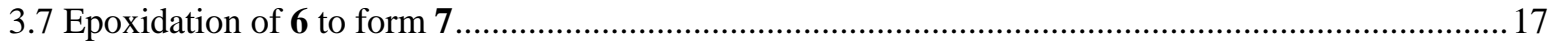

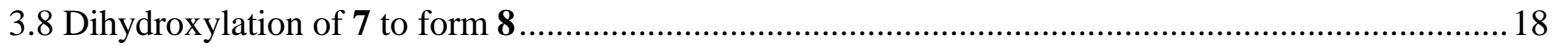

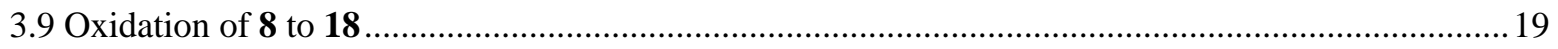

3.10 Reductive debromination of $\mathbf{1 8}$ to form 5-methyl-picrotoxinin $(\mathbf{2 0})$..............................................20

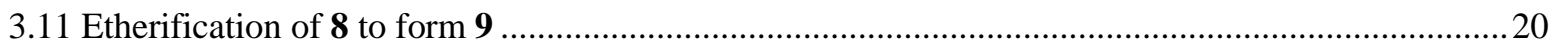

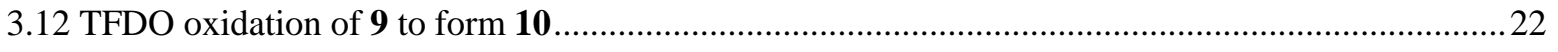

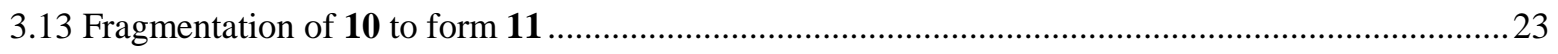

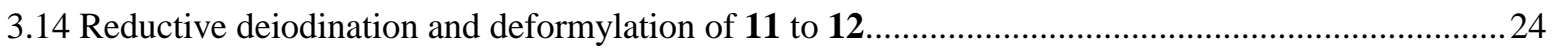

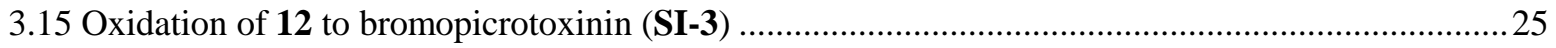

3.16 Reductive debromination of bromopicrotoxinin (SI-3) to form picrotoxinin (1) ............................26

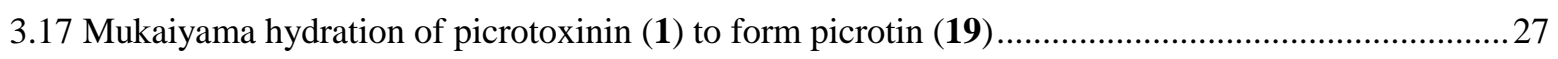

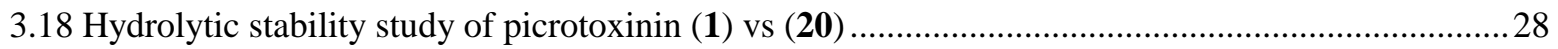

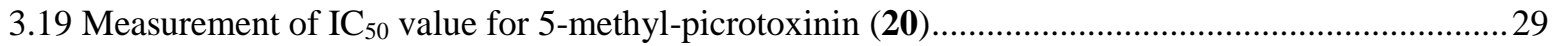

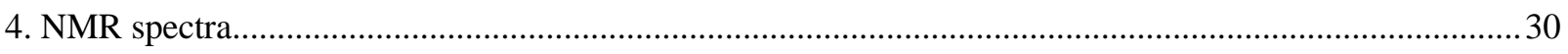

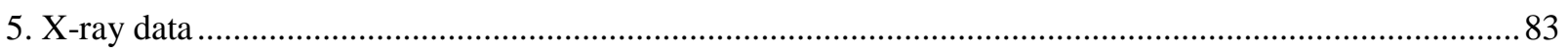

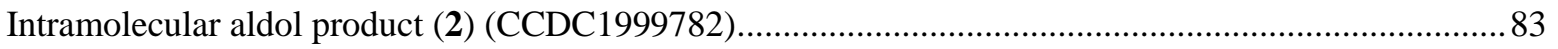

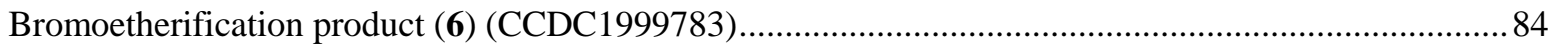

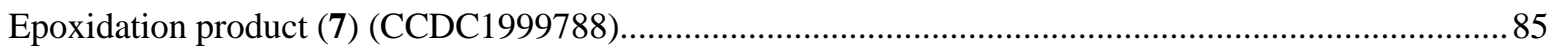

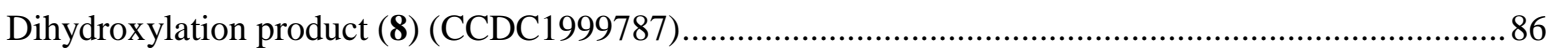


Ketone 15 (CCDC1999786)

des-Br-12 (CCDC1999791)

5-methyl-bromopicrotoxinin (18) (CCDC1999789).

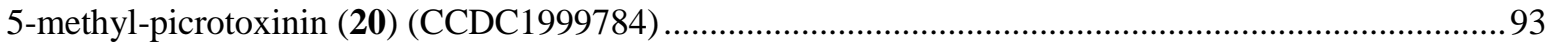

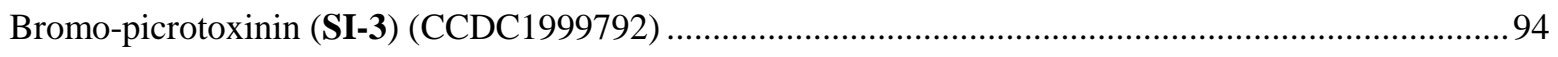

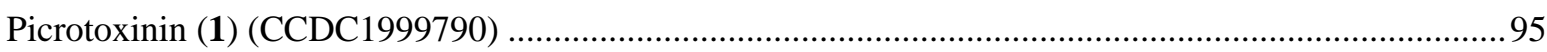

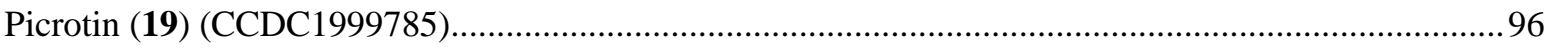

\section{Materials and Methods}

Pentane, hexanes, dichloromethane (DCM), toluene, ethyl acetate (EtOAc), diethyl ether, benzene, dimethylsulfoxide (DMSO), methanol (MeOH), $N$-dimethylformamide (DMF), dichloroethane (DCE), $\alpha, \alpha, \alpha-$ trifluorotoluene and triethylamine were purchased from Sigma Aldrich, EMD Chemicals, Fisher Chemicals or Acros Organics and used without further purification. All anhydrous solvents were purchased from Fisher Chemicals, Sigma Aldrich or Acros Organics and used without further purification, unless otherwise stated. Reactions were monitored by thin layer chromatography (TLC) with precoated silica gel plates from EMD Chemicals (TLC Silica gel 60 F254, $250 \mu$ m thickness) using UV light as the visualizing agent and an acidic mixture of anisaldehyde, phosphomolybdic acid (PMA), chromic acid, iodine vapor, Seebach's stain, or basic aqueous potassium permanganate $\left(\mathrm{KMnO}_{4}\right)$, and heat as developing agents. Preparatory thin layer chromatography (PTLC) was performed using the aforementioned silica gel plates. Flash column chromatography was performed over silica gel 60 (particle size 0.035- $0.07 \mathrm{~mm}$ ) from Acros Organics. NMR spectra were recorded on Bruker DRX-600 (equipped with a 5mm DCH Cryoprobe), AV-600, DRX-500 or DPX-400 and calibrated using residual non-deuterated solvent as an internal reference $\left(\mathrm{CHCl}_{3} @ 7.26 \mathrm{ppm}{ }^{1} \mathrm{H}\right.$ NMR, 77.16 ppm ${ }^{13} \mathrm{C}$ NMR; $\left(\mathrm{CD}_{3}\right)_{2} \mathrm{CO} @ 2.05 \mathrm{ppm}{ }^{1} \mathrm{H}$ NMR, $\left.206.26 \mathrm{ppm}{ }^{13} \mathrm{C} \mathrm{NMR}\right)$. The following abbreviations (or combinations thereof) were used to explain the multiplicities: $\mathrm{s}=$ singlet, $\mathrm{d}=$ doublet, $\mathrm{t}=$ triplet, $\mathrm{q}=$ quartet, $\mathrm{p}=$ pentet, $\mathrm{sex}=$ sextet, $\mathrm{sep}=$ septet $\mathrm{m}=$ multiplet, $\mathrm{br}=$ broad. LC/MS analysis was performed on an Agilent 1200 series HPLC/MS equipped with an Agilent SB-C18 $2.1 \mathrm{~mm}$ x $50 \mathrm{~mm}$ column, with mass spectra recorded on a 6120 Quadrupole mass spectrometer (API-ES), using $\mathrm{ACN}$ and $\mathrm{H}_{2} \mathrm{O}$ as the mobile phase $(0.1 \%$ formic acid). LC/MS runs used the following method unless otherwise specified: flow rate of $0.5 \mathrm{~mL} / \mathrm{min}$ is used, initial equilibration of $5 \% \mathrm{ACN} / \mathrm{H}_{2} \mathrm{O}$ with a linear gradient to $95 \% \mathrm{ACN} / \mathrm{H}_{2} \mathrm{O}$ over 5 minutes, then a hold at $95 \% \mathrm{ACN} / \mathrm{H}_{2} \mathrm{O}$ for an additional 3 minutes. GC/MS analysis was performed on Agilent 7820A/5975 GC/MSD system with helium as a carrier gas. Unless otherwise specified, GC/MS runs were performed with the following method: GC/MSD; HP-5MS (30m x 0.25mm ID, part \# 19091S-433); $139 \mathrm{KPa}$; flow rate $2 \mathrm{~mL} / \mathrm{min}$; inlet temperature $250{ }^{\circ} \mathrm{C}$; column temperature $50{ }^{\circ} \mathrm{C}$ for $0 \mathrm{~min}$, then $20^{\circ} \mathrm{C} / \mathrm{min}$ to $280{ }^{\circ} \mathrm{C}$, then held for $2 \mathrm{~min}$. GC/FID analysis was conducted on an Agilent 7820A GC/FID system with nitrogen as a carrier gas and with air and hydrogen as combustion gasses. Unless otherwise specified, GC/FID runs were prepared with the following method: GC/FID; HP-5MS UI (20m x 0.180mm ID, part \# 190915-577UI); inlet temperature $250{ }^{\circ} \mathrm{C}$; column temperature $50{ }^{\circ} \mathrm{C}$ for $0 \mathrm{~min}$, then $20^{\circ} \mathrm{C} / \mathrm{min}$ to $280^{\circ} \mathrm{C}$, then held for $2 \mathrm{~min}$. Chiral HPLC analysis was performed on Agilent 1100 series equipped with a DAD detector. Chiralcel OZ-3, $3 \mu \mathrm{m}$ particle size, $250 \mathrm{~mm}$ x $6 \mathrm{~mm}$ column; flow rate $1 \mathrm{~mL} / \mathrm{min}$ with solvent mixture of $98 \%$ hexanes and $2 \%$ isopropanol; detection wavelength $210 \mathrm{~nm}$. Optical rotations of arylated menthol derivatives were measured digitally on an Autopol III polarimeter from Rudolph Research Analytic, using a flow cell with a 0.5 decimeter pathlength and the sodium lamp D-line wavelength $(\lambda=589.3 \mathrm{~nm})$. High resolution mass spectrometric data were obtained on a Waters Xevo G2-XS TOF instrument (http://www.waters.com/webassets/cms/library/docs/720005089en.pdf). Calculated HRMS 
data were obtained by input of the $(\mathrm{M}+\mathrm{H})$ chemical formulae into the Exact Mass Calculator, Single Isotope Version at (https://www.sisweb.com/referenc/tools/exactmass.htm?formula).

Unless otherwise noted, all experiments were run in flame-dried glassware under an atmosphere of argon gas.

2. Prior Syntheses of Picrotoxinin

2.1 Biosynthesis of the picrotoxane skeleton

1. Edwards, O. E.; Douglas, J. L.; Mootoo, B. Biosynthesis of dendrobine. Can. J. Chem. 1970, 48, 2517.

2. Gössinger, E. Picrotoxanes. Progress in the Chemistry of Organic Natural Products, vol. 93, 2010, Springer.

3. Porter, L. A. Picrotoxinin and Related Substances. Chem. Rev. 1967, 67, 441-464.

4. Coscia, C. J. Picrotoxin. Cyclopentanoid Terpene Derivatives" 1968, pp. 147-201.

5. Cordell, G. A. Biosynthesis of Sesquiterpenes. Chem. Rev. 1976, 76, 425-460.

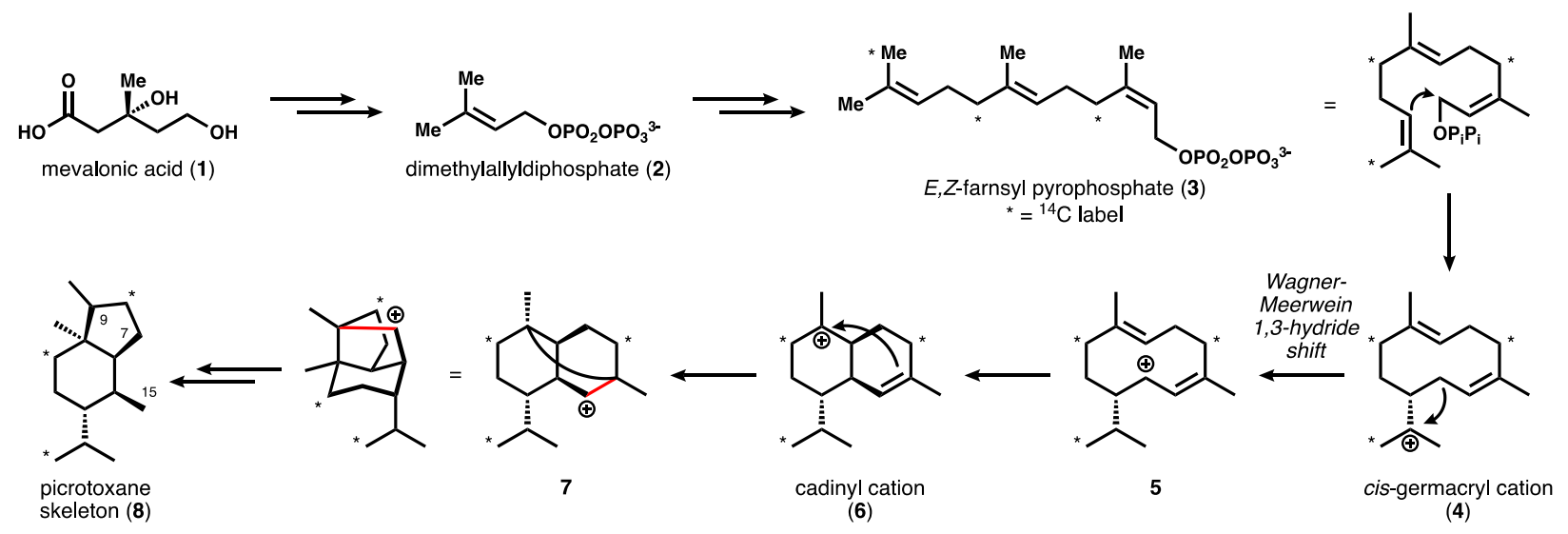


1. Corey, E. J.; Pearce, H. L. Total Synthesis of Picrotoxinin. J. Am. Chem. Soc. 1979, 101, 5841-5843.

2. Corey, E. J.; Pearce, H. L. Total Synthesis of Picrotin. Tetrahedron Lett. 1980, 21, 1823-1824.

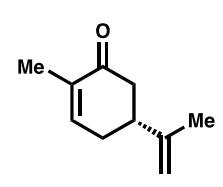

$(R)-(-)$-carvone
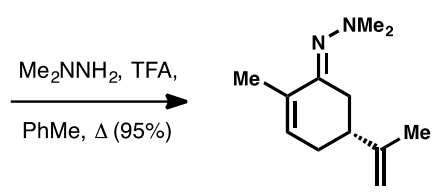

$-60{ }^{\circ} \mathrm{C} \rightarrow 0^{\circ} \mathrm{C}$
(85\%, d.r. 3:2,
not separated)

2. $\mathrm{NaOAc}, \mathrm{HOAc} /$

$\mathrm{THF} / \mathrm{H}_{2} \mathrm{O}, 25^{\circ} \mathrm{C}$
$(95 \%)$
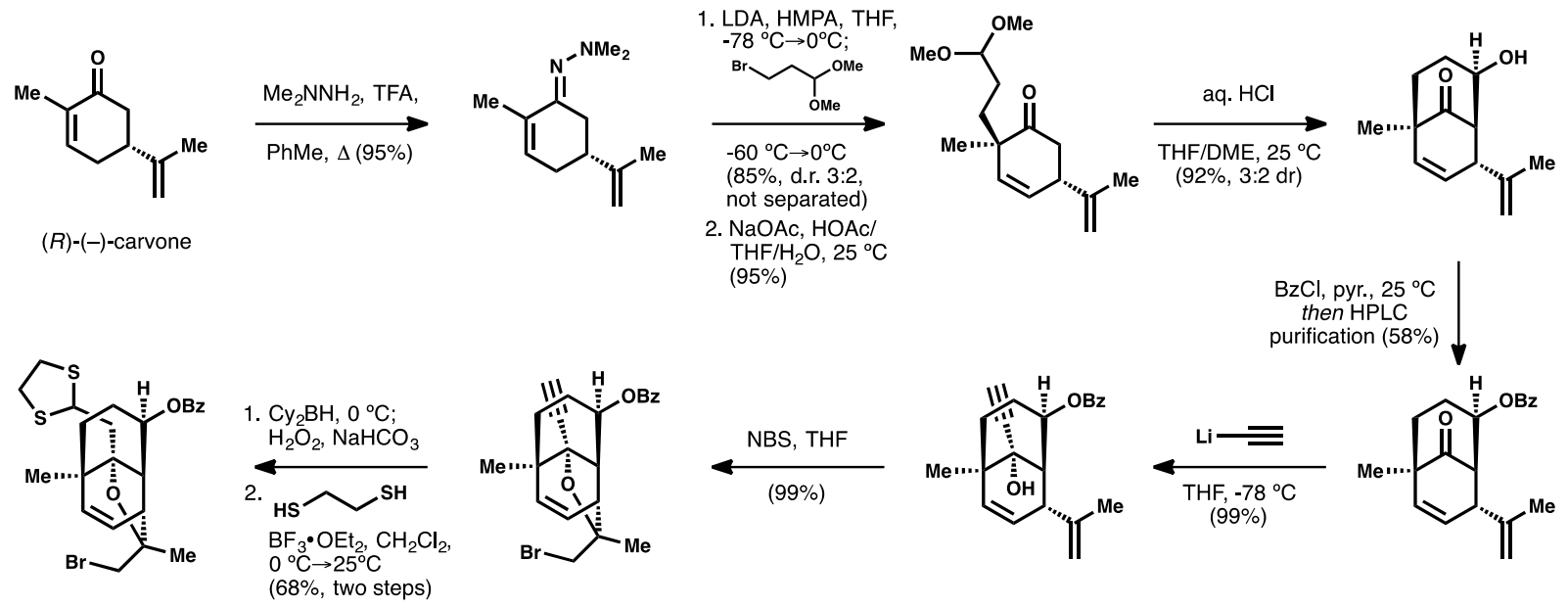

1. $\mathrm{K}_{2} \mathrm{CO}_{3}, \mathrm{MeOH}, 70^{\circ} \mathrm{C}$ 2. PCC, DMF, $0^{\circ} \mathrm{C}(95 \%)$

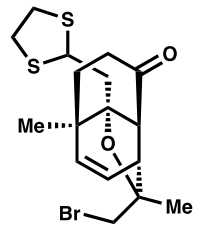
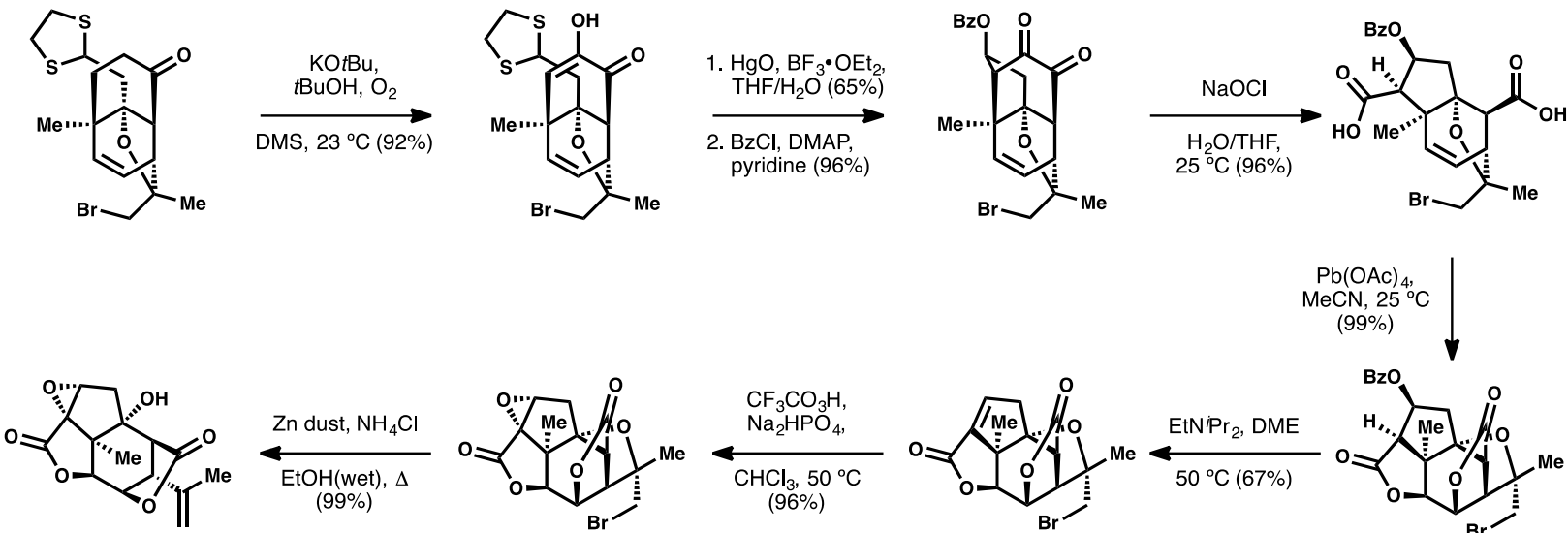

picrotoxinin
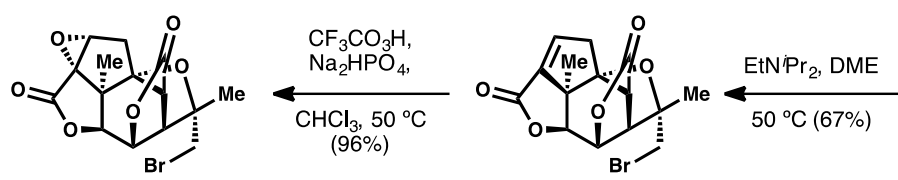

$\mathrm{Pb}(\mathrm{OAc})_{4}$,
$\mathrm{MeCN}, 25^{\circ} \mathrm{C}$ (99\%)

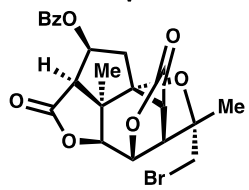


2.3 Yamada (1984)

1. Yamada, K.; K. Nagase, H.; Hayakawa, Y.; Aoki, K.; Hirata, Y. Synthetic Studies on Spirovetivanes. I. Spirocondensation of a 4-(3'-formylpropyl)-3-cyclohexenone and Stereospecific Total Synthesis of d1- $\beta$-vetivone. Tetrahedron Lett. 1973, 14, 4963-4966.

2. Niwa, N.; Wakamatsu, K.; Hida, T.; Niiyama, K.; Kigoshi, H.; Yamada, M.; Nagase, H.; Suzuki, M.; Yamada, K. Stereocontrolled Total Synthesis of (-)-Picrotoxinin and (+)-Coriamyrtin via a Common Isotwistane Intermediate. J. Am. Chem. Soc. 1984, 106, 4547-4552.<smiles>Cc1ccc(CCC(=O)O)c(O)c1</smiles><smiles>CC1(C)CCCCC1CCCC1OCCO1</smiles>
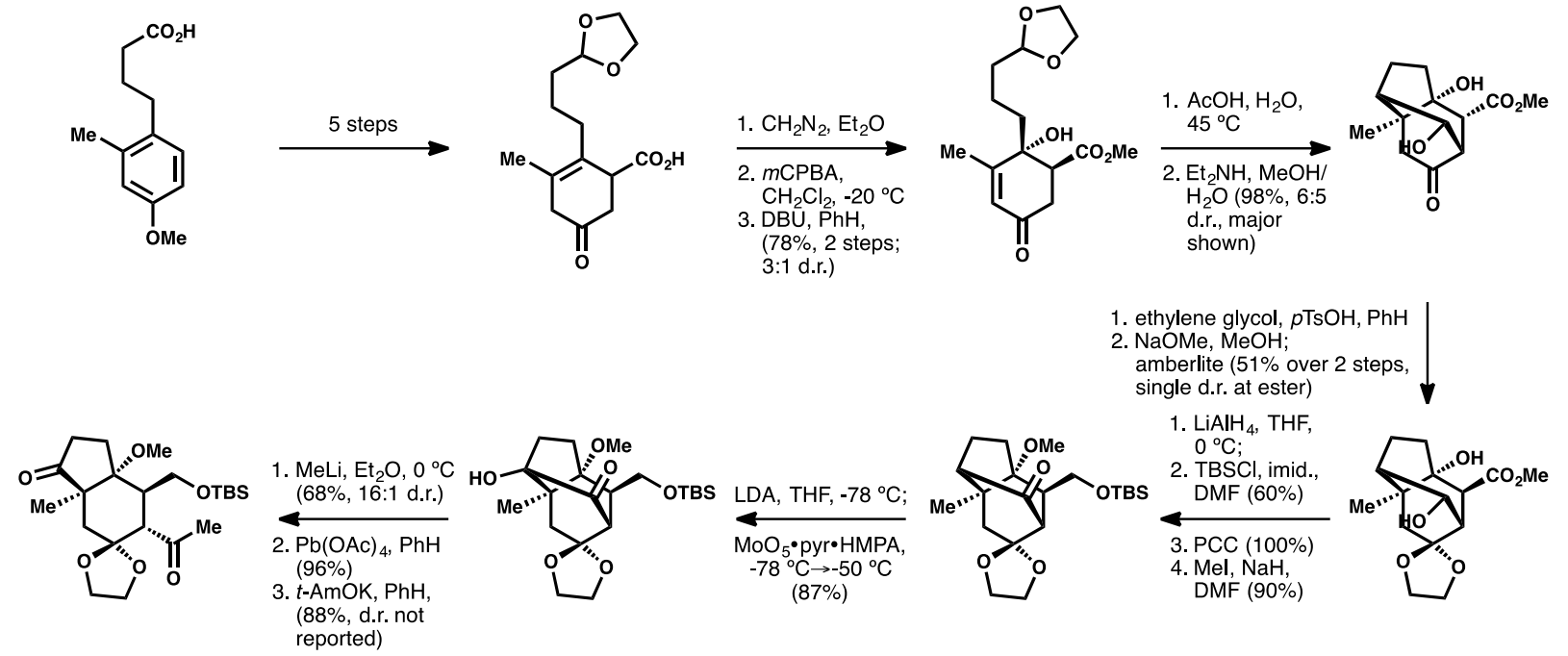

$$
\mid \begin{aligned}
& \text { 1. }(\mathrm{PhS}(\mathrm{O}) \mathrm{NMe}) \mathrm{CH}_{2} \mathrm{Li}, \\
& \text { THF, } \mathrm{O}^{\circ} \mathrm{C}(68 \%) ; \\
& \text { 2. } \mathrm{Al}-\mathrm{Hg}, \mathrm{THFI} \\
& \mathrm{AcOH}, \mathrm{H}_{2} \mathrm{O}(67 \%)
\end{aligned}
$$
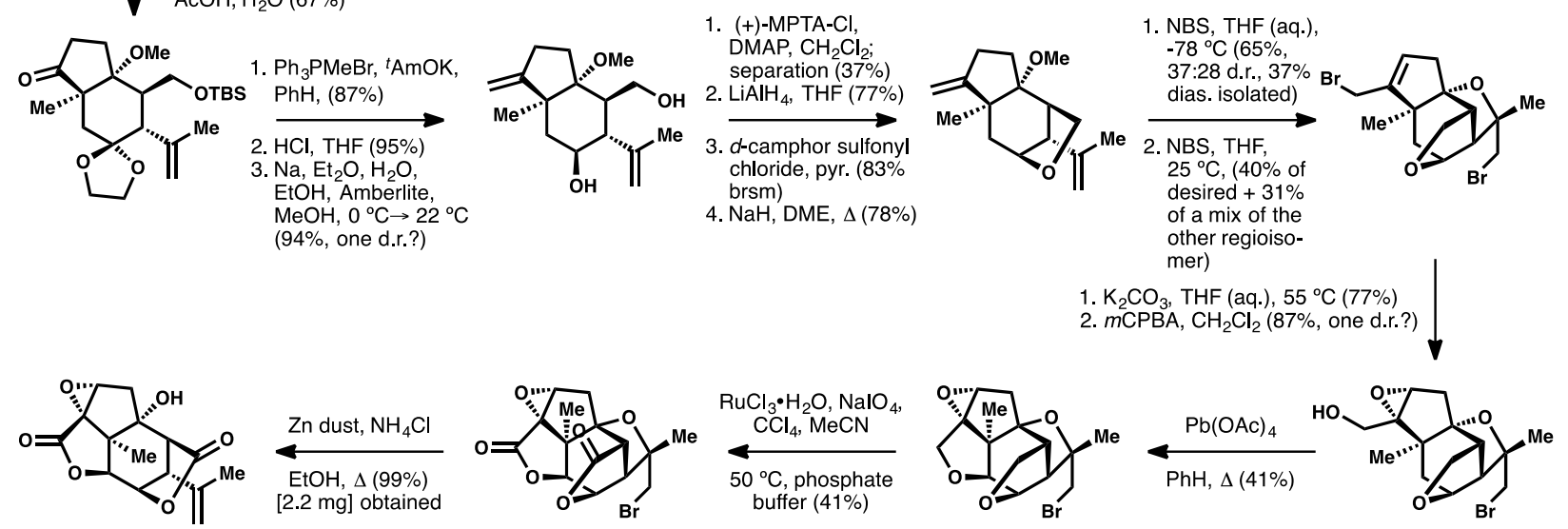

picrotoxinin 


\subsection{Yoshikishi (1989)}

1. Miyashita, M.; Suzuki, T.; Yoshikishi, A. Stereoselective Total Synthesis of (-)-Picrotoxinin and (-)Picrotin. J. Am. Chem. Soc. 1989, 111, 3728-3734.

2. Miyashita, M.; Sukuki, T.; Yoshikishi, A. Highly Efficient Conversion of (-)-carvone to (+)- $\beta$ hydroxycarvone. J. Org. Chem. 1985, 50, 3377-3380.
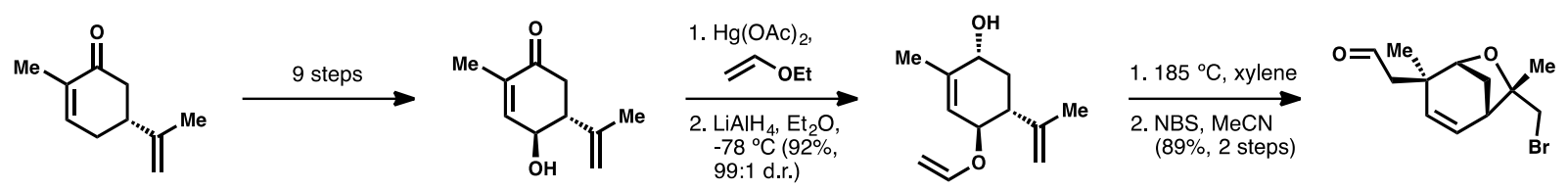

$(R)-(-)$-carvone
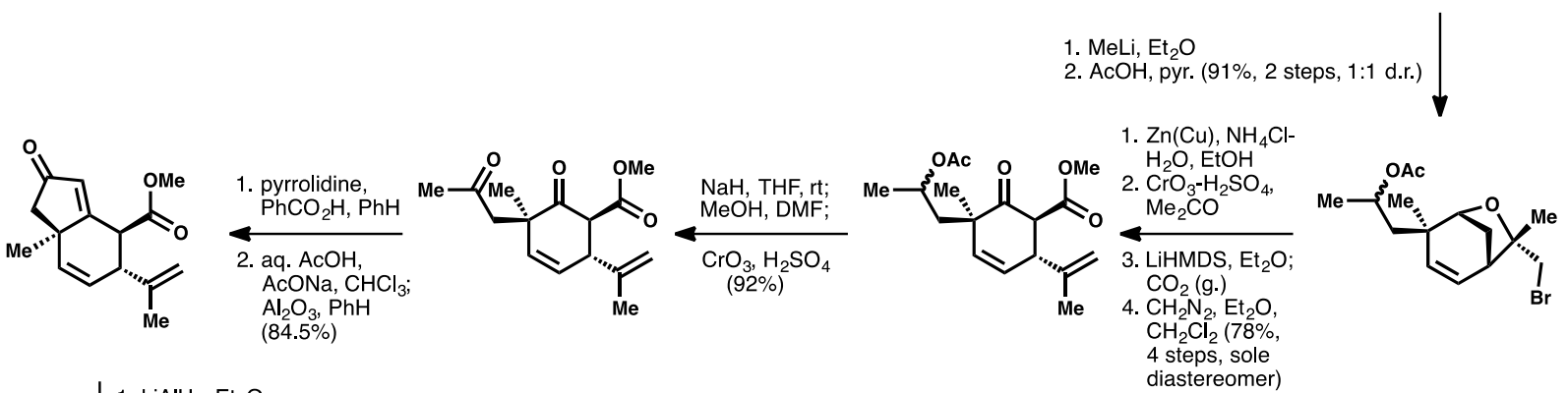

2. $\mathrm{MnO}_{2}, \mathrm{CH}_{2} \mathrm{O}$

3. $\mathrm{H}_{2} \mathrm{O}_{2}, \mathrm{NaOH}, \mathrm{MeOH}$ (single d.r.)

4. $\mathrm{Ac}_{2} \mathrm{O}$, pyr., DMAP, $\mathrm{CH}_{2} \mathrm{Cl}_{2}(75 \%, 4$ steps $)$<smiles>C=C(C)[C@@H]1C=C[C@@]2(C)CC(=O)[C@@H]3O[C@@]32[C@@H]1COC(C)=O</smiles>

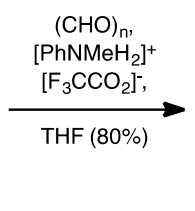<smiles>C=C(C)[C@@H]1C=C[C@]2(C)C(=C)C(=O)C3O[C@@]32[C@@H]1COC(C)=O</smiles>
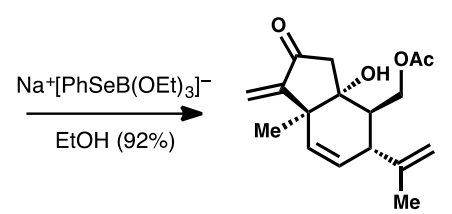

1. NBS, THF $(88 \%)$

2. $\mathrm{NaBH}_{4}, \mathrm{CeCl}_{3}{ }^{\circ}$

$7 \mathrm{H}_{2} \mathrm{O}, \mathrm{MeOH}$

3. $\mathrm{MsCl}$, pyr.

4. $\mathrm{OsO}_{4}$, pyr.; $\mathrm{NaHSO}_{3}($ aq

5. DBU, DMF

(81\%, 4 steps)

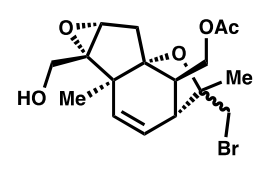

[27.1\% from $\beta$-hydroxy carvone]

1. $\mathrm{CrO}_{3} \cdot$ pyr., $\mathrm{CH}_{2} \mathrm{Cl}_{2}$

2. $\mathrm{NaClO}_{4}, \mathrm{NaH}_{2} \mathrm{PO}_{4}, \mathrm{H}_{2} \mathrm{O}$

2-methyl-2-butene, ${ }^{\mathrm{B}} \mathrm{BuOH}$

3. $\mathrm{CH}_{2} \mathrm{~N}_{2} \bullet \mathrm{Et}_{2} \mathrm{O}$ (81\%, 3 steps)
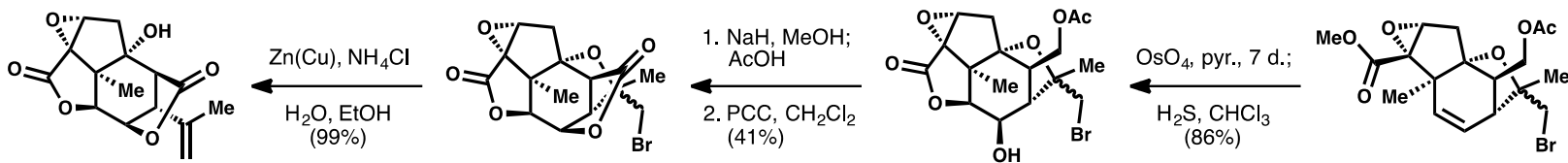

picrotoxinin

$3.8 \mathrm{mg}$. [5\% from

$\beta$-hydroxy carvone

$2.2 \%$ from carvone] 


\subsection{Trost (1996/1999)}

(Scheme depicts the first-generation synthesis)

1. Trost, B. M.; Krische, M. J. General Strategy for the Asymmetric Synthesis of the Picrotaxanes. J. Am. Chem. Soc. 1996, 118, 233-234.

2. Trost, B. M.; Haffner, C. D.; Jebaratnam, D. J.; Krishe, M. J.; Thomas, A. P. The Palladium-Catalyzed Enyne Cycloisomerization Reaction in a General Approach to the Asymmetric Syntheses of the Picrotoxane Sesquiterpenes. Part 1. First-Generation Total Synthesis of Corianin and Formal Syntheses of Picrotoxinin and Picrotin. J. Am. Chem. Soc. 1999, 121, 6183-6192.

3. Trost, B.; Krische, M. J. Palladium-Catalyzed Enyne Cycloisomerization Reaction in an Asymmetric Approach to the Picrotoxane Sesquiterpenes. 2. Second-Generation Total Syntheses of Corianin, Picrotoxinin, Picrotin, and Methyl Picrotoxate. J. Am. Chem. Soc. 1999, 121, 6131-6141.<smiles>C=C(C)C1CC=C(C)C(=O)C1</smiles>

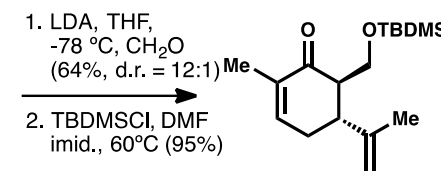

$(R)-(-)$-carvone
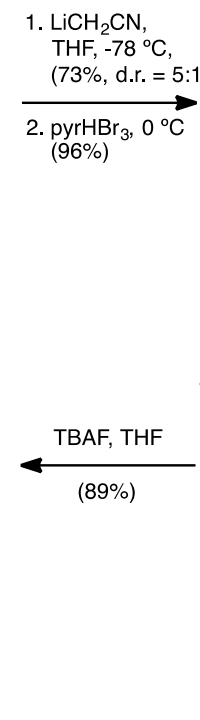<smiles>CC1=CC[C@H]2C(C)(CBr)[C@@]1(CBr)C2(CBr)O[C@H](C)O</smiles>

$\mathrm{Br}$ \begin{tabular}{l} 
1. DIBALH, PhMe, \\
$-78^{\circ} \mathrm{C} ;$ \\
$\mathrm{NaHSO}_{4}, \mathrm{H}_{2} \mathrm{O}$ \\
\hline $\begin{array}{l}\text { 2. } \mathrm{HC} \equiv \mathrm{CMgCl}, \mathrm{THF}, \\
0^{\circ} \mathrm{C}(2: 1 \text { d.r.) } \\
\text { (undesired d.r. }\end{array}$
\end{tabular} Mitsonobu rxn.)

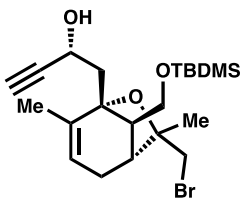

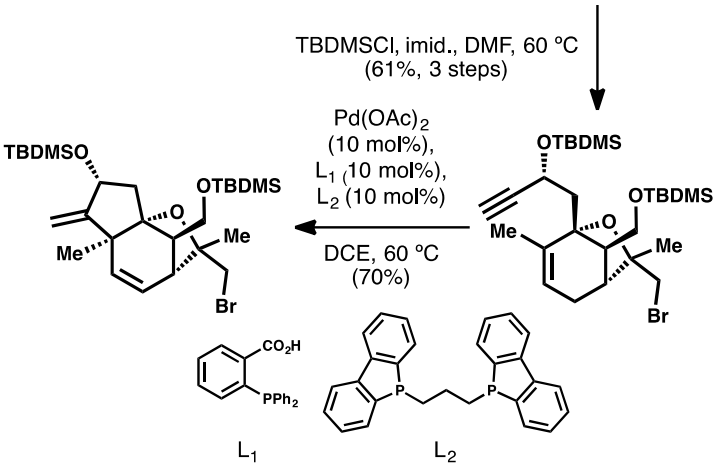
1. $\mathrm{CF}_{3} \mathrm{CO}_{3} \mathrm{H}, \mathrm{CSA}, \mathrm{CH}_{2} \mathrm{Cl}_{2}, \Delta(63 \%)$
2. $\mathrm{OsO}_{4}, \mathrm{pyr} .(75 \%)$
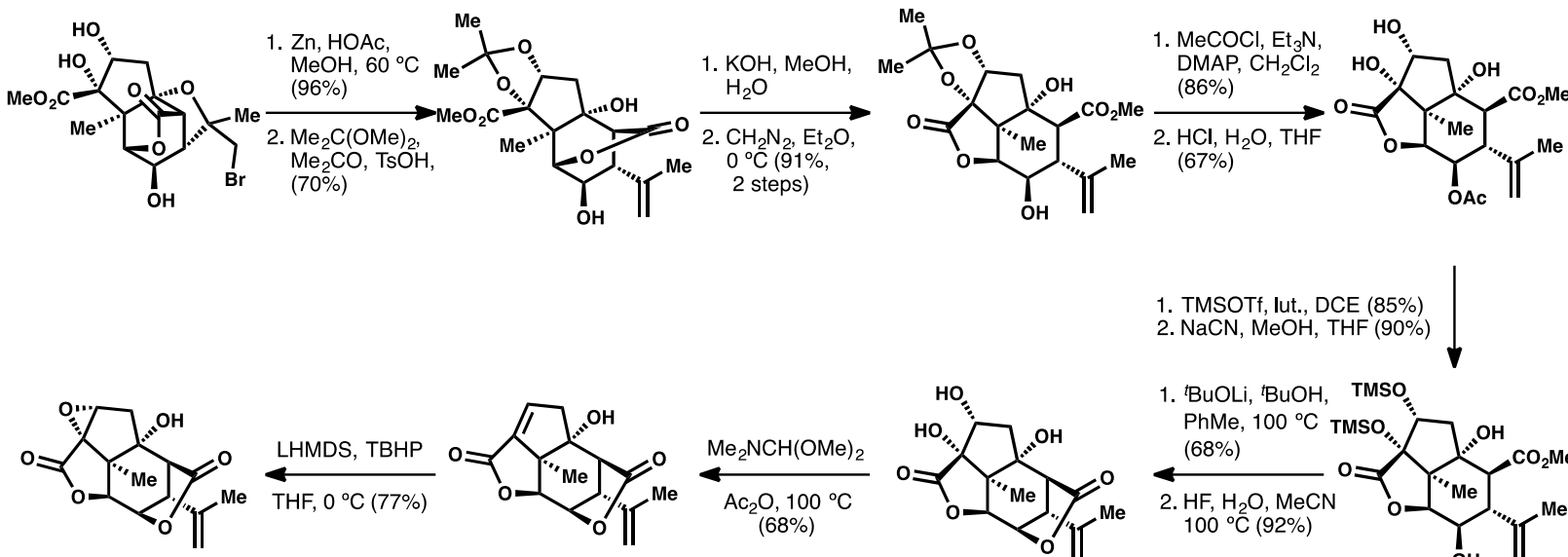

picrotoxinin

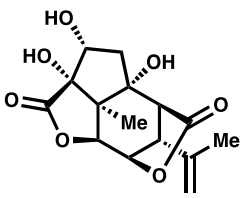

1. TMSOTf, lut., DCE ( $85 \%)$ 2. $\mathrm{NaCN}, \mathrm{MeOH}, \mathrm{THF}(90 \%)$

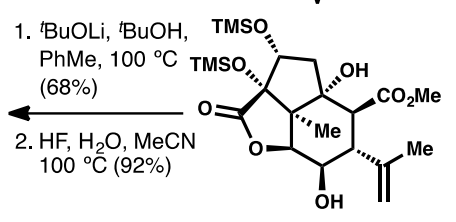




\section{Experimental Procedures and Characterization Data}

Scheme 1 from Main Text.
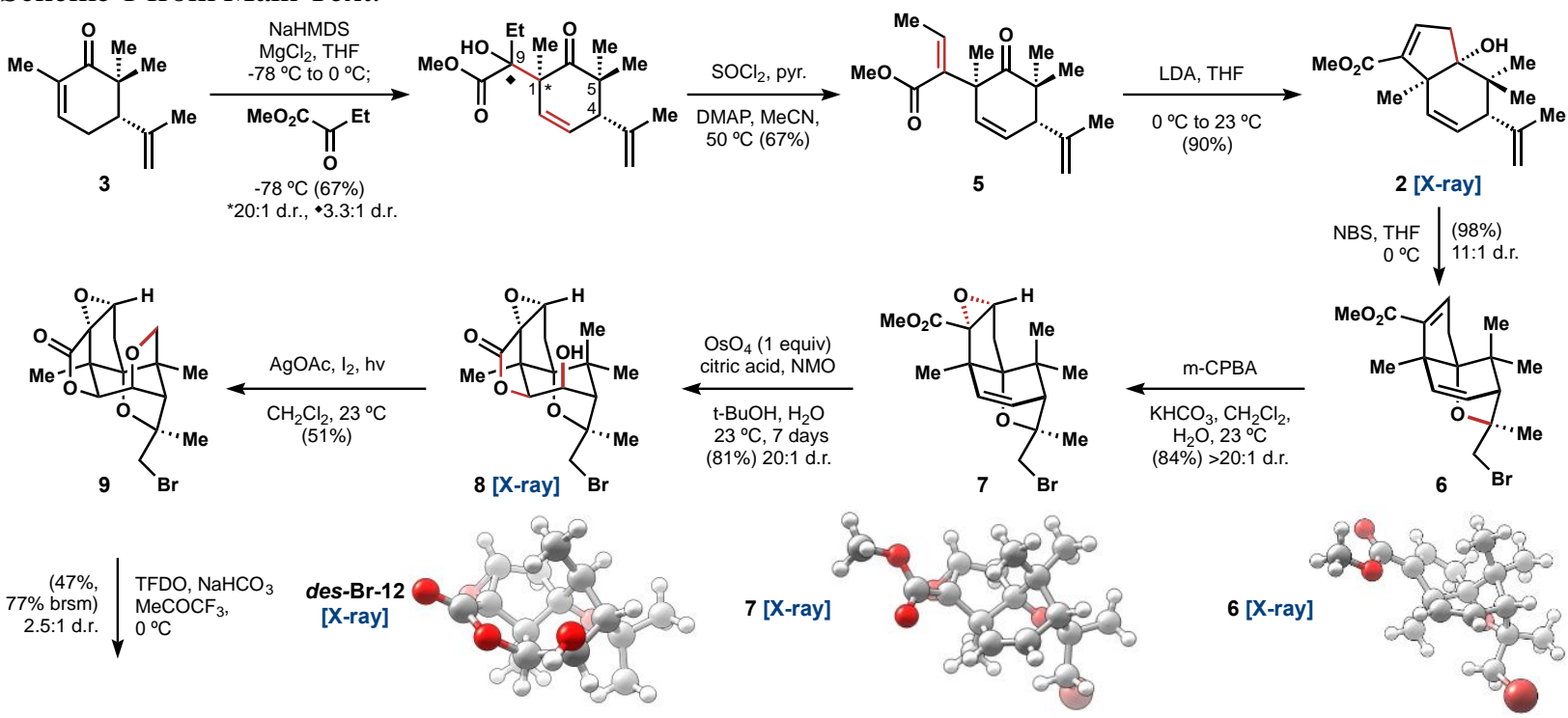

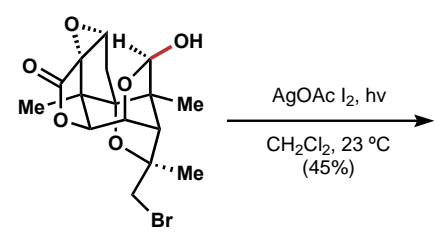

10

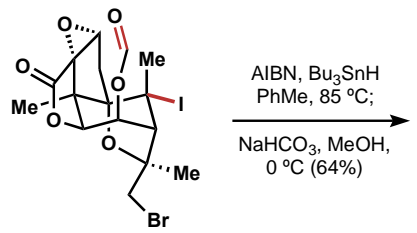

11

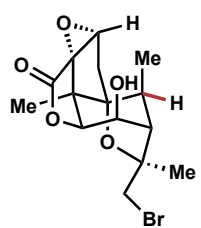

12
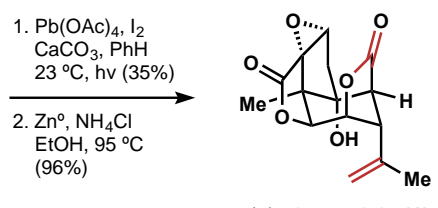

(-)-picrotoxinin (1)

[X-ray] 


\subsection{Dimethyl-carvone (3) formation}

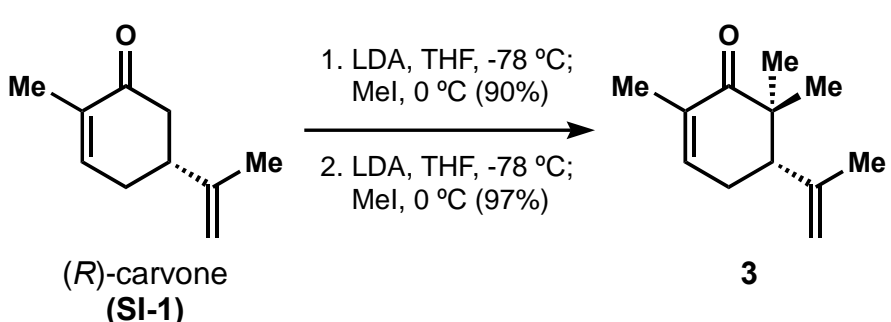

Procedure:

A $[0.33 \mathrm{M}]$ solution of LDA in THF was formed by addition of $n \mathrm{BuLi}$ in hexanes [2.67 M] (1.2 equiv, 240.0 mmol, $90 \mathrm{~mL}$ ) to a solution of diisopropylamine (distilled off $\left.\mathrm{CaH}_{2}\right)(1.5$ equiv, $300.0 \mathrm{mmol}, 42.0 \mathrm{ml})$ in THF $\left(600 \mathrm{~mL},[0.5 \mathrm{M}]\right.$ wrt $\left.\mathrm{HN}^{i} \mathrm{Pr}_{2}\right)$ at $-78^{\circ} \mathrm{C}$. After addition, the solution was stirred at $0{ }^{\circ} \mathrm{C}$ for 30 minutes before cooling back to $-78^{\circ} \mathrm{C}$.

To a flame-dried $500 \mathrm{~mL}$ round bottom flask containing a $[0.33 \mathrm{M}]$ solution of LDA in THF (1.2 equiv, 240.0 $\mathrm{mmol}$, see above for preparation details) cooled to $-78^{\circ} \mathrm{C}$ in a dry ice/acetone bath under an argon atmosphere was added via cannula a [1M (ignoring carvone volume)] solution of $(R$ )-carvone (SI-1) (1 equiv, $200.0 \mathrm{mmol}$, $30 \mathrm{~g}, 31.3 \mathrm{~mL})$ in THF $(200 \mathrm{~mL})$. The addition took $\sim 10$ minutes and the solution turned from clear and pale yellow to yellow over the course of the addition. The reaction was allowed to stir for 105 minutes, at which point methyl iodide ( 2.0 equiv, $200.0 \mathrm{mmol}, 12.4 \mathrm{~mL}$ ) was added neat in a slow but steady stream to the carvone enolate solution. The reaction was then stirred at $0{ }^{\circ} \mathrm{C}$ in an ice water bath and monitored by TLC (5\% EtOAc/hex). Full consumption of carvone was observed after 60 minutes.

After completion, the reaction was quenched by pouring the reaction onto a $1: 1$ mixture of saturated $\mathrm{NH}_{4} \mathrm{Cl}$ (aq.): $\mathrm{H}_{2} \mathrm{O}(500 \mathrm{~mL})$. The aqueous layer was extracted with EtOAc $(3 \mathrm{x} \sim 250 \mathrm{~mL})$. The organic layer was washed 1x each with $\mathrm{Na}_{2} \mathrm{~S}_{2} \mathrm{O}_{3}$ (saturated, aq., $\sim 250 \mathrm{~mL}$ ) and brine (saturated, aq. $\sim 250 \mathrm{~mL}$ ), and then dried over $\mathrm{MgSO}_{4}$, filtered, and concentrated. A white precipitate crashed out of the solution during concentration on the rotovap (presumably a diisopropylamine HI salt). The solid was filtered off over a plug of celite, rinsing with hexanes. The yellow solution became increasingly yellow/orange upon concentration. Therefore, the solution was diluted in $500 \mathrm{~mL}$ of hexanes, washed $1 \mathrm{x}$ with $\mathrm{Na}_{2} \mathrm{~S}_{2} \mathrm{O}_{3}$ (saturated, aq., $\sim 100 \mathrm{~mL}$ ) which removed most of the yellow color, dried over $\mathrm{MgSO}_{4}$, filtered and concentrated. The crude residue was purified by fractional distillation on high vacuum. The desired mixture of $\alpha$-methyl-carvone isomers was distilled over as a colorless to slightly paleyellow oil at $\sim 125-130{ }^{\circ} \mathrm{C}$ (external temperature), $\sim 90-91{ }^{\circ} \mathrm{C}$ (internal temperature at distillation head) at a pressure of $<5$ torr. $\alpha$-methyl-carvone (1:1 cis:trans) was obtained $90 \%$ yield $(29.4 \mathrm{~g}, 180.0 \mathrm{mmol})$.

A second $[0.34 \mathrm{M}]$ solution of LDA in THF was formed by addition of $n \mathrm{BuLi}$ in hexanes (1.25 equiv, 225.0 mmol, $84 \mathrm{~mL}$ of $[2.67 \mathrm{M}]$ ) to a solution of diisopropylamine (distilled off $\mathrm{CaH}_{2}$ ) (1.5 equiv, $270.0 \mathrm{mmol}, 37.7$ $\mathrm{ml})$ in THF $\left(540 \mathrm{~mL},[0.5 \mathrm{M}]\right.$ with respect to $\left.\mathrm{HN}^{i} \mathrm{Pr}_{2}\right)$ at $-78^{\circ} \mathrm{C}$. After addition, the solution was stirred at $0{ }^{\circ} \mathrm{C}$ for 30 minutes before cooling back to $-78^{\circ} \mathrm{C}$.

To a flame-dried $500 \mathrm{~mL}$ round bottom flask containing the $[0.34 \mathrm{M}]$ solution of LDA in THF (1.2 equiv, 108.0 mmol, see above for preparation details) cooled to $-78^{\circ} \mathrm{C}$ in a dry ice/acetone bath under an argon atmosphere was added via cannula a [1M (ignoring $\alpha$-methyl-carvone volume)] solution of $\alpha$-methyl-carvone (1 equiv, 180.0 mmol, $29.4 \mathrm{~g})$ in THF $(180 \mathrm{~mL})$. The substrate solution was rinsed with a few $\mathrm{mL}$ of anhydrous THF after transfer. The solution was allowed to stir for 90 minutes, at which point methyl iodide (2.0 equiv, $180.0 \mathrm{mmol}$, 
$11.2 \mathrm{~mL}$ ) was added neat in slow but steady stream to the $\alpha$-methyl-carvone enolate solution. The reaction was then stirred at $0{ }^{\circ} \mathrm{C}$ in an ice water bath and monitored by TLC (10\% EtOAc/hex). After 1 hour, some starting material still remained by TLC (10\% EtOAc/hex). After two hours, there appeared to be no further conversion, so the solution was quenched.

The reaction was poured onto a 1:1 mixture of saturated $\mathrm{NH}_{4} \mathrm{Cl}$ (aq.): $\mathrm{H}_{2} \mathrm{O}(500 \mathrm{~mL})$. The aqueous layer was extracted with EtOAc $(1 \mathrm{x} \sim 250 \mathrm{~mL})$ and hexanes $(2 \mathrm{x} \sim 250 \mathrm{~mL})$. The organic layer was washed $1 \mathrm{x}$ each with $\mathrm{Na}_{2} \mathrm{~S}_{2} \mathrm{O}_{3}$ (saturated, aq., $\sim 250 \mathrm{~mL}$ ) and brine (saturated, aq., $\sim 250 \mathrm{~mL}$ ) and then dried over $\mathrm{MgSO}_{4}$, filtered, and concentrated. The residue turned increasingly yellow (NOTE 1 ) and cloudy during concentration, so the residue was dissolved in $\sim 150 \mathrm{~mL}$ of hexanes and washed a second times with $\mathrm{Na}_{2} \mathrm{~S}_{2} \mathrm{O}_{3}$ (saturated, aq., $\sim 100 \mathrm{~mL}$ ). After separation, the organic layer was dried over $\mathrm{MgSO}_{4}$, filtered, and concentrated in vacuo. The reaction was purified by a fractional distillation on high vacuum. Dimethyl-carvone was distilled over as a colorless to slightly pale-yellow oil at $\sim 120-130{ }^{\circ} \mathrm{C}$ (external temperature), $\sim 80{ }^{\circ} \mathrm{C}$ (internal temperature at distillation head) at a pressure of $<5$ torr. $\alpha$-methyl-carvone was obtained in $97 \%$ yield $(31.1 \mathrm{~g}, 174.0 \mathrm{mmol})$. NMR analysis indicated a 1.00:0.03:0.03 mixture of dimethyl-carvone to $\alpha$-methyl-carvone isomers. This compound was used without further purification in the subsequent step and stored over solid copper in a tinted glass bottle (old $\mathrm{CDCl}_{3}$ bottle) away from light at $-20^{\circ} \mathrm{C}$.

NOTE 1: We speculate that the yellow/orange color that appears during concentration of the crude reaction is due to formation of iodine from aerobic oxidation of iodide salt in the presence of both $\alpha$-methyl-carvone and dimethylcarvone. The thiosulfate wash temporarily reduces the nascent iodine, but storage in air results in further oxidation. We recommend minimal storage time between work-up and purification by distillation.

\section{Characterization data of dimethyl-carvone (3):}

Description clear or pale-yellow oil

$\underline{R}_{f} \quad 0.44$ in 5\% EtOAc/hex. 0.56 in $10 \%$ EtOAc/hex. Stains purple in anisaldehyde.

Opt. Rot. $\quad \alpha_{o b s}=-10.7^{\circ}, \mathrm{c}=1.00$ in $\mathrm{CH}_{2} \mathrm{Cl}_{2}, \mathrm{~T}=22.9^{\circ} \mathrm{C}$

1 $\mathrm{H}$ NMR $\quad(600 \mathrm{MHz}$, Chloroform- $d)$

$\delta 6.61(\mathrm{ddt}, J=6.2,2.8,1.4 \mathrm{~Hz}, 1 \mathrm{H}), 4.86(\mathrm{p}, J=1.6 \mathrm{~Hz}, 1 \mathrm{H}), 4.77-4.65(\mathrm{~m}, 1 \mathrm{H}), 2.53(\mathrm{dd}, J$ $=7.7,5.4 \mathrm{~Hz}, 1 \mathrm{H}), 2.49-2.42(\mathrm{~m}, 1 \mathrm{H}), 2.44-2.35(\mathrm{~m}, 1 \mathrm{H}), 1.77(\mathrm{q}, J=1.8 \mathrm{~Hz}, 3 \mathrm{H}), 1.72-$ $1.66(\mathrm{~m}, 3 \mathrm{H}), 1.14(\mathrm{~s}, 3 \mathrm{H}), 1.03(\mathrm{~s}, 3 \mathrm{H})$.

${ }^{13} \mathrm{C} \mathrm{NMR} \quad(151 \mathrm{MHz}$, Chloroform- $d$ )

$\delta$ 204.7, 146.1, 142.4, 133.7, 113.9, 52.2, 44.8, 29.2, 24.6, 23.5, 20.5, 16.6.

HRMS Calculated $\mathrm{C}_{12} \mathrm{H}_{19} \mathrm{O}[\mathrm{M}+\mathrm{H}]: 179.1436$ Found: 179.1432

X-ray N/A, oil

3.2 Aldol addition of methyl-2-oxobutanoate to 3 to form $\mathbf{4}$

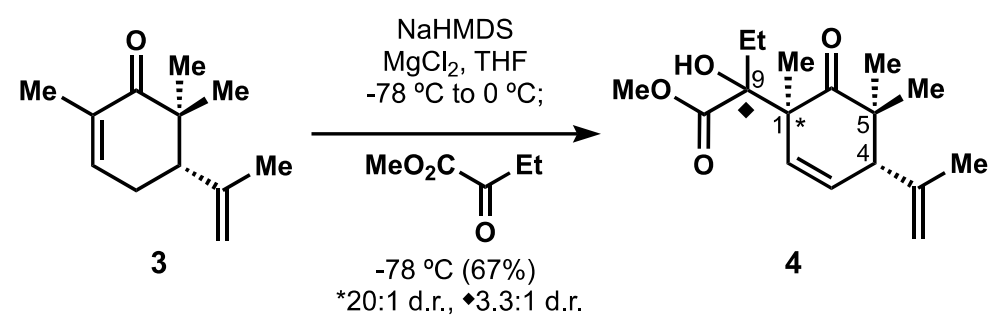




\section{Procedure:}

To a flame-dried round bottom flask charged with anhydrous $\mathrm{MgCl}_{2}(1.9 \mathrm{~g}, 20.0 \mathrm{mmol}, 2$ equiv, NOTE 1) was added a solution of freshly distilled dimethyl-carvone 3 (1.78 g, $10.0 \mathrm{mmol}, 1$ equiv) in anhydrous THF (100 $\mathrm{mL}$ ) at $23{ }^{\circ} \mathrm{C}$ for 20 minutes. NaHMDS ( $1 \mathrm{M}$ in THF, $15 \mathrm{~mL}, 15.0 \mathrm{mmol}, 1.5$ equiv) was added to the above mixture at $-78^{\circ} \mathrm{C}$. The reaction was vigorously stirred for an additional 30 minutes at $-78{ }^{\circ} \mathrm{C}$. The solution was placed in a $0{ }^{\circ} \mathrm{C}$ ice/water bath and stirred for 60 minutes at $0{ }^{\circ} \mathrm{C}$. Once the enolate was fully formed (NOTE 2), the solution was cooled back to $-78^{\circ} \mathrm{C}$ and methyl-2-oxobutanoate $(3.35 \mathrm{~mL}, 30.0 \mathrm{mmol}, 3.0$ equiv) was added neat to the enolate solution in a steady stream within a period of 5 minutes. After 75 minutes, the mixture was quenched by addition of saturated $\mathrm{NH}_{4} \mathrm{Cl} / \mathrm{H}_{2} \mathrm{O}(1: 1$, v:v, $20 \mathrm{~mL})$ at $-78{ }^{\circ} \mathrm{C}$ (NOTE 3). The reaction was then warmed to room temperature and extracted with EtOAc $(3 \times 150 \mathrm{~mL})$. The organic layer was washed with brine, dried over $\mathrm{Na}_{2} \mathrm{SO}_{4}$, filtered, and concentrated in vacuo. The crude residue was purified by flash column chromatography over silica gel ( $5 \%$ EtOAc/hex to $10 \%$ EtOAc/hex). The desired aldol addition products 4 were collected together (1.91 g, $6.7 \mathrm{mmol}, 67 \%, \mathrm{dr} \sim 3.3: 1$ at C-9, NOTE 4) as a pale-yellow oil.

NOTE 1: $\mathrm{MgCl}_{2}$ powder (weighed out assuming it is anhydrous) is further dried by heating with a heat gun under high vacuum until no more 'bubbling' of the powder occurs. The vessel is then placed under an argon atmosphere and other reagents are added to this reaction vessel.

NOTE 2: After 60 minutes, it is useful to TLC the enolate solution to confirm that the enolate has fully formed. Protonation at C-1 occurs upon TLC analysis to give the deconjugated isomer of dimethyl-carvone, which is less polar than dimethyl-carvone and not UV-active. Disappearance of the dimethyl-carvone spot is observed when the enolate has fully formed.

NOTE 3: The reaction must be quenched at $-78{ }^{\circ} \mathrm{C}$ because the retro-aldol reaction of the product occurs at warmer temperatures $\left(c a>\sim-20^{\circ} \mathrm{C}\right)$.

NOTE 4: The yield of this reaction between different runs ranged from 60-70\% and the diastereoselectivity between 2-3.3:1 at the C-9 alcohol. The opposite diastereomer at C-1 was never observed. The C-9 diastereomers can be collected separately after chromatographic separation. A 2.2:1 diastereomeric mixture at C-9 were separated and used for characterization of the two C-9 diastereomers.

Characterization data of aldol addition adduct (4, major diastereomer):

$\underline{\text { Description }}$ Faint yellow/colorless oil. Became a white waxy crystalline solid upon storage at $-20^{\circ} \mathrm{C}$.

$\underline{R}_{f} \quad 0.23$ in $15 \%$ EtOAc/hex. Weakly UV active. Stain purple in anisaldehyde.

Opt. Rot. $\quad \alpha_{\mathrm{obs}}=+58.9^{\circ}, \mathrm{c}=1.00$ in $\mathrm{CH}_{2} \mathrm{Cl}_{2}, \mathrm{~T}=25.6^{\circ} \mathrm{C}$

${ }^{1} \mathrm{H}$ NMR $\quad(600 \mathrm{MHz}$, Chloroform- $d$ )

$\delta 5.91(\mathrm{dd}, J=10.3,2.4 \mathrm{~Hz}, 1 \mathrm{H}), 5.80(\mathrm{dd}, J=10.3,3.1 \mathrm{~Hz}, 1 \mathrm{H}), 5.05(\mathrm{dq}, J=2.0,1.3 \mathrm{~Hz}, 1 \mathrm{H})$, $4.77(\mathrm{dt}, J=1.7,0.8 \mathrm{~Hz}, 1 \mathrm{H}), 3.87(\mathrm{~s}, 3 \mathrm{H}), 3.76(\mathrm{~s}, 1 \mathrm{H}), 3.15(\mathrm{t}, J=2.8 \mathrm{~Hz}, 1 \mathrm{H}), 1.98(\mathrm{dq}, J=$ $13.7,7.3 \mathrm{~Hz}, 1 \mathrm{H}), 1.81(\mathrm{dd}, J=1.5,0.8 \mathrm{~Hz}, 3 \mathrm{H}), 1.67(\mathrm{dq}, J=13.6,7.4 \mathrm{~Hz}, 1 \mathrm{H}), 1.34(\mathrm{~s}, 3 \mathrm{H})$, $1.11(\mathrm{~s}, 3 \mathrm{H}), 1.02(\mathrm{~s}, 3 \mathrm{H}), 0.76(\mathrm{t}, J=7.3 \mathrm{~Hz}, 3 \mathrm{H})$.

${ }^{13} \mathrm{C}$ NMR $\quad(151 \mathrm{MHz}$, Chloroform- $d$ )

$\delta 218.4,176.1,144.7,132.9,130.6,115.9,83.3,55.0,53.0,50.2,48.4,26.6,24.7,23.1,23.0$, 22.0, 7.6.

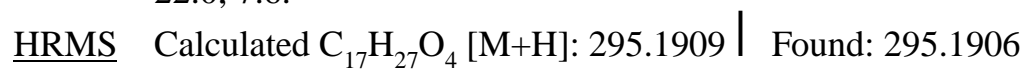

$\underline{X-r a y}$ not obtained

2D-NMR NOESY 


\section{Characterization data of aldol addition adduct $(\mathbf{4}$, minor diastereomer):}

Description Faint yellow/colorless oil. Became a white waxy crystalline solid upon extended storage at $-20^{\circ} \mathrm{C}$.

$\underline{R}_{f} 0.3$ in $15 \% \mathrm{EtOAc/hex.} \mathrm{Weakly} \mathrm{UV} \mathrm{active.} \mathrm{Stain} \mathrm{purple} \mathrm{in} \mathrm{anisaldehyde.}$

Opt. Rot. $\quad \alpha_{\mathrm{obs}}=-45.9^{\circ}, \mathrm{c}=1.00$ in $\mathrm{CH}_{2} \mathrm{Cl}_{2}, \mathrm{~T}=24.2^{\circ} \mathrm{C}$

1 H NMR $(600 \mathrm{MHz}$, Chloroform- $d$ )

$\delta 5.86(\mathrm{dd}, J=10.3,2.3 \mathrm{~Hz}, 1 \mathrm{H}), 5.52(\mathrm{dd}, J=10.4,3.2 \mathrm{~Hz}, 1 \mathrm{H}), 5.11-4.98(\mathrm{~m}, 1 \mathrm{H}), 4.75$

(dq, $J=1.7,0.8 \mathrm{~Hz}, 1 \mathrm{H}), 4.09(\mathrm{~d}, J=1.6 \mathrm{~Hz}, 1 \mathrm{H}), 3.76(\mathrm{~s}, 3 \mathrm{H}), 3.18(\mathrm{t}, J=2.8 \mathrm{~Hz}, 1 \mathrm{H}), 2.11$

(dq, $J=14.6,7.3 \mathrm{~Hz}, 1 \mathrm{H}), 1.90(\mathrm{dq}, J=14.7,7.4 \mathrm{~Hz}, 1 \mathrm{H}), 1.84-1.78(\mathrm{~m}, 3 \mathrm{H}), 1.32(\mathrm{~s}, 3 \mathrm{H})$, $1.13(\mathrm{~s}, 3 \mathrm{H}), 0.99$ (s, 3H), 0.79 (t, $J=7.3 \mathrm{~Hz}, 3 \mathrm{H})$.

${ }^{13} \mathrm{C}$ NMR $\quad(151 \mathrm{MHz}$, Chloroform- $d)$

$\delta 218.5,175.2,144.7,133.1,130.4,116.0,84.3,52.7,52.4,50.2,48.5,26.0,24.5,23.2,22.6$, 22.4, 8.1.

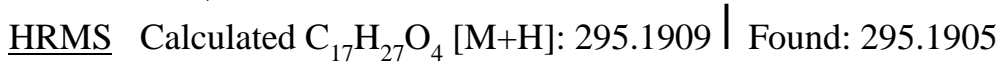

X-ray not obtained

2D-NMR NOESY

3.3 Aldol addition of methyl-2-oxobutanoate to $\mathbf{1 3}$ to form $\mathbf{1 4}$

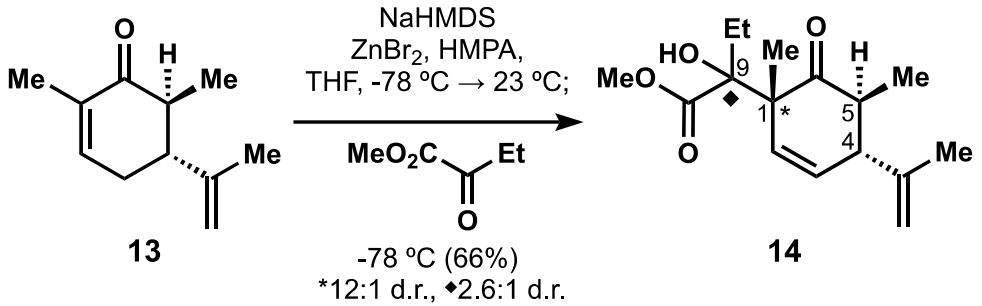

Procedure:

Trans- $\alpha$-methyl-carvone (13) was obtained by chromatographic separation on silica gel with a $5 \% \mathrm{Et}_{2} \mathrm{O} / \mathrm{hexane}$ solvent system after mono-alkylation of $(R)$-carvone according to the procedure described for the synthesis of 4 (see above). HMPA was dried by stirring over anhydrous $\mathrm{CaH}_{2}$ for $>1$ hour and purified via distillation through a simple short path distillation apparatus using a heat gun with mild heating under a vacuum. Zinc bromide was flame-dried on a high vacuum immediately prior to use and used to prepared $15 \mathrm{~mL}$ of a saturated zinc-bromide solution in anhydrous THF under an Argon atmosphere.

To a flame-dried $150 \mathrm{~mL}$ round bottom flask charged with a stir bar under an Argon atmosphere was added anhydrous THF (25 mL), anhydrous HMPA (2.00 mL, $11.5 \mathrm{mmol}, 2.50$ equiv.), and NaHMDS (1M in THF, $6.80 \mathrm{~mL}, 1.50$ equiv.) at $-78{ }^{\circ} \mathrm{C}$ and stirred. To this was added at $-78{ }^{\circ} \mathrm{C}$ a solution of trans- $\alpha$-methyl-carvone (13) $(750 \mathrm{mg}, 4.60 \mathrm{mmol}, 1.00$ equiv.) in anhydrous THF (25 mL). The reaction mixture was then removed from the $-78^{\circ} \mathrm{C}$ acetone/dry ice bath and stirred at room temperature to obtain a clear yellow solution. After $75 \mathrm{~min}$, the solution was cooled back to $-78^{\circ} \mathrm{C}$ and $10 \mathrm{~mL}$ of a saturated $\mathrm{ZnBr}_{2}$ solution in THF was added, causing the solution to become opaque. After stirring for 30 minutes, methyl-2-oxo-butanoate $(1.50 \mathrm{~mL}, 13.8 \mathrm{mmol}, 3.00$ equiv.) was added neat to the solution at $-78^{\circ} \mathrm{C}$ and the reaction was monitored by TLC (20\% EtOAc/hex). Completion of the reaction was indicated by TLC analysis after 45 minutes, at which point the reaction was quenched by addition of a 1:1 mixture of saturated aq. $\mathrm{NH}_{4} \mathrm{Cl}$ and $\mathrm{H}_{2} \mathrm{O}(\sim 50 \mathrm{ml})$ at $-78^{\circ} \mathrm{C}$, diluted with $\mathrm{Et}_{2} \mathrm{O}$ 
$(\sim 20 \mathrm{~mL})$, and warmed to room temperature. The solution was extracted with $\mathrm{Et}_{2} \mathrm{O}(3 \mathrm{x} 50 \mathrm{~mL})$, dried over $\mathrm{MgSO}_{4}$, filtered and concentrated in vacuo. The crude mass ( $3.2 \mathrm{~g}$ ) was purified by flash column chromatography on $400 \mathrm{~g}$ of silica with a solvent gradient of 10\% EtOAc/hex to 35\% EtOAc/hex to obtain 14 (851 mg, 3.04 mmol, $66 \%$ yield) as a $\sim 12: 1$ mixture of diastereomers at $\mathrm{C}-1$ and a 2.6:1 mixture at C-9.

For characterization purposes, the C-9 diastereomers were separated by silica gel-backed prep plate in $20 \%$ EtOAc/hex. The C-1 epimers with the same C-9 stereochemistry co-elute.

Characterization data of aldol addition adduct (14, minor C-9 diastereomer, 1.00:0.04 mix of C-1 epimers):

Description Faint yellow oil

$\underline{R}_{f} 0.48$ in $20 \%$ EtOAc/hex. Weakly UV active. Stain peach in anisaldehyde.

Opt. Rot. Not obtained

${ }^{1}$ H NMR $\quad(600 \mathrm{MHz}$, Chloroform- $d)$; NMR data for major isomer

$\delta 5.69(\mathrm{dd}, J=10.0,2.0 \mathrm{~Hz}, 1 \mathrm{H}), 5.46(\mathrm{dd}, J=10.1,2.7 \mathrm{~Hz}, 1 \mathrm{H}), 4.85(\mathrm{p}, J=1.6 \mathrm{~Hz}, 1 \mathrm{H}), 4.80$

$(\mathrm{d}, J=2.1 \mathrm{~Hz}, 1 \mathrm{H}), 3.80(\mathrm{~s}, 3 \mathrm{H}), 3.46(\mathrm{~d}, J=2.0 \mathrm{~Hz}, 1 \mathrm{H}), 2.96(\mathrm{dq}, J=10.9,6.4 \mathrm{~Hz}, 1 \mathrm{H}), 2.76$

(dt, $J=11.0,2.3 \mathrm{~Hz}, 1 \mathrm{H}), 1.96(\mathrm{dqd}, J=14.4,7.2,2.0 \mathrm{~Hz}, 1 \mathrm{H}), 1.70(\mathrm{t}, J=1.1 \mathrm{~Hz}, 3 \mathrm{H}), 1.55$

(dq, $J=14.5,7.3 \mathrm{~Hz}, 1 \mathrm{H}), 1.15(\mathrm{~s}, 3 \mathrm{H}), 0.96(\mathrm{~d}, J=6.5 \mathrm{~Hz}, 3 \mathrm{H}), 0.81(\mathrm{t}, J=7.3 \mathrm{~Hz}, 3 \mathrm{H})$.

${ }^{13} \mathrm{C}$ NMR $\quad(151 \mathrm{MHz}$, Chloroform- $d$ ); NMR data for major isomer

$\delta 212.8,174.7,145.2,133.0,131.1,113.8,80.9,54.6,53.5,52.8,45.7,26.1,20.4,18.0,11.8$, 8.4 .

$\underline{\text { LRMS }}$ Calculated $\mathrm{C}_{16} \mathrm{H}_{24} \mathrm{O}_{4}: 280.2$ Found: 280.1

$\underline{X-r a y} \quad$ N/A, oil

2D-NMR NOESY

Characterization data of aldol addition adduct (14, major C-9 diastereomer, 1.00:0.12 mix of C-1 epimers):

Description Faint yellow oil

$\underline{R}_{f} \quad 0.39$ in $20 \%$ EtOAc/hex. Weakly UV active. Stain peach in anisaldehyde.

Opt. Rot. Not obtained

${ }^{1} \mathrm{H}$ NMR $\quad(600 \mathrm{MHz}$, Chloroform- $d$ ); NMR data for major isomer

$\delta 5.86(\mathrm{dd}, J=10.2,2.7 \mathrm{~Hz}, 1 \mathrm{H}), 5.68(\mathrm{dd}, J=10.2,1.9 \mathrm{~Hz}, 1 \mathrm{H}), 4.85(\mathrm{p}, J=1.5 \mathrm{~Hz}, 1 \mathrm{H}), 4.81$

$-4.79(\mathrm{~m}, 1 \mathrm{H}), 3.79(\mathrm{~s}, 3 \mathrm{H}), 3.48(\mathrm{~d}, J=0.8 \mathrm{~Hz}, 1 \mathrm{H}), 2.77(\mathrm{dt}, J=11.2,2.3 \mathrm{~Hz}, 1 \mathrm{H}), 2.66(\mathrm{dq}$, $J=11.1,6.4 \mathrm{~Hz}, 1 \mathrm{H}), 1.96(\mathrm{dq}, J=14.3,7.2 \mathrm{~Hz}, 1 \mathrm{H}), 1.75(\mathrm{dq}, J=13.6,7.3 \mathrm{~Hz}, 1 \mathrm{H}), 1.69-$ $1.68(\mathrm{~m}, 3 \mathrm{H}), 1.20(\mathrm{~s}, 3 \mathrm{H}), 0.96(\mathrm{~d}, J=6.5 \mathrm{~Hz}, 3 \mathrm{H}), 0.79(\mathrm{t}, J=7.3 \mathrm{~Hz}, 3 \mathrm{H})$.

${ }^{13} \mathrm{C}$ NMR $\quad(151 \mathrm{MHz}$, Chloroform- $d$ ); NMR data for major isomer $\delta$ 214.0, 175.4 145.2, 131.6, 131.2, 113.8, 81.6, 54.8, 53.0, 51.8, 46.0, 26.6, 20.9, 17.9, 11.8, 8.0.

$\underline{\text { LRMS }}$ Calculated $\mathrm{C}_{16} \mathrm{H}_{24} \mathrm{O}_{4}: 280.2$ Found: 280.1

$\underline{X-\text { ray }} \quad \mathrm{N} / \mathrm{A}$, oil

2D-NMR NOESY 


\subsection{Dehydration of $\mathbf{4}$ to form 5}

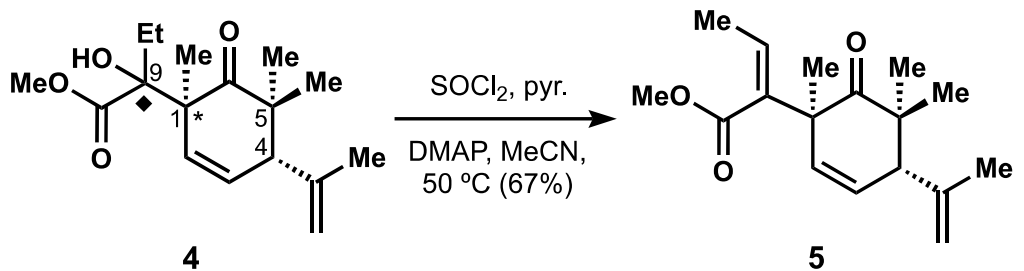

Procedure:

Two separate solutions were made: First, a solution of diastereomeric (3.3:1 d.r.) substrate 4 (1.47 g, 5.0 mmol, 1.0 equiv), DMAP (3.05 g, $25.0 \mathrm{mmol}, 5.0$ equiv), and non-anhydrous $\mathrm{MeCN}(50 \mathrm{~mL},[0.1 \mathrm{M}]$ with respect to substrate) was made in a $250 \mathrm{~mL}$ round bottom flask. Second, a solution of $\mathrm{SOCl}_{2}(725 \mu \mathrm{L}, 10.0 \mathrm{mmol}, 2$ equiv) in anhydrous pyridine $\left(10 \mathrm{~mL},[1 \mathrm{M}]\right.$ with respect to $\left.\mathrm{SOCl}_{2}\right)$ under an argon atmosphere was made. The substrate/DMAP/MeCN solution was slowly added $\mathrm{SOCl}_{2} /$ pyr solution with vigorous stirring at $50^{\circ} \mathrm{C}$ (oil bath). The reaction was monitored by TLC. After 45 minutes, the resulting orange solution was cooled to room temperature, then poured onto a 1:1 mixture of $\mathrm{H}_{2} \mathrm{O}:$ EtOAc $(50 \mathrm{~mL}$ each). The aqueous layer was extracted with EtOAc $(3 \times 50 \mathrm{~mL})$. The combined organic layer was washed with $1 \mathrm{M} \mathrm{HCl}(20 \mathrm{~mL})$, saturated $\mathrm{NaHCO}_{3}(20$ $\mathrm{mL}$ ), and brine. The combined organic layer was dried over $\mathrm{Na}_{2} \mathrm{SO}_{4}$, filtered and concentrated in vacuo. The crude residue was purified by flash column chromatography over silica gel (5\% EtOAc/hex to 10\% EtOAc/hex) to obtain elimination product 5 (926 mg, $3.35 \mathrm{mmol}, 67 \%)$ as a clear yellow oil.

NOTE: Toluene may be substituted for MeCN, but the reaction takes $~ 12$ hours for a similar result.

\section{Characterization data of dehydration product (5):}

Description viscous yellow oil

$\underline{R}_{f} \quad 0.52$ in $10 \%$ EtOAc/hex. UV active. Stains purple in anisaldehyde.

Opt. Rot. $\quad \alpha_{\mathrm{obs}}=-289.5^{\circ}, \mathrm{c}=1.00$ in $\mathrm{CH}_{2} \mathrm{Cl}_{2}, \mathrm{~T}=22.3^{\circ} \mathrm{C}$

1H NMR $(600 \mathrm{MHz}$, Chloroform- $d)$

$\delta 5.84(\mathrm{q}, J=7.1 \mathrm{~Hz}, 1 \mathrm{H}), 5.69(\mathrm{dd}, J=10.1,3.8 \mathrm{~Hz}, 1 \mathrm{H}), 5.66(\mathrm{dd}, J=10.3,0.7 \mathrm{~Hz}, 1 \mathrm{H}), 4.88$ $-4.84(\mathrm{~m}, 1 \mathrm{H}), 4.76-4.72(\mathrm{~m}, 1 \mathrm{H}), 3.72(\mathrm{~s}, 3 \mathrm{H}), 3.08(\mathrm{dd}, J=3.7,0.7 \mathrm{~Hz}, 1 \mathrm{H}), 1.72(\mathrm{~d}, J=$ $7.1 \mathrm{~Hz}, 3 \mathrm{H}), 1.57-1.55(\mathrm{~m}, 3 \mathrm{H}), 1.37$ (s, 3H), $1.22(\mathrm{~s}, 3 \mathrm{H}), 1.00$ (s, 3H).

${ }^{13} \mathrm{C}$ NMR $\quad(151 \mathrm{MHz}$, Chloroform- $d$ )

$\delta 214.5,168.7,144.5,137.3,131.5,129.4,129.0,115.4,57.7,51.6,50.5,47.5,27.6,26.4,22.8$, $21.2,15.5$.

HRMS Calculated $\mathrm{C}_{17} \mathrm{H}_{25} \mathrm{O}_{3}[\mathrm{M}+\mathrm{H}] 277.1804$ | Found: 277.1810

X-ray N/A, oil

2D-NMR NOESY 


\subsection{Intramolecular aldol addition of $\mathbf{5}$ to form $\mathbf{2}$}

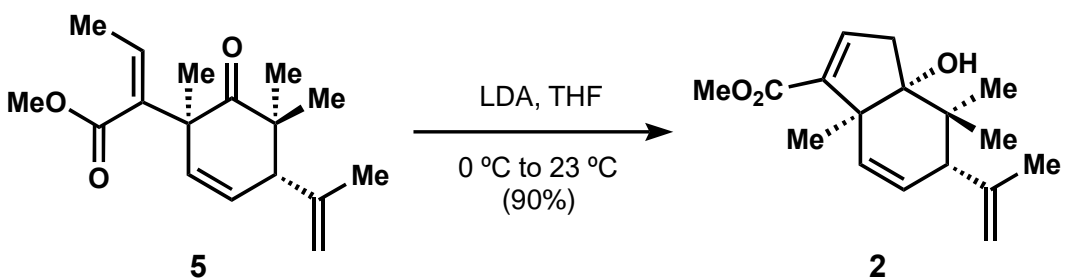

Procedure:

A $[0.5 \mathrm{M}]$ solution of LDA in THF was made by addition of $n \mathrm{BuLi}$ ([2.67M in hex], $12.0 \mathrm{mmol}, 4.5 \mathrm{~mL})$ to a solution of $\mathrm{HN}^{i} \mathrm{Pr}_{2}$ (freshly distilled off $\mathrm{CaH}_{2}, 15.0 \mathrm{mmol}, 2.10 \mathrm{~mL}$ ) in anhydrous THF $(17.4 \mathrm{~mL}$ ) while cooled to $-78^{\circ} \mathrm{C}$ under an argon atmosphere. After addition of $n \mathrm{BuLi}$, the solution was stirred at $0{ }^{\circ} \mathrm{C}$ for 20 minutes, then cooled back to $-78^{\circ} \mathrm{C}$.

A solution of substrate (>99\% purity, $2.49 \mathrm{mmol}, 687 \mathrm{mg}$ ) in anhydrous THF under an argon atmosphere in a flame-dried $100 \mathrm{~mL}$ round bottom flask was cooled to $0^{\circ} \mathrm{C}$. The LDA solution ([0.5M], 1.1 equiv., $5.5 \mathrm{~mL}$ ) was added in a slow but steady stream via syringe to this solution at $0{ }^{\circ} \mathrm{C}$, which caused the solution to turn from clear and pale yellow to clear and orange/red. The solution stirred at $0{ }^{\circ} \mathrm{C}$ for 30 minutes, then warmed to $23^{\circ} \mathrm{C}$ and monitored by TLC (20\% EtOAc/hex, Anis.). Starting material still remained after 3 hours, so $100 \mu \mathrm{L}$ more $[0.5 \mathrm{M}] \mathrm{LDA}$ was added dropwise at $23{ }^{\circ} \mathrm{C}$ to this solution. TLC analysis indicated full consumption of starting material 1 hour after this (4 hours after the initial LDA addition).

The reaction was quenched by addition of $\mathrm{NH}_{4} \mathrm{Cl}$ (aq., saturated, $\left.\sim 20 \mathrm{~mL}\right)$ and dilution with EtOAc $(\sim 20 \mathrm{~mL})$. The reaction was extracted with EtOAc $(3 \mathrm{x} \sim 20 \mathrm{~mL})$. The organic layer was dried over $\mathrm{MgSO}_{4}$, filtered, and concentrated in vacuo. The crude mass $(860 \mathrm{mg})$ was purified on silica gel $(\sim 250 \mathrm{~mL})$ with $2 \mathrm{~L}$ of $10 \%$ EtOAc/hex. The desired compound was isolated as a yellow-white solid. (620 mg, 90\% yield; see NOTE 1).

NOTE 1: The yield drops significantly if the substrate is impure. The excess LDA solution is maintained at -78 ${ }^{\circ} \mathrm{C}$ for the duration of the intramolecular aldol reaction. Use of a larger excess of LDA can lead to transposition of the $\alpha, \beta$-unsaturated ester alkene and incorporation of molecular oxygen, so reaction monitoring by TLC and subsequent addition of small portions of LDA to drive the reaction to completion is preferable to use of more than 1.1 equivalents of LDA at the start of the reaction.

Characterization data of intramolecular aldol product (2):

Description yellow-white solid

$\underline{R}_{f} \quad 0.52$ in $10 \%$ EtOAc/hex. UV active and stains purple in anisaldehyde

Opt. Rot. $\quad \alpha_{\text {obs }}=-27.6^{\circ}, \mathrm{c}=1.00$ in $\mathrm{CH}_{2} \mathrm{Cl}_{2}, \mathrm{~T}=21.0^{\circ} \mathrm{C}$

${ }^{1} \mathrm{H}$ NMR $\quad(600 \mathrm{MHz}$, Chloroform- $d$ )

$\delta 6.67$ (br dd, $J=3.2,2.01 \mathrm{H}$ ), 5.98 (br d, $J=10.3 \mathrm{~Hz}, 1 \mathrm{H}$ ), 5.32 (br d, $J=10.3 \mathrm{~Hz}, 1 \mathrm{H}$ ), 5.02 - 4.99 (br m, 1H), 4.73 (br s, 1H), 3.72 (s, 3H), 2.93 (br s, 1H), 2.92 (br d, $J=18.5 \mathrm{~Hz}, 1 \mathrm{H}$ ), $2.31(\mathrm{dd}, J=18.9,3.2 \mathrm{~Hz}, 1 \mathrm{H}), 1.79(\mathrm{~s}, 3 \mathrm{H}), 1.71(\mathrm{br} \mathrm{s}, 1 \mathrm{H}), 1.42(\mathrm{~s}, 3 \mathrm{H}), 1.06(\mathrm{~s}, 3 \mathrm{H}), 1.00(\mathrm{~s}$, $3 \mathrm{H})$.

${ }^{13} \mathrm{C}$ NMR $(151 \mathrm{MHz}$, Chloroform- $d)$

$\delta$ 165.1, 145.8, 141.0, 140.6, 133.6, 126.7, 116.0, 85.4, 53.3, 52.1, 51.4, 42.6, 40.3, 24.0, 23.3, $18.8,18.5$. 
HRMS Calculated $\mathrm{C}_{17} \mathrm{H}_{25} \mathrm{O}_{3}[\mathrm{M}+\mathrm{H}]: 277.1804$ I Found: 277.1810

X-ray X-ray quality crystals were grown by slow evaporation of hexanes layered on a $\mathrm{CDCl}_{3}$ solution of 2 in a cylindrical recrystallization tube $(\sim 500 \mu \mathrm{L}$ volume $)$ placed vertically within a $20 \mathrm{~mL}$ scintillation vial and capped with aluminum foil.

\section{$\underline{3.6 \text { Bromoetherification of } \mathbf{2} \text { to form } \mathbf{6}}$}

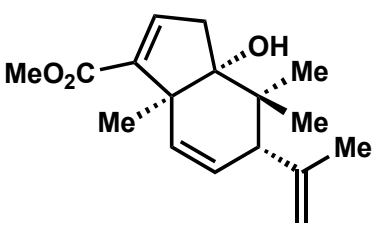

2

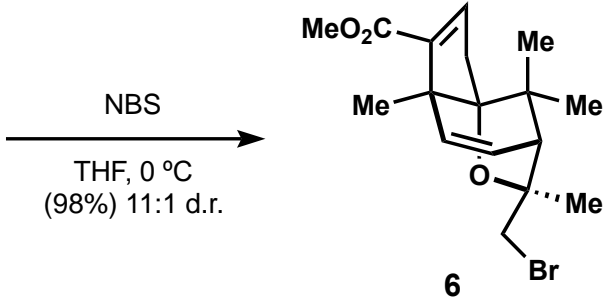

Procedure:

A flame-dried $50 \mathrm{~mL}$ round bottom flask was charged with solid triene substrate 2 (1.0 equiv, $610 \mathrm{mg}, 2.21$ mmol) and a stir bar and placed under an argon atmosphere at $0{ }^{\circ} \mathrm{C}$ in an ice-water bath. A separate flame-dried $50 \mathrm{~mL}$ round bottom flask was charged with NBS (recrystallized, 2.0 equiv, $4.42 \mathrm{mmol}, 787 \mathrm{mg}$ ) and anhydrous THF ([0.2 M], wrt NBS) at $0{ }^{\circ} \mathrm{C}$ in an ice-water bath and kept out of light (wrapped in foil and hood light turned off). Without stirring (See NOTE 1), the NBS/THF solution was then transferred by cannula (see NOTE 2) with differential pressure under an Argon atmosphere at $0{ }^{\circ} \mathrm{C}$. The solution after transfer was clear and pale yellow. The reaction was stirred at $0{ }^{\circ} \mathrm{C}$ in the dark (fume hood lights off and the reaction flask was wrapped in foil) and monitored by TLC (15\% EtOAc/hex, Anis.). No starting material remained after 2 hours.

The reaction was worked-up by addition to a mixture of $\mathrm{NH}_{4} \mathrm{Cl}$ (saturated, aq., $\left.\sim 50 \mathrm{~mL}\right)$ and EtOAc $(\sim 50 \mathrm{~mL})$. The aqueous layer was extracted with EtOAc $(3 \mathrm{x} \sim 100 \mathrm{~mL})$ and then washed with $\mathrm{NaHCO}_{3}$ (saturated, $1 \mathrm{x} \sim 50$ $\mathrm{mL}$ ). The organic layer was dried over $\mathrm{MgSO}_{4}$, filtered, and concentrated in vacuo. The crude mass ( 1.2 g) was dry-loaded with celite onto a silica column $(\sim 100 \mathrm{~mL}$ of silica) and purified by flash column chromatography with 15\% EtOAc/hex. The desired compound was isolated as a yellow-tinged white solid. (776 mg, $98 \%$ yield, 11:1 diastereoselectivity in favor of the endo diastereomer shown above.). Isolated yields for this reaction ranged between $92-98 \%$ for different runs.

NOTE 1: Dissolution of the substrate in THF prior to addition of the NBS/THF solution diminishes the diastereoselectivity of the reaction. Although the diastereoselectivity of this step is technically inconsequential because the stereocenter is erased by the final zinc reduction step, low diastereoselectivity at this step complicates analysis and characterization of the products of subsequent steps.

NOTE 2: The cannula was cooled during transfer by contact with solid dry ice.

\section{Characterization data of bromoetherification product (major diastereomer) (6):}

Description yellow-white powder. Can be obtained as white crystalline material by recrystallization

$\underline{R}_{f} \quad 0.37$ in $10 \% \mathrm{EtOAc/hx}$. UV active and stains purple in anisaldehyde

Opt. Rot. $\quad \alpha_{\mathrm{obs}}=-14.7^{\circ}, \mathrm{c}=1.00$ in $\mathrm{CH}_{2} \mathrm{Cl}_{2}, \mathrm{~T}=21.5^{\circ} \mathrm{C}$ (on $11: 1$ diastereomeric mixture)

${ }^{1} \mathrm{H} \mathrm{NMR} \quad(600 \mathrm{MHz}$, Chloroform- $d)$ 
$\delta 6.53(\mathrm{dd}, J=3.5,2.2 \mathrm{~Hz}, 1 \mathrm{H}), 6.25(\mathrm{~d}, J=9.6 \mathrm{~Hz}, 1 \mathrm{H}), 5.97(\mathrm{dd}, J=9.6,6.9 \mathrm{~Hz}, 1 \mathrm{H}), 3.72$ (s, 3H), 3.66 (dd, $J=9.2,1.1 \mathrm{~Hz}, 1 \mathrm{H}), 3.40(\mathrm{~d}, J=9.2 \mathrm{~Hz}, 1 \mathrm{H}), 2.59$ (ddd, $J=18.1,2.2,0.7$ $\mathrm{Hz}, 1 \mathrm{H}), 2.46$ (ddd, $J=18.2,3.6,0.8 \mathrm{~Hz}, 1 \mathrm{H}), 2.21(\mathrm{~d}, J=6.9 \mathrm{~Hz}, 1 \mathrm{H}), 1.65$ (d, $J=1.0 \mathrm{~Hz}$, $3 \mathrm{H}), 1.29$ (s, 3H), 1.23 (s, 3H), 0.98 (s, 3H).

${ }^{13} \mathrm{C}$ NMR $\quad(151 \mathrm{MHz}$, Chloroform- $d$ )

$\delta 164.3,142.7,139.1,132.7,128.0,95.9,85.2,52.9,52.8,51.4,46.2,42.9,32.1,27.2,27.0$, 26.2, 20.6 .

$\underline{\text { HRMS }}$ Calculated $\mathrm{C}_{17} \mathrm{H}_{24} \mathrm{BrO}_{3}[\mathrm{M}+\mathrm{H}] 355.0909$ I Found: 355.0907

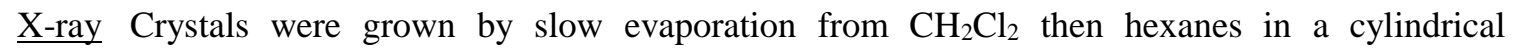
recrystallization $(\sim 500 \mu \mathrm{L}$ volume) placed vertically within a $20 \mathrm{~mL}$ scintillation vial and capped with aluminum foil at room temperature. The starting material was a 7.25:1.00 diastereomeric mixture.

\subsection{Epoxidation of 6 to form 7}

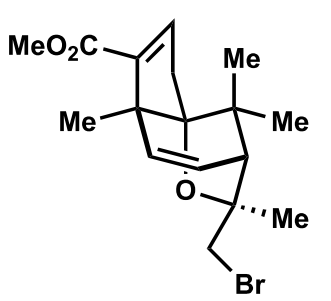

6

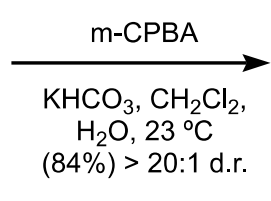

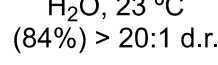

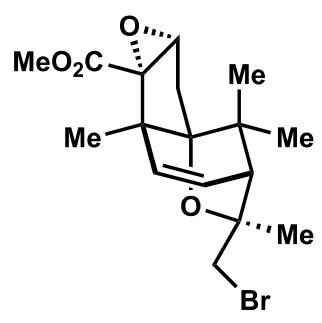

7

Procedure:

To a suspension of substrate 6 ( $2.5 \mathrm{~g}, 7.0 \mathrm{mmol}, 1$ equiv) in $\mathrm{CH}_{2} \mathrm{Cl}_{2} / \mathrm{H}_{2} \mathrm{O}(5: 1$, v:v, $120 \mathrm{~mL})$ was added $\mathrm{KHCO}_{3}$ (5.6 g, $56.0 \mathrm{mmol}, 8$ equiv) and stirred vigorously for $15 \mathrm{~min}$. The biphasic reaction mixture was then cooled to $0{ }^{\circ} \mathrm{C}$ and $\mathrm{mCPBA}$ (50\% purity, $9.66 \mathrm{~g}, 28.0 \mathrm{mmol}, 4$ equiv) was slowly added portion-wise. The solution was stirred vigorously for 2 hours at room temperature, during which time a white precipitate formed. TLC indicated starting material consumption. The reaction was quenched by slowly adding a saturated $\mathrm{Na}_{2} \mathrm{~S}_{2} \mathrm{O}_{3}$ solution (aq., $20 \mathrm{~mL})$ at $0^{\circ} \mathrm{C}$, then diluted by $\mathrm{H}_{2} \mathrm{O}(100 \mathrm{~mL})$ and $\mathrm{CH}_{2} \mathrm{Cl}_{2}(200 \mathrm{~mL})$. The aqueous layer was extracted with $\mathrm{CH}_{2} \mathrm{Cl}_{2}$ (3 x $100 \mathrm{~mL}$ ). The combined organics were dried over $\mathrm{Na}_{2} \mathrm{SO}_{4}$, filtered, and concentrated in vacuo. The crude product was purified by column chromatography over silica gel (5\% EtOAc/Hexane) to afford epoxide 7 $(2.18 \mathrm{~g}, 5.88 \mathrm{mmol}, 84 \%)$ as a single diastereomer.

\section{Characterization data of epoxidation product (7):}

Description yellow-white powder. Can be obtained as white crystalline material by recrystallization

$\underline{R}_{f} 0.28$ in $10 \%$ EtOAc/hex. Stains purple in anisaldehyde.

Opt. Rot. $\quad \alpha_{\text {obs }}=-36.0^{\circ}, \mathrm{c}=1.00$ in $\mathrm{CH}_{2} \mathrm{Cl}_{2}, \mathrm{~T}=22.0^{\circ} \mathrm{C}$

${ }^{1} \mathrm{H}$ NMR $\quad(600 \mathrm{MHz}$, Chloroform- $d)$

$\delta 6.20(\mathrm{dd}, J=9.6,0.7 \mathrm{~Hz}, 1 \mathrm{H}), 6.02(\mathrm{dd}, J=9.6,6.9 \mathrm{~Hz}, 1 \mathrm{H}), 3.75(\mathrm{dd}, J=4.1,1.0 \mathrm{~Hz}, 1 \mathrm{H})$, $3.71(\mathrm{~s}, 3 \mathrm{H}), 3.60(\mathrm{dd}, J=9.2,1.1 \mathrm{~Hz}, 1 \mathrm{H}), 3.31(\mathrm{~d}, J=9.2 \mathrm{~Hz}, 1 \mathrm{H}), 2.23(\mathrm{~d}, J=6.9 \mathrm{~Hz}, 1 \mathrm{H})$, 2.12 (ddd, $J=14.6,4.2,0.9 \mathrm{~Hz}, 1 \mathrm{H}), 1.84$ (dt, $J=14.6,1.0 \mathrm{~Hz}, 1 \mathrm{H}), 1.61$ (d, $J=1.1 \mathrm{~Hz}, 3 \mathrm{H})$, $1.29(\mathrm{~s}, 4 \mathrm{H}), 1.16(\mathrm{~s}, 3 \mathrm{H}), 1.14(\mathrm{~s}, 3 \mathrm{H})$.

${ }^{13} \mathrm{C}$ NMR $\quad(151 \mathrm{MHz}$, Chloroform- $d$ ) 
$\delta$ 168.1, 133.1, 127.6, 99.4, 85.9, 66.0, 61.5, 52.5, 52.0 (observed by HSQC), 48.2, 46.6, 42.6, 29.3, 28.1, 26.2, 24.2, 17.1.

$\underline{\text { HRMS }}$ Calculated $\mathrm{C}_{17} \mathrm{H}_{24} \mathrm{BrO}_{4}[\mathrm{M}+\mathrm{H}]: 371.0858$ Found: 371.0856

X-ray Crystals were grown by slow evaporation at room temperature of a solution of $\mathbf{7}$ in hexanes from a cylindrical glass tube $(\sim 500 \mu \mathrm{L}$ volume $)$ placed vertically within a $20 \mathrm{~mL}$ glass vial capped with aluminum foil.

\subsection{Dihydroxylation of $\mathbf{7}$ to form $\mathbf{8}$}
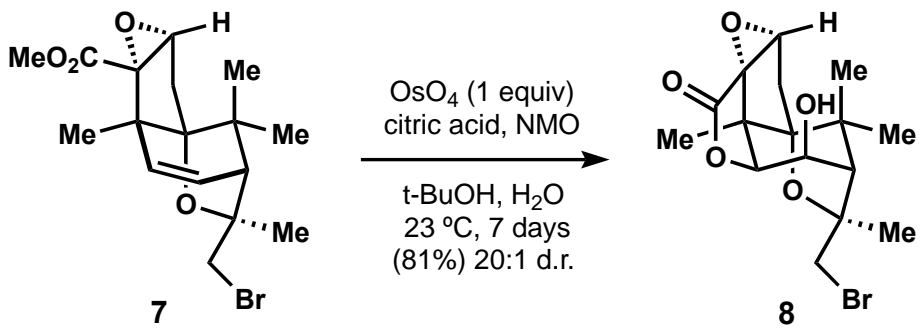

Procedure:

A $1 \mathrm{~L}$ round bottom flask was charged with a magnetic stir bar, the alkene substrate $7(3.31 \mathrm{~g}, 8.92 \mathrm{mmol}, 1$ equiv), citric acid (3.43 g, $17.84 \mathrm{mmol}, 2$ equiv), $\mathrm{NMO}$ (3.13 g, $26.76 \mathrm{mmol}, 3$ equiv), and $t$-BuOH (57 mL). During this time, the fume hood lights were turned off and the reaction was wrapped with aluminum foil to minimize exposure to ambient light. $\mathrm{OsO}_{4}\left(57 \mathrm{~mL}, 4 \mathrm{wt} \%\right.$ in $\mathrm{H}_{2} \mathrm{O}, 9.37 \mathrm{mmol}, 1.05$ equiv, NOTE 1$)$ was then added at room temperature in the dark. The reaction was capped with a yellow cap (a 24/40 polyethylene flask stopper), sealed with duct tape, and stirred vigorously (>1000 rpm) for 7 days at room temperature. During the course of the reaction, the yellow cap was stained black by osmium tetroxide. The reaction was quenched by adding a saturated solution of $\mathrm{Na}_{2} \mathrm{~S}_{2} \mathrm{O}_{3}(20 \mathrm{~mL})$ after cooling the reaction to $0{ }^{\circ} \mathrm{C}$. After stirring for $15 \mathrm{~min}$, the dark yellow solution changed to black suspension, hood lamps were turned on, the reaction mixture was diluted with EtOAc $(200 \mathrm{~mL})$, then extracted with EtOAc $(3 \times 300 \mathrm{~mL})$. The combined organic layer was dried over $\mathrm{Na}_{2} \mathrm{SO}_{4}$, filtered, and concentrated in vacuo. The crude mixture was purified by column chromatography over silica gel (30\% EtOAc/Hexane to 50\% EtOAc/Hexane) to afford desired dihydroxylation product 8 (2.7 g, 7.23 mmol, 81\%, 89\% brsm) as single diastereoisomer. Starting material 7 (298 mg, $0.8 \mathrm{mmol}, 9 \%$ ) was recovered.

NOTE 1: $\mathrm{OsO}_{4} 4 \mathrm{wt} \%$ in $\mathrm{H}_{2} \mathrm{O}$ is a commercially available greenish solution. It may also be made from $\mathrm{OsO}_{4}$ solid in deionized $\mathrm{H}_{2} \mathrm{O}$. $\mathrm{OsO}_{4}$ is a highly toxic volatile solid so use of an efficient fume hood is strongly recommended for this procedure.

\section{Characterization data of dihydroxylation product (8):}

Description white foam/powder

$\underline{R}_{f} \quad 0.41$ in $50 \%$ EtOAc/Hex. Anis. Stains dark blue/purple.

Opt. Rot. $\quad \alpha_{\text {obs }}=2.4^{\circ}, \mathrm{c}=1.00$ in $\mathrm{CH}_{2} \mathrm{Cl}_{2}, \mathrm{~T}=20.7^{\circ} \mathrm{C}$

${ }^{1} \mathrm{H}$ NMR $\quad(600 \mathrm{MHz}$, Chloroform- $d$ )

$\delta 4.78(\mathrm{~d}, J=8.8 \mathrm{~Hz}, 1 \mathrm{H}), 4.70(\mathrm{ddd}, J=8.9,3.5,1.5 \mathrm{~Hz}, 1 \mathrm{H}), 3.89(\mathrm{dd}, J=3.9,1.6 \mathrm{~Hz}, 1 \mathrm{H})$, $3.35(\mathrm{~d}, J=10.4 \mathrm{~Hz}, 1 \mathrm{H}), 3.28(\mathrm{~d}, J=10.4 \mathrm{~Hz}, 1 \mathrm{H}), 2.23(\mathrm{dd}, J=14.6,3.9 \mathrm{~Hz}), 2.24-2.21$ $(\mathrm{m}, 2 \mathrm{H}), 1.96(\mathrm{ddd}, J=14.6,1.6,0.9 \mathrm{~Hz}, 1 \mathrm{H}), 1.65(\mathrm{~s}, 3 \mathrm{H}), 1.31(\mathrm{~s}, 3 \mathrm{H}), 1.25(\mathrm{~s}, 3 \mathrm{H}), 1.23(\mathrm{~s}$, $3 \mathrm{H})$. 
${ }^{13} \mathrm{C}$ NMR $\quad(151 \mathrm{MHz}$, Chloroform- $d)$

$\delta$ 170.7, 100.6, 82.4, 79.4, 68.4, 67.7, 63.1, 56.9, 44.3, 44.1, 40.9, 31.8, 29.8, 27.5, 22.7, 18.7.

$\underline{\operatorname{HRMS}(\mathrm{M}+\mathrm{H})}$ Calculated $\mathrm{C}_{16} \mathrm{H}_{22} \mathrm{BrO}_{5}[\mathrm{M}+\mathrm{H}]: 373.0651$ Found: 373.0646

$\underline{\mathrm{X} \text {-ray }}$ Crystals were grown by slow evaporation from hexanes/EtOAc $(5: 1)$ in a $5 \mathrm{~mL}$ vial covered with Teflon tape at room temperature.

\subsection{Oxidation of $\mathbf{8}$ to $\mathbf{1 8}$}

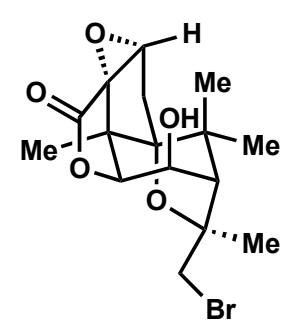

8

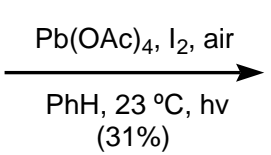

$(31 \%)$

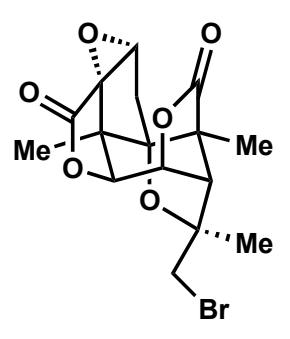

18

Procedure:

To a solution of $\mathrm{Pb}(\mathrm{OAc})_{4}(592 \mathrm{mg}, 1.34 \mathrm{mmol}, 5$ equiv, NOTE 1$)$ in benzene $(10 \mathrm{~mL})$ was added $\mathrm{I}_{2}(340 \mathrm{mg}$, $1.34 \mathrm{mmol}, 5$ equiv) in the dark (covered with aluminum foil and hood light turned-off) at room temperature and stirred for $30 \mathrm{~min}$. To a suspension of 8 (100 mg, $0.27 \mathrm{mmol}, 1$ equiv) and $\mathrm{CaCO}_{3}(270 \mathrm{mg}, 2.7 \mathrm{mmol}, 10$ equiv) in benzene $(5 \mathrm{~mL})$ was added the $\mathrm{Pb}(\mathrm{OAc})_{4} / \mathrm{I}_{2} /$ benzene solution at room temperature. The hood lamps were turned on and the reaction was vigorously stirred at room temperature under ambient light for $2.5 \mathrm{~h}$. Consumption of 8 was monitored by TLC. The reaction was quenched by saturated $\mathrm{Na}_{2} \mathrm{~S}_{2} \mathrm{O}_{3}(5 \mathrm{~mL})$ at $0{ }^{\circ} \mathrm{C}$ then filtered through a short pad of Celite, washed with EtOAc $(3 \times 10 \mathrm{~mL})$. The combined organic layer was dried over $\mathrm{Na}_{2} \mathrm{SO}_{4}$, filtered, and concentrated in vacuo. The crude product was purified by column chromatography over silica gel (50\% EtOAc/Hexane) to afford 5-methyl-bromopicrotoxinin 18 (32 mg, $0.084 \mathrm{mmol}, 31 \%)$ as a white solid.

NOTE 1: Commercially available $\mathrm{Pb}(\mathrm{OAc})_{4}$ is stabilized with $\mathrm{AcOH}$, pure $\mathrm{Pb}(\mathrm{OAc})_{4}$ could be freshly recrystallized from $\mathrm{AcOH}$, then washed three times with hexane prior to use.

\section{Characterization data of oxidation product (18):}

Description clear to white amphorous solid

$\underline{R}_{f} \quad 0.51$ in $50 \%$ EtOAc/hex. Stains weakly grey/green in anisaldehyde.

Opt. Rot. $\quad \alpha_{\mathrm{obs}}=-17.0^{\circ}, \mathrm{c}=0.50$ in $\mathrm{CH}_{2} \mathrm{Cl}_{2}, \mathrm{~T}=20.0^{\circ} \mathrm{C}$

1 $\mathrm{H} \mathrm{NMR} \quad(600 \mathrm{MHz}$, Chloroform- $d)$

$\delta 5.22(\mathrm{t}, J=5.3 \mathrm{~Hz}, 1 \mathrm{H}), 4.76(\mathrm{~d}, J=5.2 \mathrm{~Hz}, 1 \mathrm{H}), 3.96(\mathrm{dd}, J=3.6,1.5 \mathrm{~Hz}, 1 \mathrm{H}), 3.52(\mathrm{dd}, J$ $=10.6,1.2 \mathrm{~Hz}, 1 \mathrm{H}), 3.41(\mathrm{~d}, J=10.7 \mathrm{~Hz}, 1 \mathrm{H}), 3.16(\mathrm{dd}, J=5.5,0.9 \mathrm{~Hz}, 1 \mathrm{H}), 2.46(\mathrm{dd}, J=$ 14.4, 3.6 Hz, 1H), $1.94(\mathrm{dt}, J=14.4,1.3 \mathrm{~Hz}, 1 \mathrm{H}), 1.61(\mathrm{~d}, J=1.0 \mathrm{~Hz}, 3 \mathrm{H}), 1.56(\mathrm{~s}, 3 \mathrm{H}), 1.36$ (s, 3H).

${ }^{13} \mathrm{C} \mathrm{NMR} \quad(151 \mathrm{MHz}$, Chloroform- $d$ )

$\delta$ 173.6, 168.3, 97.3, 84.2, 78.3, 75.8, 67.7, 63.3, 60.5, 53.9, 47.8, 36.8, 33.9, 26.5, 19.7, 17.4.

$\underline{\text { HRMS }}$ Calculated $\mathrm{C}_{16} \mathrm{H}_{18} \mathrm{BrO}_{6}[\mathrm{M}+\mathrm{H}]: 385.0287$ Found: 385.0279 
X-ray Crystals were grown by slow evaporation from hexanes $/ \mathrm{CH}_{2} \mathrm{Cl}_{2}(1: 1)$ in a $5 \mathrm{~mL}$ vial covered with Teflon tape at room temperature.

$\underline{3.10 \text { Reductive debromination of } \mathbf{1 8} \text { to form 5-methyl-picrotoxinin (20) }}$

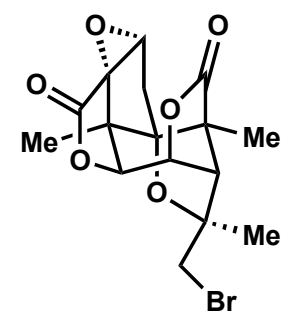

18

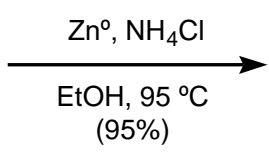

$(95 \%)$

Procedure:

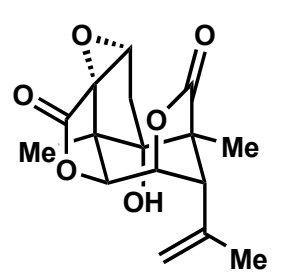

20

Zinc powder (55 mg, $0.84 \mathrm{mmol}, 10$ equiv), $\mathrm{NH}_{4} \mathrm{Cl}$ ( $90 \mathrm{mg}, 1.68 \mathrm{mmol}, 20$ equiv) were added into a solution of 5-methyl-bromopicrotoxinin 18 (32 mg, $0.084 \mathrm{mmol}, 1$ equiv) in EtOH/ $\mathrm{H}_{2} \mathrm{O}$ (v:v, 10:1, $6.6 \mathrm{~mL}$ ). Then the reaction was warmed up to $95{ }^{\circ} \mathrm{C}$ and stirred at this temperature for $2 \mathrm{~h}$. The reaction mixture was diluted by EtOAc $(5 \mathrm{~mL})$ then filtered through a short pad of Celite and washed with EtOAc $(3 \times 3 \mathrm{~mL})$. The reaction mixture was concentrated and purified by column chromatography over silica gel $\left(10 \% \mathrm{EtOAc} / \mathrm{CH}_{2} \mathrm{Cl}_{2}\right)$ to give 5-methyl-picrotoxinin 20 ( $24.4 \mathrm{mg}, 0.08 \mathrm{mmol}, 95 \%)$ as a white solid.

Characterization data of 5-methyl-picrotoxinin (20):

Description white crystalline solid

$\underline{R}_{f} \quad 0.31$ in $40 \%$ EtOAc/hex. Stains brown in anisaldehyde.

Opt. Rot. $\quad \alpha_{\mathrm{obs}}=-1.2^{\circ}, \mathrm{c}=0.10$ in $\mathrm{CH}_{2} \mathrm{Cl}_{2}, \mathrm{~T}=20.0^{\circ} \mathrm{C}$

1H NMR $(600 \mathrm{MHz}$, Chloroform- $d)$

$\delta 5.11(\mathrm{p}, J=1.6 \mathrm{~Hz}, 1 \mathrm{H}), 5.05(\mathrm{~d}, J=2.1 \mathrm{~Hz}, 1 \mathrm{H}), 5.02(\mathrm{dd}, J=5.2,3.4 \mathrm{~Hz}, 1 \mathrm{H}), 4.83(\mathrm{~d}, J$

$=3.4 \mathrm{~Hz}, 1 \mathrm{H}), 3.70(\mathrm{dd}, J=3.6,0.7 \mathrm{~Hz}, 1 \mathrm{H}), 3.14(\mathrm{~d}, J=5.1 \mathrm{~Hz}, 1 \mathrm{H}), 2.97(\mathrm{dd}, J=15.3,3.6$

$\mathrm{Hz}, 1 \mathrm{H}), 1.96(\mathrm{dt}, J=1.6,0.9 \mathrm{~Hz}, 3 \mathrm{H}), 1.88(\mathrm{~s}, 1 \mathrm{H}), 1.75(\mathrm{~d}, J=15.3 \mathrm{~Hz}, 1 \mathrm{H}), 1.53(\mathrm{~s}, 3 \mathrm{H})$, $1.26(\mathrm{~s}, 3 \mathrm{H})$.

${ }^{13} \mathrm{C}$ NMR $\quad(151 \mathrm{MHz}$, Chloroform- $d$ )

$\delta$ 177.2, 168.9, 139.4, 115.6, 88.7, 80.2, 76.1, 72.6, 62.0, 53.9, 51.0, 47.4, 42.5, 24.3, 17.1, 17.0.

HRMS Calculated $\mathrm{C}_{16} \mathrm{H}_{19} \mathrm{O}_{6}[\mathrm{M}+\mathrm{H}]: 307.1182$ | Found: 307.1178

X-ray Crystals were grown by slow evaporation of a solution of $\mathbf{2 0}$ in $\mathrm{CDCl}_{3}$ in a small cylindrical glass recrystallization tube $(\sim 500 \mu \mathrm{L}$ volume $)$ placed vertically within a $20 \mathrm{~mL}$ scintillation vial and capped with aluminum foil at room temperature.

\section{$\underline{3.11 \text { Etherification of } \mathbf{8} \text { to form } \mathbf{9}}$}




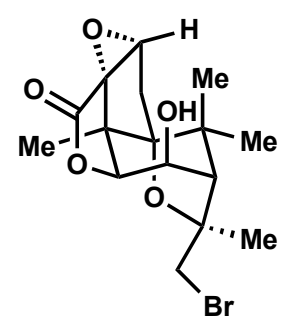

8
(1)

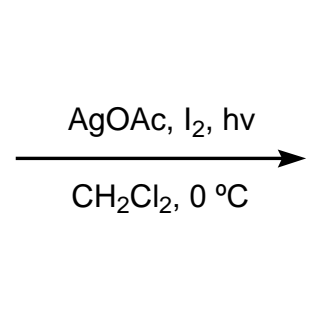

Procedure:

Two reactions were carried out in parallel. To a suspension of alcohol 8 ( $2 \times(50 \mathrm{mg}, 0.13 \mathrm{mmol}, 1$ equiv $))$ and $\operatorname{AgOAc}(2 \times$ ( $109 \mathrm{mg}, 0.65 \mathrm{mmol}, 5$ equiv) $)$ in $\mathrm{CH}_{2} \mathrm{Cl}_{2}(2 \times 5 \mathrm{~mL})$ was added $\mathrm{I}_{2}(2 \times$ (165 mg, $0.65 \mathrm{mmol}, 5$ equiv) as solid at $0^{\circ} \mathrm{C}$. The reaction was vigorously stirred under ambient light for 1 hour, then quenched with saturated $\mathrm{Na}_{2} \mathrm{~S}_{2} \mathrm{O}_{3}$ (aq., $0.5 \mathrm{~mL}$ each) at $0{ }^{\circ} \mathrm{C}$. The two reactions were combined, filtered through a short pad of celite and washed with $\mathrm{CH}_{2} \mathrm{Cl}_{2}(3 \times 10 \mathrm{~mL})$. The crude product was concentrated in vacuo and then purified by column chromatography over silica gel (5\% $\mathrm{EtOAc} / \mathrm{CH}_{2} \mathrm{Cl}_{2}$ to $\left.10 \% \mathrm{EtOAc} / \mathrm{CH}_{2} \mathrm{Cl}_{2}\right)$ to give ether $9(49 \mathrm{mg}, 0.13$ $\mathrm{mmol}, 51 \%)$ as colorless foam and the major byproduct, ketone 15 (17 mg, $0.047 \mathrm{mmol}, 18 \%)$, as pale yellow solid.

Characterization data of ether 9:

Description colorless oil/foam

$\underline{R}_{f} \quad 0.51$ in $10 \% \mathrm{EtOAc} / \mathrm{CH}_{2} \mathrm{Cl}_{2}$. Stains dark blue in anisaldehyde.

Opt. Rot. $\alpha_{\text {obs }}=-64.3^{\circ}, \mathrm{c}=2.00$ in $\mathrm{CH}_{2} \mathrm{Cl}_{2}, \mathrm{~T}=20.0^{\circ} \mathrm{C}$

$\underline{{ }^{1} \mathrm{H} \mathrm{NMR}} \quad\left(600 \mathrm{MHz}, \mathrm{CDCl}_{3}\right)$

$\delta 4.75(\mathrm{dd}, J=5.8 \mathrm{~Hz}, J=4.9 \mathrm{~Hz}, 1 \mathrm{H}), 4.63(\mathrm{~d}, J=5.8 \mathrm{~Hz}, 1 \mathrm{H}), 4.02(\mathrm{~d}, J=11.1 \mathrm{~Hz}, 1 \mathrm{H}), 3.93$ $(\mathrm{dd}, J=3.8,1.5 \mathrm{~Hz}, 1 \mathrm{H}), 3.71(\mathrm{~d}, J=11.1 \mathrm{~Hz}, 1 \mathrm{H}), 3.42(\mathrm{~d}, J=10.7 \mathrm{~Hz}, 1 \mathrm{H}), 3.34(\mathrm{~d}, J=10.7$ $\mathrm{Hz}, 1 \mathrm{H}), 2.68(\mathrm{~d}, J=4.9 \mathrm{~Hz}, 1 \mathrm{H}), 2.32(\mathrm{dd}, J=14.6,3.8 \mathrm{~Hz}, 1 \mathrm{H}), 1.99(\mathrm{~d}, J=14.6 \mathrm{~Hz}, 1 \mathrm{H})$, $1.59(\mathrm{~s}, 3 \mathrm{H}), 1.38(\mathrm{~s}, 3 \mathrm{H}), 1.31(\mathrm{~s}, 3 \mathrm{H})$.

${ }^{13} \mathrm{C} \mathrm{NMR} \quad\left(150 \mathrm{MHz}, \mathrm{CDCl}_{3}\right)$

$\delta$ 169.8, 100.1, 81.8, 81.6, 77.0 (overlaps with $\mathrm{CDCl}_{3}$ ), 71.8, 69.0, 62.4, 60.6, 54.7, 46.1, 38.7, 33.5, 26.7, 21.6, 18.1 .

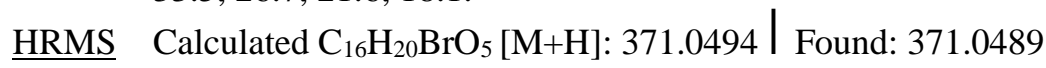

X-ray not obtained

Characterization data of ketone 15 :

Description pale yellow solid

$\underline{R}_{f} \quad 0.57$ in $5 \% \mathrm{EtOAc} / \mathrm{CH}_{2} \mathrm{Cl}_{2}$. Stains blue in anisaldehyde.

Opt. Rot. $\alpha_{\text {obs }}=-43.0^{\circ}, \mathrm{c}=0.50$ in $\mathrm{CH}_{2} \mathrm{Cl}_{2}, \mathrm{~T}=20.0^{\circ} \mathrm{C}$

$\underline{{ }^{1} \mathrm{H} \mathrm{NMR}} \quad\left(600 \mathrm{MHz}, \mathrm{CDCl}_{3}\right)$

$\delta 4.51(\mathrm{~s}, 1 \mathrm{H}), 3.94(\mathrm{dd}, J=3.8,1.6 \mathrm{~Hz}, 1 \mathrm{H}), 3.27(\mathrm{~d}, J=11.0 \mathrm{~Hz}, 1 \mathrm{H}), 3.22(\mathrm{~d}, J=11.0 \mathrm{~Hz}$, $1 \mathrm{H}), 2.84(\mathrm{~s}, 1 \mathrm{H}), 2.34$ (dd, $J=14.7,3.8 \mathrm{~Hz}, 1 \mathrm{H}), 2.12$ (ddd, $J=14.7,1.6,0.9 \mathrm{~Hz}, 1 \mathrm{H}), 1.62$ (s, 3H), $1.41(\mathrm{~s}, 3 \mathrm{H}), 1.38(\mathrm{~s}, 3 \mathrm{H}), 1.13(\mathrm{~s}, 3 \mathrm{H})$.

${ }^{13} \mathrm{C} \mathrm{NMR} \quad\left(150 \mathrm{MHz}, \mathrm{CDCl}_{3}\right)$

$\delta$ 202.3, 169.4, 100.6, 82.8, 81.6, 69.4, 68.1, 63.0, 47.6, 45.2, 39.3, 32.1, 28.7, 26.8, 21.7, 18.1 .

HRMS Calculated $\mathrm{C}_{16} \mathrm{H}_{20} \mathrm{BrO}_{5}[\mathrm{M}+\mathrm{H}]: 371.0494$ I Found: 371.0491 . 
$\underline{\mathrm{X} \text {-ray }}$ Crystals were grown by slow evaporation from $\mathrm{CH}_{2} \mathrm{Cl}_{2}$ in a $5 \mathrm{~mL}$ vial covered with Teflon tape at room temperature.

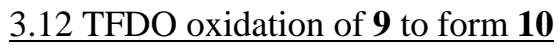

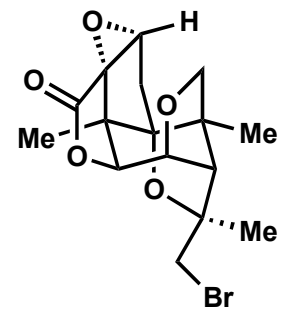

9

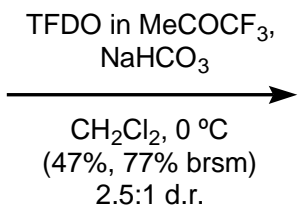

2.5:1 d.r.

Procedure:

To a $20 \mathrm{~mL}$ vial was charged ether 9 (60 mg, $0.16 \mathrm{mmol}, 1$ equiv) and $\mathrm{NaHCO}_{3}(59 \mathrm{mg}, 0.7 \mathrm{mmol}, 4.4$ equiv) in $\mathrm{CH}_{2} \mathrm{Cl}_{2}(1.5 \mathrm{~mL})$. During this time, the fume hood lights were turned off and the reaction was wrapped with aluminum foil to minimize exposure to ambient light. A TFDO solution ( $\sim .5 \mathrm{M}$ in 1,1,1-trifluoroacetone, $3 \mathrm{~mL}$, $1.5 \mathrm{mmol}, 9.4$ equiv, NOTE 1) was added dropwise at $0{ }^{\circ} \mathrm{C}$. The reaction was vigorously stirred for $6 \mathrm{~h}$ in the dark, then quenched with saturated $\mathrm{Na}_{2} \mathrm{~S}_{2} \mathrm{O}_{3}(0.5 \mathrm{~mL})$ at $0{ }^{\circ} \mathrm{C}$. The mixture was warmed up slowly to room temperature and filtered through a short pad of Celite and washed with $\mathrm{CH}_{2} \mathrm{Cl}_{2}(2 \times 10 \mathrm{~mL})$. The crude product was concentrated in vacuo and then purified by column chromatography over silica gel $\left(10 \% \mathrm{EtOAc} / \mathrm{CH}_{2} \mathrm{Cl}_{2}\right.$ to $\left.30 \% \mathrm{EtOAc} / \mathrm{CH}_{2} \mathrm{Cl}_{2}\right)$. The desired lactol $10(29 \mathrm{mg}, 0.075 \mathrm{mmol}, 47 \%, 77 \% \mathrm{brsm})$ was obtained as a colorless oil diastereomer mixture (dr 2.5:1), 9 (23.8 $\mathrm{mg}, 0.064 \mathrm{mmol}, 40 \%)$ was recovered (NOTE 2).

NOTE 1: A methyl(trifluoromethyl)dioxirane (TFDO) solution in trifluoroacetone was prepared according to Tetrahedron 1996, 52, 2377-2384 or Baran's TFDO Synthesis Procedure (http://openflask.blogspot.com/2014/01/tfdo-synthesis-procedure.html). The TFDO solution should be titrated before use. A $0.1 \mathrm{~mL}$ TFDO solution was added into the mixture of $0.5 \mathrm{~mL} \mathrm{H}_{2} \mathrm{O}, 1.5 \mathrm{~mL} \mathrm{AcOH}$ and $0.25 \mathrm{~mL}$ saturated $\mathrm{KI}$ at $-78^{\circ} \mathrm{C}$. This dark red solution was then titrated with $0.05 \mathrm{M} \mathrm{Na}_{2} \mathrm{~S}_{2} \mathrm{O}_{3}$ at room temperature.

NOTE 2: The endo lactol epimer of $\mathbf{1 0}$ was observed to irreversibly decompose via intramolecular epoxide opening (endo-10 to SI-2) during storage either neat or as solution in $\mathrm{CH}_{2} \mathrm{Cl}_{2}$ in a $-20^{\circ} \mathrm{C}$ freezer. The less polar SI-2 could be isolated as a white solid. Due to decomposition, using lactol 10 directly with minimal storage time is strongly recommended.

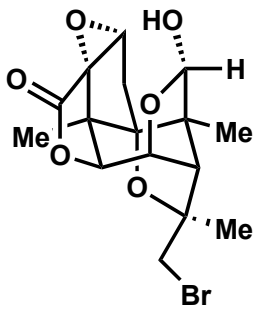

endo-10

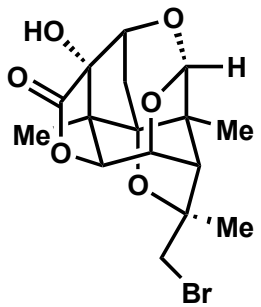

SI-2

Characterization data of lactol 10 (major diastereomer):

Description colorless oil 
$\underline{R_{f}} \quad 0.37$ in $30 \% \mathrm{EtOAc} / \mathrm{CH}_{2} \mathrm{Cl}_{2}$. Stains red purple in anisaldehyde.

Opt. Rot. $\quad \alpha_{\text {obs }}=-42.5^{\circ}, \mathrm{c}=1.00$ in $\mathrm{CH}_{2} \mathrm{Cl}_{2}, \mathrm{~T}=20.0^{\circ} \mathrm{C}$

${ }^{1} \mathrm{H}$ NMR $\quad\left(600 \mathrm{MHz}, \mathrm{CDCl}_{3}\right)$

$\delta 5.33(\mathrm{~s}, 1 \mathrm{H}), 4.88(\mathrm{dd}, J=5.4 \mathrm{~Hz}, J=5.2 \mathrm{~Hz} 1 \mathrm{H}), 4.61(\mathrm{~d}, J=5.4 \mathrm{~Hz}, 1 \mathrm{H}), 4.11(\mathrm{dd}, J=3.8$,

$1.5 \mathrm{~Hz}, 1 \mathrm{H}), 3.44(\mathrm{~d}, J=11.2 \mathrm{~Hz}, 1 \mathrm{H}), 3.35(\mathrm{~d}, J=10.6 \mathrm{~Hz}, 1 \mathrm{H}), 2.91(\mathrm{~d}, J=5.2 \mathrm{~Hz}, 1 \mathrm{H}), 2.47$

$(\mathrm{dd}, J=14.6,3.8 \mathrm{~Hz}, 1 \mathrm{H}), 1.96(\mathrm{~d}, J=14.6 \mathrm{~Hz}, 1 \mathrm{H}), 1.58(\mathrm{~s}, 3 \mathrm{H}), 1.38(\mathrm{~s}, 3 \mathrm{H}), 1.29$ (s, 3H).

${ }^{13} \mathrm{C} \mathrm{NMR} \quad\left(150 \mathrm{MHz}, \mathrm{CDCl}_{3}\right)$

$\delta$ 170.4, 98.7, 96.7, 82.7, 81.0, 76.6, 68.4, 62.4, 59.1, 57.6, 46.6, 38.6, 33.6, 26.5, 19.4, 17.8 .

$\underline{\text { HRMS }}$ Calculated $\mathrm{C}_{16} \mathrm{H}_{20} \mathrm{BrO}_{6}[\mathrm{M}+\mathrm{H}]: 387.0443$ I Found: 387.0439 .

$\underline{X \text {-ray }}$ N/A, oil

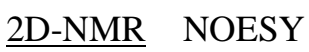

\section{$\underline{3.13 \text { Fragmentation of } \mathbf{1 0} \text { to form } \mathbf{1 1}}$}

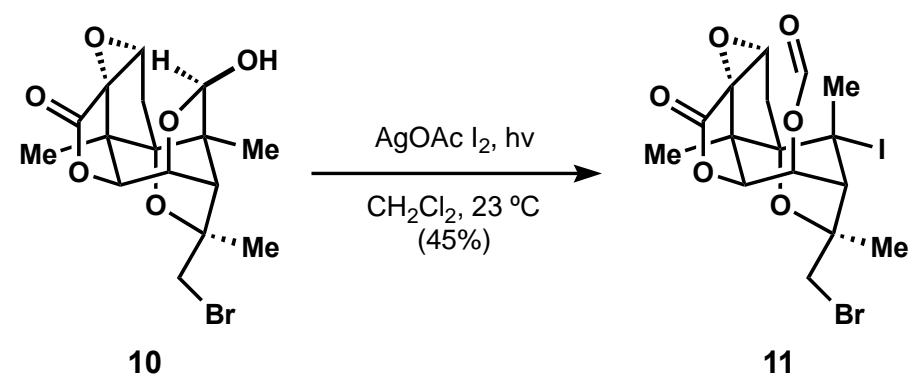

Procedure:

A $25 \mathrm{~mL}$ screw cap test tube was charged with a solution of lactol 10 (20 mg, $0.052 \mathrm{mmol}, 1$ equiv) in $\mathrm{CH}_{2} \mathrm{Cl}_{2}$ ( $3 \mathrm{~mL}$ ), AgOAc (52 mg, $0.31 \mathrm{mmol}, 6$ equiv) and $\mathrm{I}_{2}(79 \mathrm{mg}, 0.31 \mathrm{mmol}, 6$ equiv) in the dark. (The hood lights were kept off during this process and the reaction was wrapped with aluminum foil). After stirring for 10 min in the dark, the hood lamps were turned on, and the reaction was vigorously stirred at room temperature under ambient light for 1 hour. The reaction was monitored by TLC for consumption of starting material. The reaction was quenched by saturated $\mathrm{Na}_{2} \mathrm{~S}_{2} \mathrm{O}_{3}(0.5 \mathrm{~mL})$ then filtered through a short pad of Celite, washed with $\mathrm{CH}_{2} \mathrm{Cl}_{2}(3$ $\mathrm{x} 5 \mathrm{~mL}$ ) and concentrated in vacuo. The crude product was purified by column chromatography over silica gel (15\% EtOAc/Hexane) to afford iodide formate $11(12 \mathrm{mg}, 0.023 \mathrm{mmol}, 45 \%)$ as a colorless oil.

NOTE: Due to the sensitivity of iodide formate $\mathbf{1 1}$ to light, storage of this compound in a $\mathrm{CH}_{2} \mathrm{Cl}_{2}$ solution covered with aluminum foil in the $-20^{\circ} \mathrm{C}$ freezer is recommended.

\section{Characterization data of iodide 11:}

Description colorless oil

$\underline{R}_{f} \quad 0.63$ in $33 \%$ EtOAc/Hexane. Stains brown in anisaldehyde.

Opt. Rot. $\quad \alpha_{\mathrm{obs}}=+24.0^{\circ}, \mathrm{c}=0.40$ in $\mathrm{CHCl}_{3}, \mathrm{~T}=20.0^{\circ} \mathrm{C}$

$\underline{{ }^{1} \mathrm{H} \mathrm{NMR}} \quad\left(600 \mathrm{MHz}, \mathrm{CDCl}_{3}\right)$

$\delta 8.09(\mathrm{~d}, J=1.1 \mathrm{~Hz}, 1 \mathrm{H}), 5.55(\mathrm{~d}, J=8.7 \mathrm{~Hz}, 1 \mathrm{H}), 4.95(\mathrm{~d}, J=8.7 \mathrm{~Hz}, 1 \mathrm{H}), 4.01(\mathrm{dd}, J=3.9$, $1.6 \mathrm{~Hz}, 1 \mathrm{H}), 3.44(\mathrm{~d}, J=10.6 \mathrm{~Hz}, 1 \mathrm{H}), 3.36(\mathrm{~d}, J=10.6 \mathrm{~Hz}, 1 \mathrm{H}), 2.99(\mathrm{~d}, J=1.4 \mathrm{~Hz}, 1 \mathrm{H}), 2.81$ $(\mathrm{dd}, J=15.1,4.0 \mathrm{~Hz}, 1 \mathrm{H}), 2.59$ (s, 3H), $2.22-2.14(\mathrm{~m}, 4 \mathrm{H}), 1.35$ (s, 3H).

${ }^{13} \mathrm{C} \mathrm{NMR} \quad\left(150 \mathrm{MHz}, \mathrm{CDCl}_{3}\right)$ 
$\delta$ 169.7, 159.0, 102.8, 83.8, 76.5, 68.7, 68.1, 62.8, 60.5, 58.9, 44.1, 40.2, 39.7, 32.6, 28.9, 20.0.

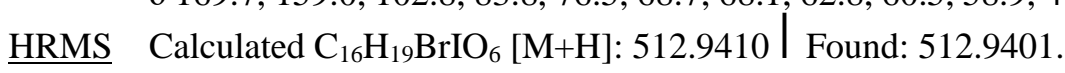

X-ray N/A, oil

2D-NMR NOESY

\section{$\underline{3.14}$ Reductive deiodination and deformylation of $\mathbf{1 1}$ to $\mathbf{1 2}$}

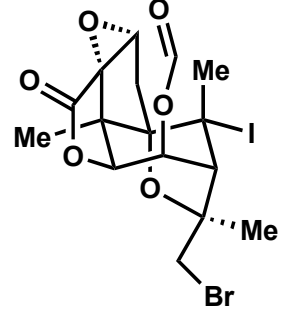

11

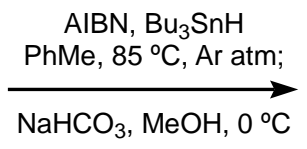

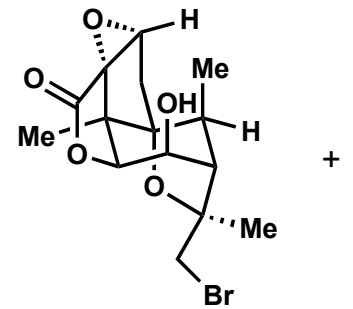

$12(64 \%)$

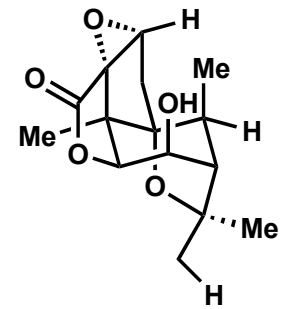

des-Br-12 (12\%)

Procedure:

To a $10 \mathrm{~mL}$ microwave tube were added a solution of iodide formate 11 ( $24 \mathrm{mg}, 0.047 \mathrm{mmol}, 1$ equiv) in toluene ( $5 \mathrm{~mL}$, freshly distilled over sodium and benzophenone), AIBN ( $3.8 \mathrm{mg}, 0.023 \mathrm{mmol}, 0.5$ equiv) and $n \mathrm{Bu}_{3} \mathrm{SnH}$ $(16 \mu \mathrm{L}, 0.061 \mathrm{mmol}, 1.3$ equiv) in the dark. The reaction mixture was then degassed using 5 freeze-pump-thaw cycles. (Each freeze-pump-thaw cycle was conducted as described: the reaction mixture was frozen in liquid $\mathrm{N}_{2}$ for $10 \mathrm{~min}$, then evacuated under high vacuum and backfilled with argon gas three times. The mixture was then warmed up to room temperature to melt the solid.) The reaction mixture was heated at $85{ }^{\circ} \mathrm{C}$ for 30 min and consumption of starting material was monitored by TLC. Upon completion, the solvent was removed under high vacuum to give a pale-yellow residue. The residue was cooled to $0{ }^{\circ} \mathrm{C}$, then methanol $(4 \mathrm{~mL})$ and a saturated $\mathrm{NaHCO}_{3}(0.2 \mathrm{~mL})$ solution were added. After stirring at $0^{\circ} \mathrm{C}$ for $1 \mathrm{~h}$, reaction was concentrated in vacuo. The crude product was purified by silica gel chromatography (50\% EtOAc/Hexane) to afford $\mathbf{1 2}$ (10.8 $\mathrm{mg}, 0.03$ $\mathrm{mmol}, 64 \%)$ as a colorless oil and $\boldsymbol{d e s}-\mathbf{B r}-\mathbf{1 2}(1.5 \mathrm{mg}, 0.006 \mathrm{mmol}, 12 \%)$ as a white solid.

NOTE 1: To minimize decomposition of ambient light-sensitive iodide formate 11, all manipulations of this reaction should be conducted with minimal exposure to light. The hood lights were kept off during this process and the reaction was wrapped with aluminum foil.

NOTE 2: Five freeze-pump-thaw cycles were found to be necessary for efficient reduction of the tertiary iodide 11. Less thorough degassing procedures allow for oxygen incorporation at C5.

\section{Characterization data of 12:}

Description colorless oil

$\underline{R}_{f} 0.56$ in $50 \%$ EtOAc/Hexane. Stains purple in anisaldehyde.

Opt. Rot. $\quad \alpha_{\mathrm{obs}}=-3.2^{\circ}, \mathrm{c}=0.25$ in $\mathrm{CHCl}_{3}, \mathrm{~T}=20.0^{\circ} \mathrm{C}$

$\underline{{ }^{1} \mathrm{H} \mathrm{NMR}}\left(600 \mathrm{MHz}, \mathrm{CDCl}_{3}\right)$

$\delta 4.77(\mathrm{~d}, J=8.5 \mathrm{~Hz}, 1 \mathrm{H}), 4.64(\mathrm{~d}, J=8.4 \mathrm{~Hz}, 1 \mathrm{H}), 3.87(\mathrm{dd}, J=3.8,1.5 \mathrm{~Hz}, 1 \mathrm{H}), 3.36(\mathrm{~d}, J=$ $10.4 \mathrm{~Hz}, 1 \mathrm{H}), 3.20(\mathrm{~d}, J=10.4 \mathrm{~Hz}, 1 \mathrm{H}), 2.46-2.38(\mathrm{~m}, 1 \mathrm{H}), 2.33(\mathrm{~d}, J=3.9 \mathrm{~Hz}, 1 \mathrm{H}), 2.16(\mathrm{~d}$, $J=14.3 \mathrm{~Hz}, 1 \mathrm{H}), 2.06(\mathrm{dd}, J=14.3,3.8 \mathrm{~Hz}, 1 \mathrm{H}), 1.49(\mathrm{~s}, 3 \mathrm{H}), 1.24(\mathrm{~d}, J=8.0 \mathrm{~Hz}, 3 \mathrm{H}), 1.13$ $(\mathrm{s}, 3 \mathrm{H})$.

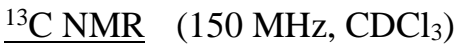


$\delta$ 170.4, 97.2, 83.0, 78.8, 68.2, 66.2, 62.3, 51.4, 42.3, 42.1, 37.4, 35.9, 27.1, 17.8, 11.9.

HRMS Calculated $\mathrm{C}_{15} \mathrm{H}_{20} \mathrm{BrO}_{5}[\mathrm{M}+\mathrm{H}]: 359.0494$ I Found: 359.0497.

2D-NMR NOESY

Characterization data of $\mathbf{d e s}-\mathbf{B r}-\mathbf{1 2}$ :

Description white solid

$\underline{R_{f}} 0.32$ in $50 \% \mathrm{EtOAc} / \mathrm{Hexane}$. Stains purple in anisaldehyde.

Opt. Rot. $\quad \alpha_{\text {obs }}=+22.9^{\circ}, \mathrm{c}=0.14$ in $\mathrm{MeOH}, \mathrm{T}=20.0^{\circ} \mathrm{C}$

${ }^{1} \mathrm{H}$ NMR $\quad\left(600 \mathrm{MHz}, \mathrm{CDCl}_{3}\right)$

$\delta 4.75(\mathrm{~d}, J=8.5 \mathrm{~Hz}, 1 \mathrm{H}), 4.52(\mathrm{~d}, J=8.5 \mathrm{~Hz}, 1 \mathrm{H}), 3.86(\mathrm{dd}, J=3.8,1.4 \mathrm{~Hz}, 1 \mathrm{H}), 2.36(\mathrm{ddd}, J$

$=7.9,4.0,1.4 \mathrm{~Hz}, 1 \mathrm{H}), 2.13(\mathrm{t}, J=7.5 \mathrm{~Hz}, 2 \mathrm{H}), 2.08-2.00(\mathrm{~m}, 1 \mathrm{H}), 1.30(\mathrm{~s}, 3 \mathrm{H}), 1.27(\mathrm{~s}, 3 \mathrm{H})$,

$1.22(\mathrm{~d}, J=8.0 \mathrm{~Hz}, 3 \mathrm{H}), 1.14(\mathrm{~s}, 3 \mathrm{H})$.

${ }^{13} \mathrm{C} \mathrm{NMR} \quad\left(150 \mathrm{MHz}, \mathrm{CDCl}_{3}\right)$

$\delta 170.8,96.6,81.7,79.1,68.3,67.3,62.6,52.4,42.4,42.1,35.9,30.9,25.9,17.8,12.0$.

HRMS Calculated $\mathrm{C}_{15} \mathrm{H}_{21} \mathrm{O}_{5}[\mathrm{M}+\mathrm{H}]: 281.1389$ | Found: 281.1383 .

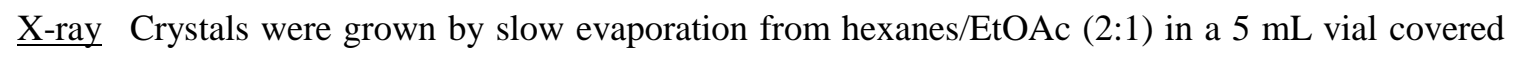
with Teflon tape at room temperature.

2D-NMR NOESY

\section{$\underline{3.15 \text { Oxidation of } \mathbf{1 2} \text { to bromopicrotoxinin (SI-3) }}$}

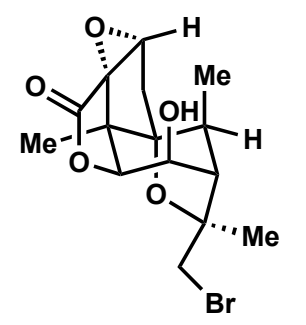

12

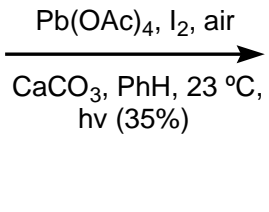

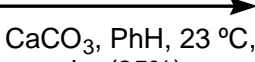
v $(35 \%)$

Procedure:

To a solution of $\mathrm{Pb}(\mathrm{OAc})_{4}(53 \mathrm{mg}, 0.12 \mathrm{mmol}, 5$ equiv, freshly recrystallized from $\mathrm{AcOH}$, then washed three times with hexane) in benzene $(2 \mathrm{~mL})$ was added $\mathrm{I}_{2}(30 \mathrm{mg}, 0.12 \mathrm{mmol}, 5$ equiv) in the dark (covered with aluminum foil and hood light turned off) at room temperature and stirred for $30 \mathrm{~min}$. To a suspension of $\mathbf{1 2}$ (8.6 $\mathrm{mg}, 0.024 \mathrm{mmol}, 1$ equiv), $\mathrm{CaCO}_{3}(24 \mathrm{mg}, 0.24 \mathrm{mmol}, 10$ equiv) in benzene $(1 \mathrm{~mL})$ was added the $\mathrm{Pb}(\mathrm{OAc})_{4} / \mathrm{I}_{2} / \mathrm{PhH}$ solution at room temperature under ambient atmosphere. The hood lamps were turned on, and the reaction was vigorously stirred at room temperature under ambient light for 2.5 hours. Consumption of starting material was monitored by TLC. The reaction was quenched with saturated $\mathrm{Na}_{2} \mathrm{~S}_{2} \mathrm{O}_{3}(0.5 \mathrm{~mL})$ then filtered through a short pad of celite, washed with EtOAc $(3 \times 5 \mathrm{~mL})$, and concentrated in vacuo. The crude product was purified by prep thin layer chromatography (50\% EtOAc/Hexane) to afford bromopicrotoxinin SI3 (3.1 $\mathrm{mg}, 0.008 \mathrm{mmol}, 35 \%)$ as a white solid.

\section{Characterization data of SI-3:}

Description white solid

$\underline{R_{f}} 0.53$ in $50 \% \mathrm{EtOAc/Hexane.} \mathrm{Stains} \mathrm{brown} \mathrm{in} \mathrm{anisaldehyde.}$ 
Opt. Rot. $\alpha_{\mathrm{obs}}=-123.6^{\circ}, \mathrm{c}=0.28$ in $\mathrm{CH}_{2} \mathrm{Cl}_{2}, \mathrm{~T}=20.0^{\circ} \mathrm{C}\left[c f . J A C S\right.$ 1989, $111,3728:[\alpha]^{27} \mathrm{D}=-126^{\circ}(\mathrm{c}=0.21$, $\left.\left.\mathrm{CHCl}_{3}\right)\right]$

$\underline{{ }^{1} \mathrm{H} \mathrm{NMR}} \quad\left(600 \mathrm{MHz}, \mathrm{CDCl}_{3}\right)$

$\delta 5.23(\mathrm{td}, J=5.2,1.0 \mathrm{~Hz}, 1 \mathrm{H}), 4.71(\mathrm{~d}, J=5.1 \mathrm{~Hz}, 1 \mathrm{H}), 4.06(\mathrm{dd}, J=3.6,1.2 \mathrm{~Hz}, 1 \mathrm{H}), 3.51-$ $3.40(\mathrm{~m}, 3 \mathrm{H}), 3.06(\mathrm{dd}, J=5.3,0.8 \mathrm{~Hz}, 1 \mathrm{H}), 2.45(\mathrm{dd}, J=14.0,3.6 \mathrm{~Hz}, 1 \mathrm{H}), 2.27-2.19(\mathrm{~m}$, $1 \mathrm{H}), 1.56(\mathrm{~s}, 3 \mathrm{H}), 1.33(\mathrm{~s}, 3 \mathrm{H})$.

${ }^{13} \mathrm{C} \mathrm{NMR} \quad\left(150 \mathrm{MHz}, \mathrm{CDCl}_{3}\right)$

$\delta 170.3,168.1,94.7,85.0,77.63,77.59,67.7,63.3,55.7,54.2,47.2,38.4,35.4,27.9,16.9$.

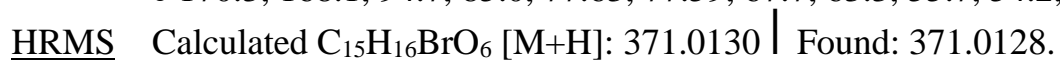

X-ray Crystals were grown by slow evaporation of a solution of $\mathbf{S I - 3}$ in hexanes, EtOAc, $\mathrm{CH}_{2} \mathrm{Cl}_{2}$, and $\mathrm{MeOH}$ at room temperature from a cylindrical glass recrystallization tube placed vertically within a $20 \mathrm{~mL}$ scintillation tube and capped with aluminum foil.

$\underline{3.16}$ Reductive debromination of bromopicrotoxinin (SI-3) to form picrotoxinin (1)

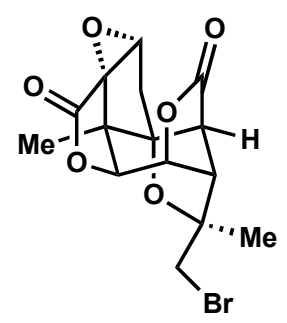

SI-3

Procedure:

$(96 \%)$

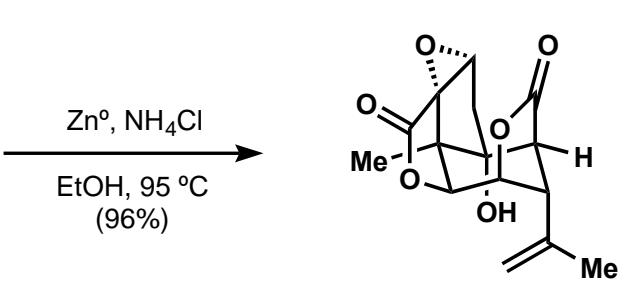

$(-)$-picrotoxinin (1)

Zinc powder (10 mg, $0.15 \mathrm{mmol}, 10$ equiv), $\mathrm{NH}_{4} \mathrm{Cl}$ (16 mg, $0.3 \mathrm{mmol}, 20$ equiv) were added into a solution of bromopicrotoxinin (SI-3) $\left(5.3 \mathrm{mg}, 0.015 \mathrm{mmol}, 1\right.$ equiv) in $\mathrm{EtOH} / \mathrm{H}_{2} \mathrm{O}$ (v:v, 10:1, $2.2 \mathrm{~mL}$ ). Then the reaction was warmed up to $95^{\circ} \mathrm{C}$ and stirred at this temperature for 2 hours. The reaction mixture was diluted by EtOAc then filtered through a short pad of Celite and washed with EtOAc $(3 \times 2 \mathrm{~mL})$. The reaction mixture was concentrated and purified by prep thin layer chromatography $\left(10 \% \mathrm{EtOAc} / \mathrm{CH}_{2} \mathrm{Cl}_{2}\right)$ to give picrotoxinin $(\mathbf{1})(4.2$ $\mathrm{mg}, 0.014 \mathrm{mmol}, 96 \%$ ) as a white solid.

Characterization data of picrotoxinin (1):

Description white solid

$\underline{R}_{f} 0.38$ in $10 \% \mathrm{EtOAc} / \mathrm{CH}_{2} \mathrm{Cl}_{2}$. Stains dark blue in anisaldehyde.

Opt. Rot. $\alpha_{\mathrm{obs}}=-9.5^{\mathrm{o}}, \mathrm{c}=0.20$ in $\mathrm{CHCl}_{3}, \mathrm{~T}=20.0^{\circ} \mathrm{C}\left[c f . J A C S\right.$ 1984, 106, 4547: $[\alpha]^{27} \mathrm{D}=-6.7^{\circ}(\mathrm{c}=1.03$, $\left.\left.\mathrm{CHCl}_{3}\right)\right]$

${ }^{1} \mathrm{H} \mathrm{NMR} \quad\left(600 \mathrm{MHz}, \mathrm{CDCl}_{3}\right) \delta 5.17-5.01(\mathrm{~m}, 2 \mathrm{H}), 4.89(\mathrm{~d}, J=3.6 \mathrm{~Hz}, 1 \mathrm{H}), 4.85(\mathrm{~d}, J=1.9 \mathrm{~Hz}, 1 \mathrm{H})$, $3.74(\mathrm{~d}, J=3.0 \mathrm{~Hz}, 1 \mathrm{H}), 3.44(\mathrm{~s}, 1 \mathrm{H}), 2.97(\mathrm{dd}, J=15.1,3.6 \mathrm{~Hz}, 2 \mathrm{H}), 1.99(\mathrm{~d}, J=15.1 \mathrm{~Hz}$, $1 \mathrm{H}), 1.96-1.89(\mathrm{~m}, 3 \mathrm{H}), 1.25$ (s, 3H).

${ }^{13} \mathrm{C} \mathrm{NMR} \quad\left(150 \mathrm{MHz}, \mathrm{CDCl}_{3}\right) \delta 173.8,168.7,139.8,113.6,86.3,79.6,77.2,72.4,61.6,50.8,48.7,46.7$, 44.7, 23.3, 16.6.

HRMS Calculated: $\mathrm{C}_{15} \mathrm{H}_{17} \mathrm{O}_{6}[\mathrm{M}+\mathrm{H}]: 293.1025$ I Found: 293.1029. 
X-ray Crystals were grown by slow evaporation of a solution of $\mathbf{1}$ in $\mathrm{CDCl}_{3}$ at room temperature from a cylindrical glass recrystallization tube placed vertically within a $20 \mathrm{~mL}$ scintillation tube and capped with aluminum foil.

$\underline{3.17 \text { Mukaiyama hydration of picrotoxinin (1) to form picrotin (19) }}$

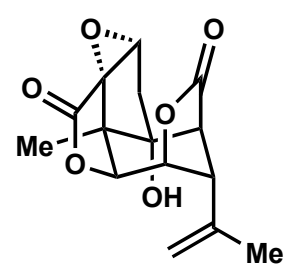

1

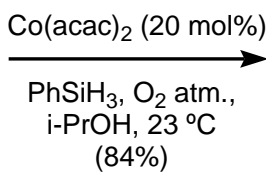

$(84 \%)$

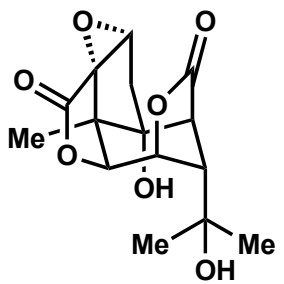

19

Procedure:

To a solution of 1 (18 mg, $0.062 \mathrm{mmol}, 1$ equiv) in $\mathrm{PrOH}(0.4 \mathrm{~mL})$ was added $\mathrm{Co}(\mathrm{acac})_{2}(1.7 \mathrm{mg}, 0.0068 \mathrm{mmol}$, 0.11 equiv) and $\mathrm{PhSiH}_{3}\left(7.4 \mathrm{mg}, 0.068 \mathrm{mmol}, 1.1\right.$ equiv). The reaction was fitted with a balloon of $\mathrm{O}_{2}$ and purged with sonication for $5 \mathrm{~min}$. The reaction was stirred at room temperature for 2 hours at which time TLC analysis showed consumption of starting material. The reaction mixture was concentrated and purified by silica column chromatography to give picrotin (19) $(16 \mathrm{mg}, 84 \%)$ as a white solid.

Characterization data of picrotin (19):

Description white solid

$\underline{R}_{f} \quad 0.16$ in $20 \%$ EtOAc/Hexane. Stains dark blue in anisaldehyde.

Opt. Rot. $\quad \alpha_{\mathrm{obs}}=-43.3^{\circ}, \mathrm{c}=0.24$ in EtOH, $\mathrm{T}=20.0^{\circ} \mathrm{C}\left(c f . J A C S\right.$ 1989, $111,3728:[\alpha]^{25} \mathrm{D}=-69.9^{\circ}(\mathrm{c}=1.07$, $\mathrm{EtOH}))$

1H NMR $(600 \mathrm{MHz}$, Acetone- $d) \delta 5.91(\mathrm{~d}, J=3.5 \mathrm{~Hz}, 1 \mathrm{H}), 5.58(\mathrm{~d}, J=1.3 \mathrm{~Hz} 1 \mathrm{H}), 5.18$ (ddd, $J=5.1$, $3.4,0.7 \mathrm{~Hz}, 1 \mathrm{H}), 4.98(\mathrm{~d}, J=3.4 \mathrm{~Hz}, 1 \mathrm{H}), 3.69(\mathrm{~d}, J=3.3 \mathrm{~Hz}, 1 \mathrm{H}), 3.06$ (ddd, $J=5.2,3.9,1.1$ $\mathrm{Hz}, 1 \mathrm{H}), 2.99-2.93(\mathrm{~m}, 3 \mathrm{H}), 2.88(\mathrm{ddd}, J=14.9,3.6,2.0 \mathrm{~Hz}, 1 \mathrm{H}), 2.13(\mathrm{~d}, J=14.3 \mathrm{~Hz}, 3 \mathrm{H})$, $1.61(\mathrm{~s}, 3 \mathrm{H}), 1.57(\mathrm{~s}, 3 \mathrm{H}), 1.31(\mathrm{~s}, 3 \mathrm{H})$.

${ }^{13} \mathrm{C}$ NMR $\quad(150 \mathrm{MHz}$, Acetone- $d) \delta 175.2,170.1,85.9,81.3,78.5,74.1,69.7,62.3,53.2,51.3,48.7,44.0$, 30.0, 28.8, 16.4. (cf. Phytochem. Anal. 2001, 12, 69. references the ${ }^{1} \mathrm{H}$ NMR spectrum to 2.15 ppm, ${ }^{13} \mathrm{C}$ NMR spectrum $\left.206.15 \mathrm{ppm}\right)$

HRMS Calculated: $\mathrm{C}_{15} \mathrm{H}_{19} \mathrm{O}_{7}[\mathrm{M}+\mathrm{H}]: 311.1131$ Found: 311.1134 .

X-ray The crystal structure of PTN has previously been reported: Acta Crystallographica, Section B: Structural Crystallography and Crystal Chemistry (1976), B32(11), 2987-93. 
3.18 Hydrolytic stability study of picrotoxinin (1) vs (20)

In separate $5 \mathrm{~mm}$ NMR tubes, picrotoxinin $(\mathbf{1}, 1 \mathrm{mg})$ or 5-methyl picrotoxinin $(\mathbf{2 0}, 1 \mathrm{mg})$ were dissolved in 1 $\mathrm{mL}$ of $100 \mathrm{mM}$ phosphate buffer $\left(\mathrm{pH}=8\right.$, prepared with $\left.\mathrm{D}_{2} \mathrm{O}\right)$. Spectra were acquired at $0,6,12,24,36,48$, $60,72,84,96$, and $120 \mathrm{~h}$. and monitored for the amount of hydrolysis product.

\begin{tabular}{|l|l|l|l|l|}
\hline Time $(\mathrm{h})$ & {$[\mathrm{PXN}](\mathrm{mM})$} & $\ln [\mathrm{PXN}]$ & {$[5 \mathrm{MePXN}](\mathrm{mM})$} & $\ln [5 \mathrm{MePXN}]$ \\
\hline 0 & 3.42 & 1.229640551 & 3.27 & 1.184789985 \\
\hline 6 & 3.25714286 & 1.180850387 & 3 & 1.098612289 \\
\hline 12 & 2.97391304 & 1.089878609 & 2.771186441 & 1.019275546 \\
\hline 24 & 2.1242236 & 0.753406372 & 2.440298507 & 0.892120371 \\
\hline 36 & 1.87912088 & 0.63080405 & 2.194630872 & 0.786013865 \\
\hline 48 & 1.41322314 & 0.345873011 & 2.031055901 & 0.708555806 \\
\hline 60 & 1.28089888 & 0.247562079 & 1.912280702 & 0.648296614 \\
\hline 72 & 1.16723549 & 0.154638128 & 1.796703297 & 0.585953484 \\
\hline 84 & 0.9144385 & -0.08944506 & 1.68556701 & 0.522102012 \\
\hline 96 & 0.7755102 & -0.254234138 & 1.64321608 & 0.496655346 \\
\hline 120 & 0.52941176 & -0.635988767 & 1.535211268 & 0.428668005 \\
\hline
\end{tabular}

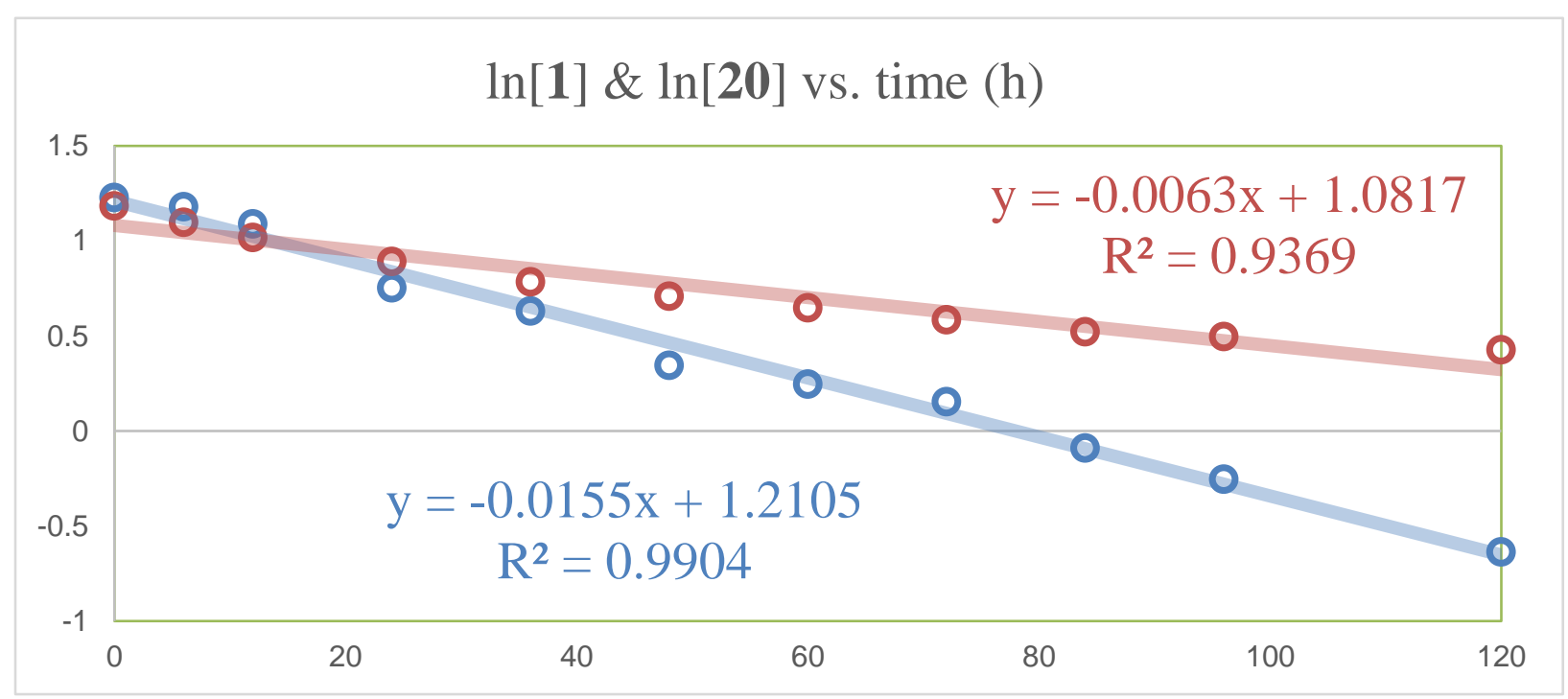




\section{$\underline{3.19}$ Measurement of $\mathrm{IC}_{50}$ value for 5-methyl-picrotoxinin (20)}

A Non-selective Rat GABA A Ion Channel [3H] TBOB Binding (Antagonist Radioligand) Assay (Catalog \#3817) was conducted by Eurofins Pharma Discovery Service of Eurofins Cerep, France.

(https://www.eurofinsdiscoveryservices.com/catalogmanagement/viewitem/Non-Selective-Rat-GABAA-IonChannel-3H-TBOB-Binding-Antagonist-Radioligand-Assay-Cerep/3817).

The assay is based on these publications:

Lewin, A. H. et al. Mol. Pharmacol. 1989, 35, 189.

Schwartz, R. D.; Mindlin, M. C. J. Pharmacol. Exp. Ther. 1987, 244, 963.

Compound binding was calculated as a $\%$ inhibition of the binding of the radioactive ligand $[3 \mathrm{H}] \mathrm{TBOB}(t-$ $\left[{ }^{3} \mathrm{H}\right]$ Butylbicycloorthobenzoate) for RAT GABAA Ion Channels.

A $20.0 \mathrm{mM}$ stock solution was prepared in DMSO from pure solid 5-methyl-picrotoxinin (20) to evaluate radioligand displacement of $[3 \mathrm{H}] \mathrm{TBOB}$ from rat cerebral cortex $\mathrm{GABA}_{\mathrm{A}}$ receptors at final concentrations of $200 \mu \mathrm{M}, 63 \mu \mathrm{M}, 20 \mu \mathrm{M}, 6.3 \mu \mathrm{M}, 2.0 \mu \mathrm{M}$, and $0.6 \mu \mathrm{M}$. An $\mathrm{IC}_{50}$ value of $9.2 \mu \mathrm{M}$ and a $\mathrm{K}_{\mathrm{i}}$ value of $8.2 \mu \mathrm{M}$ were determined for compound 20. Picrotoxinin (1) was used as a standard reference in this assay and exhibited an $\mathrm{IC}_{50}$ value of $0.2 \mu \mathrm{M}$ and a $\mathrm{K}_{\mathrm{i}}$ value of $0.2 \mu \mathrm{M}$.

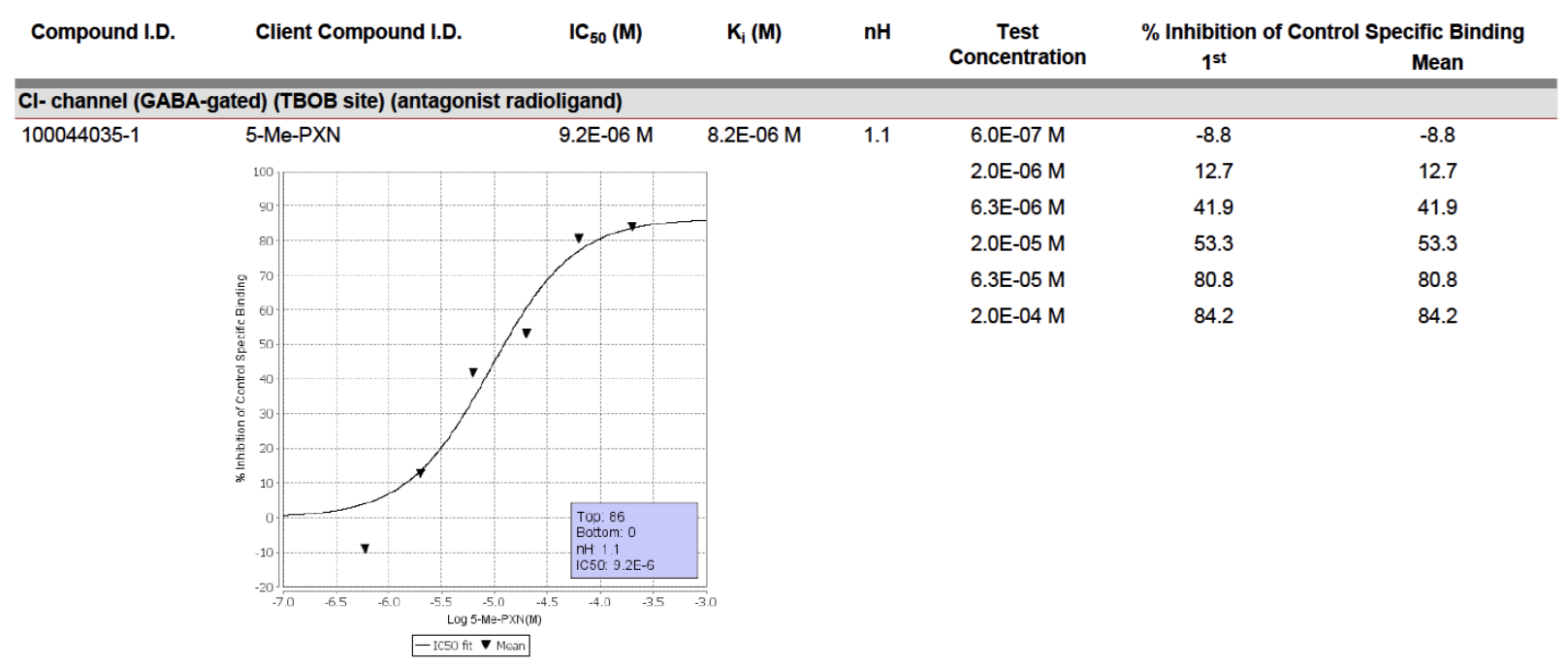


4. NMR spectra

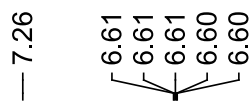
$œ \infty$

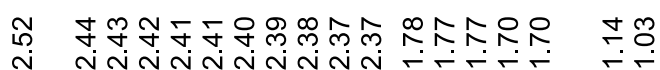
il
nnninninin

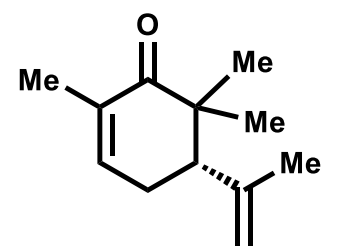

${ }^{1} \mathrm{H} \mathrm{NMR,} \mathrm{CDCl}_{3}, 600 \mathrm{MHz}$

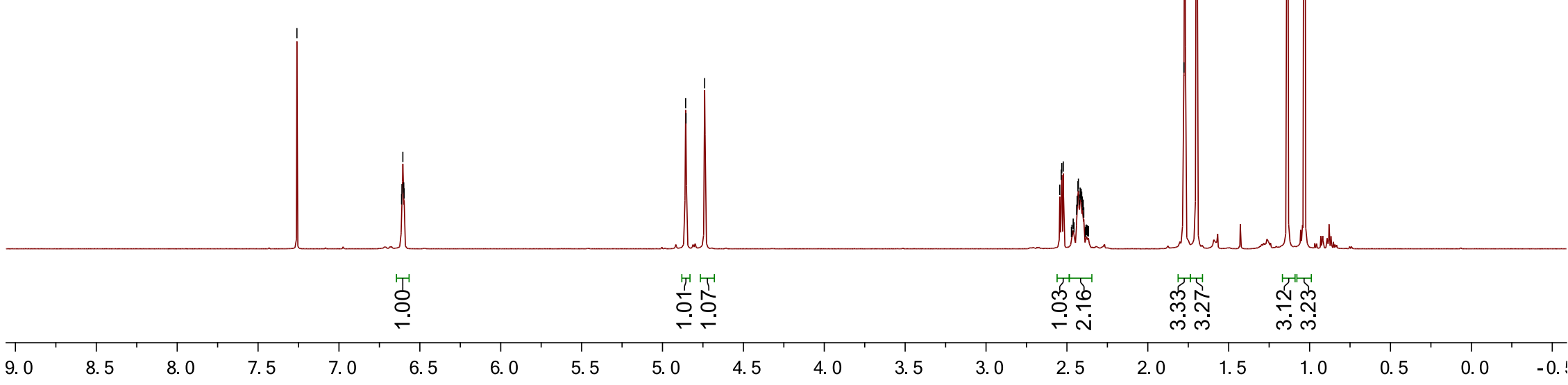




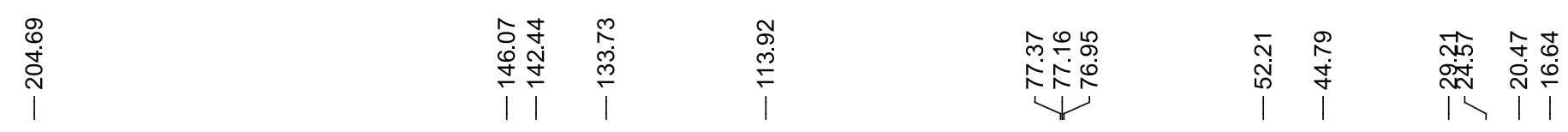

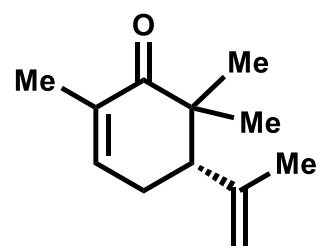

${ }^{13} \mathrm{C} \mathrm{NMR}, \mathrm{CDCl}_{3}, 150 \mathrm{MHz}$

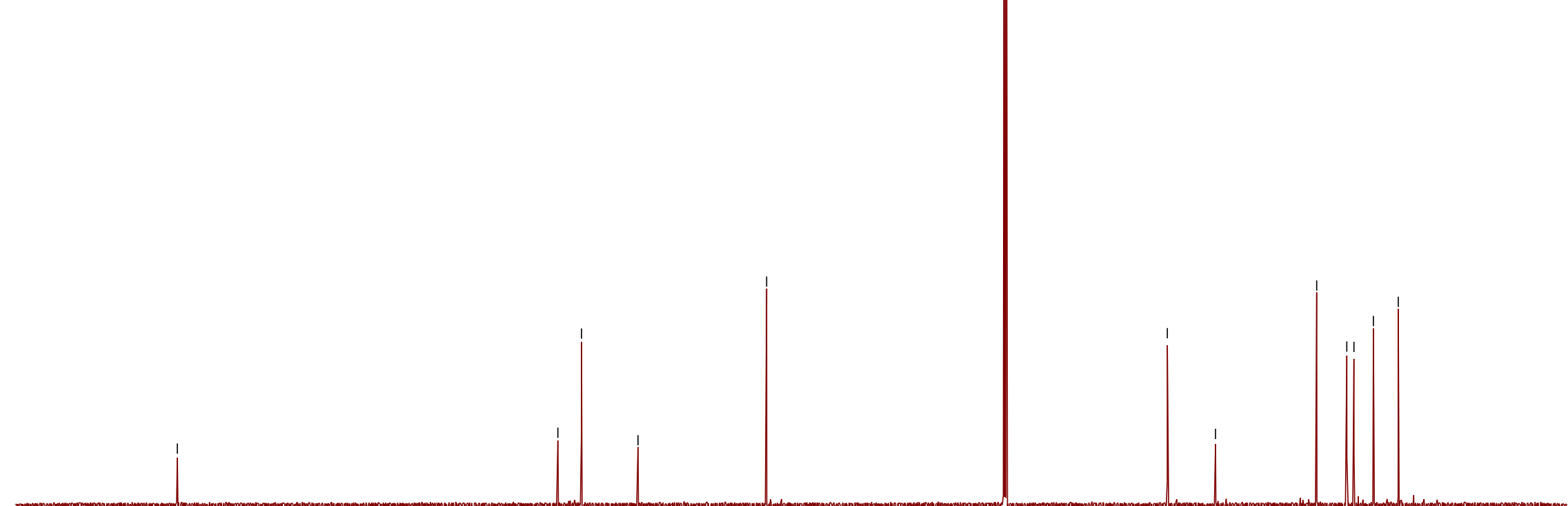



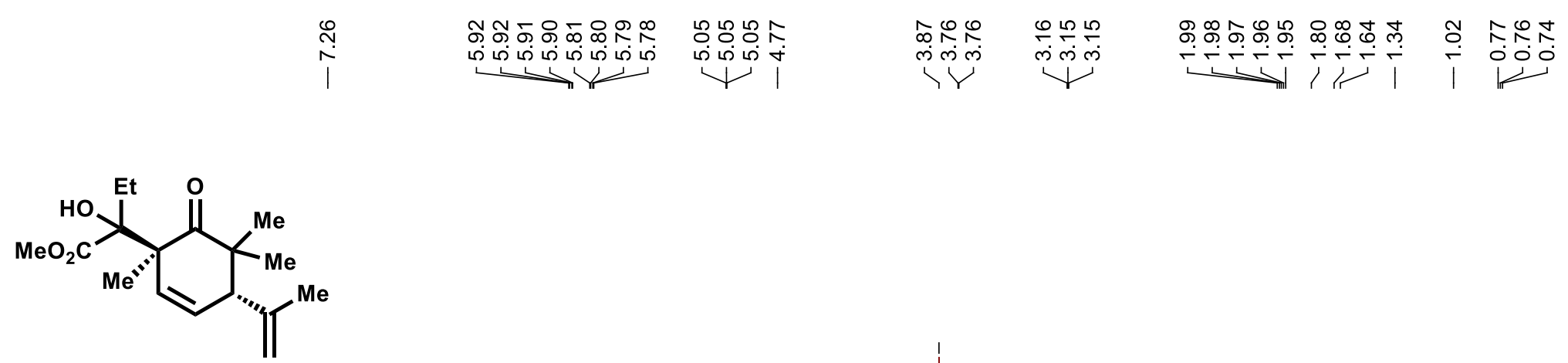

major diastereomer

${ }^{1} \mathrm{H} \mathrm{NMR}, \mathrm{CDCl}_{3}, 600 \mathrm{MHz}$

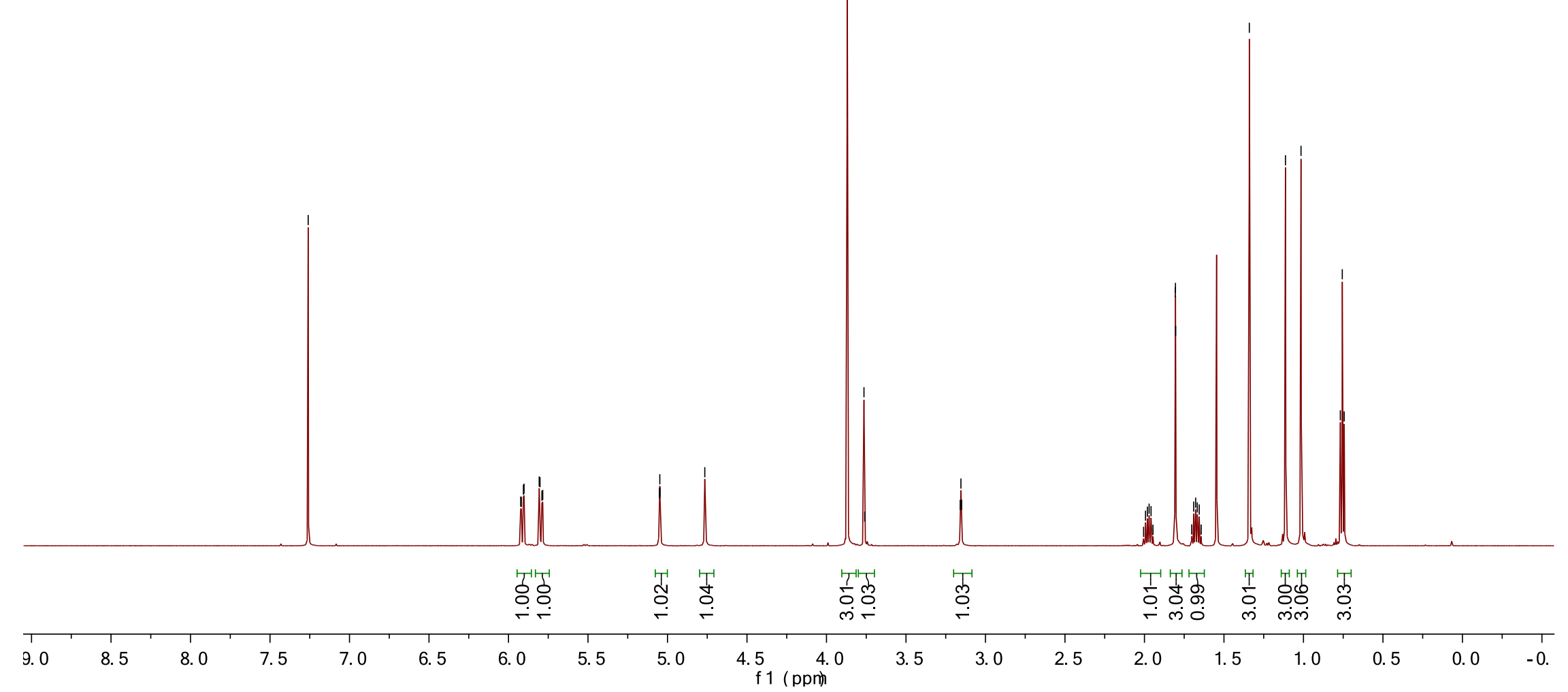




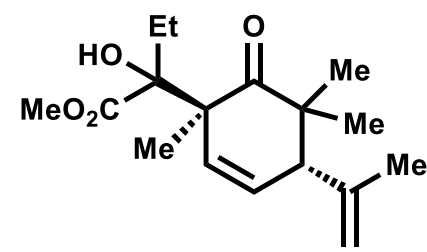

major diastereomer

${ }^{13} \mathrm{C} \mathrm{NMR}, \mathrm{CDCl}_{3}, 150 \mathrm{MHz}$

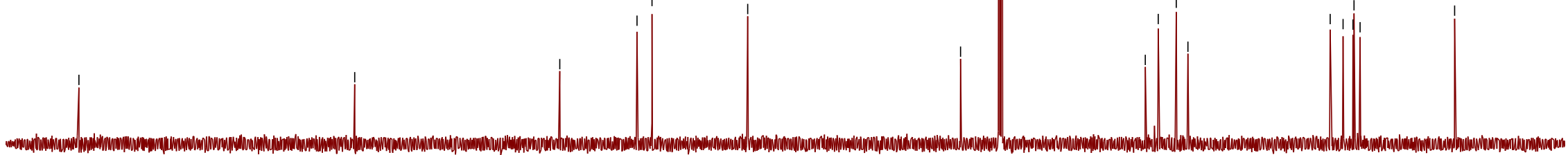




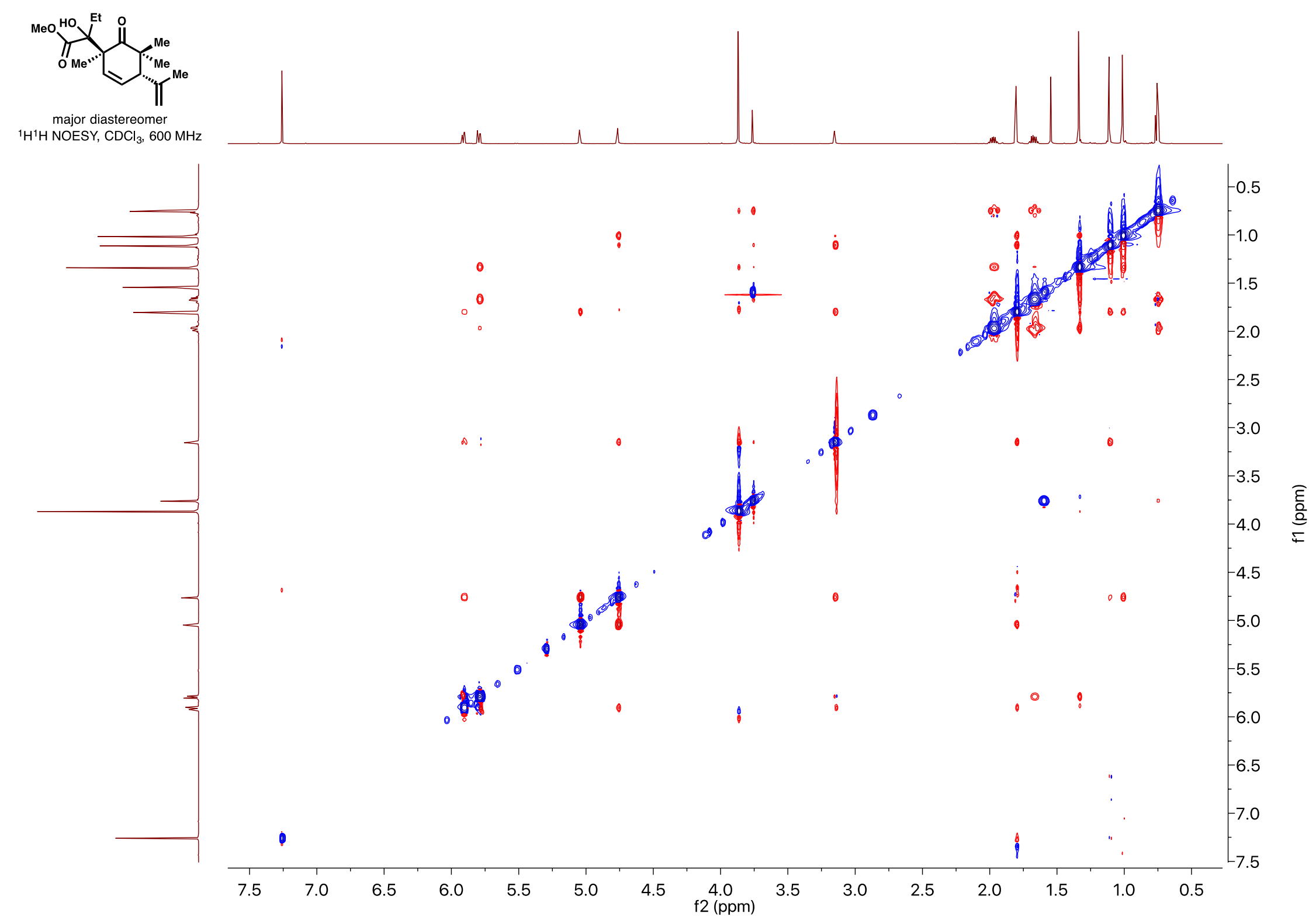




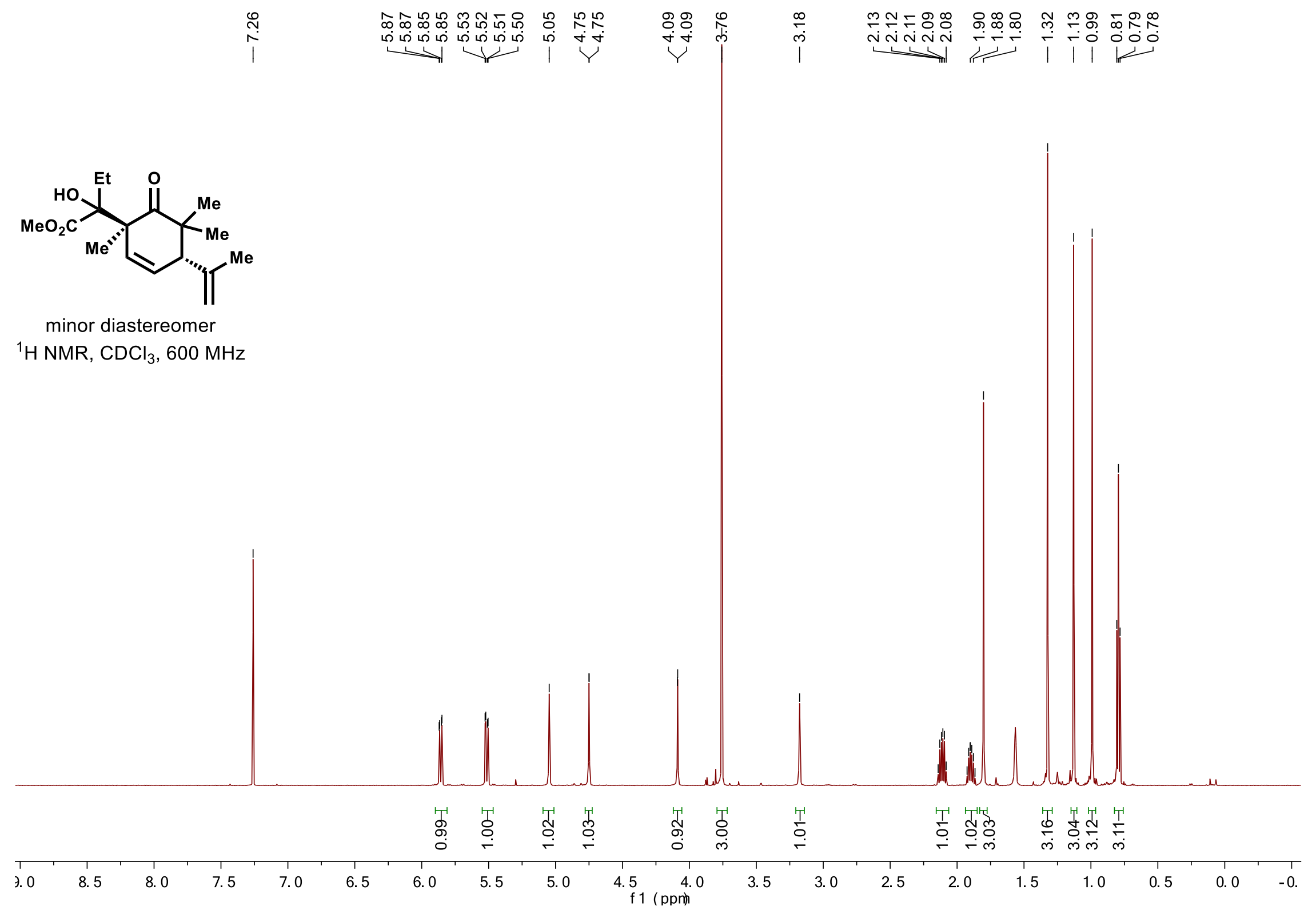




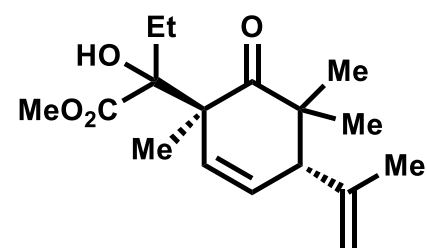

minor diastereomer

${ }^{13} \mathrm{C} \mathrm{NMR}, \mathrm{CDCl}_{3}, 150 \mathrm{MHz}$

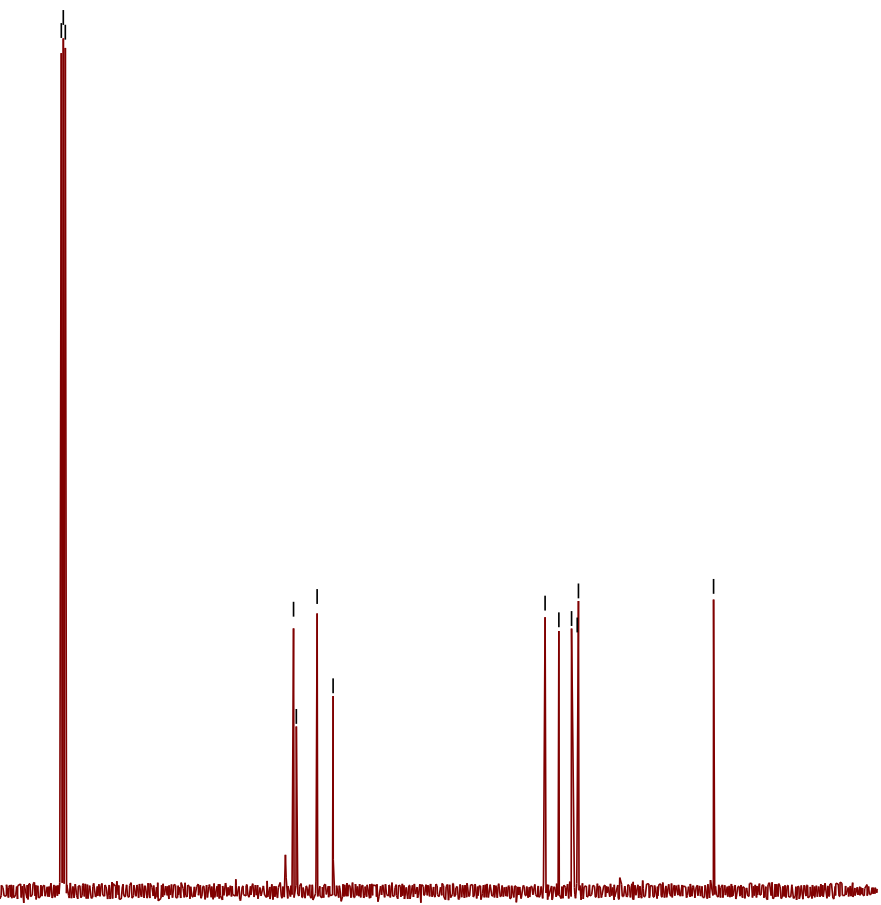




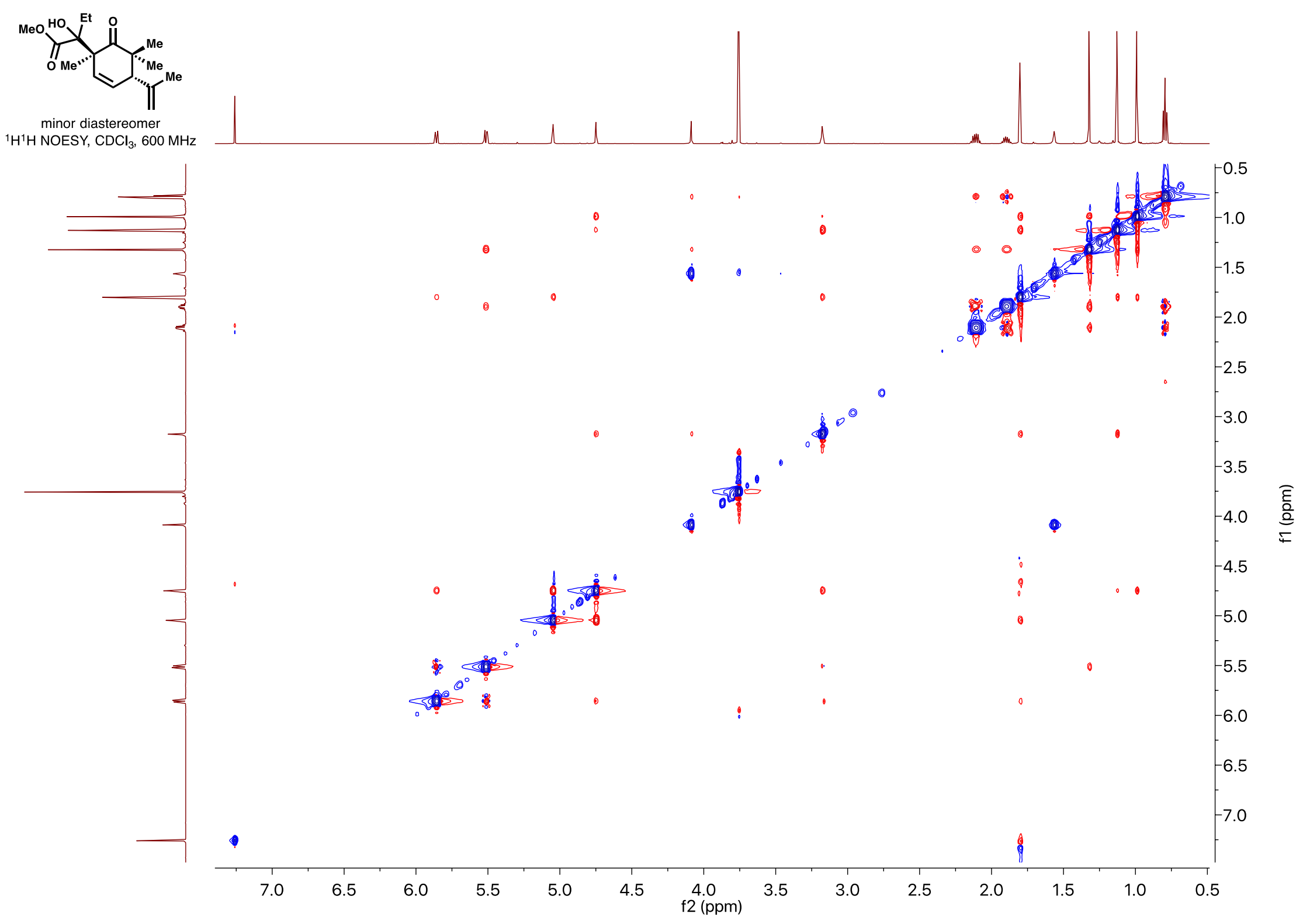




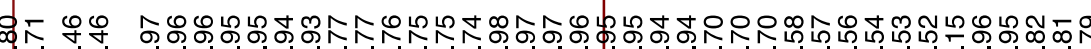

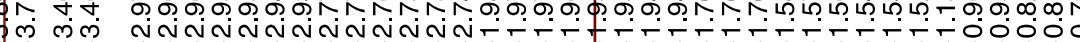

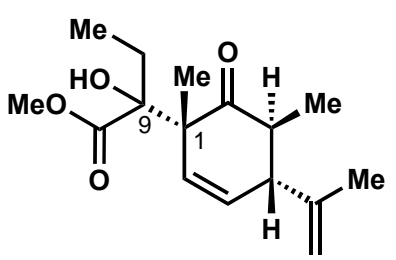

minor diastereomer at C-9

(1.00:0.04 d.r. at $\mathrm{C} 1)$

${ }^{1} \mathrm{H} \mathrm{NMR}, \mathrm{CDCl}_{3}, 600 \mathrm{MHz}$

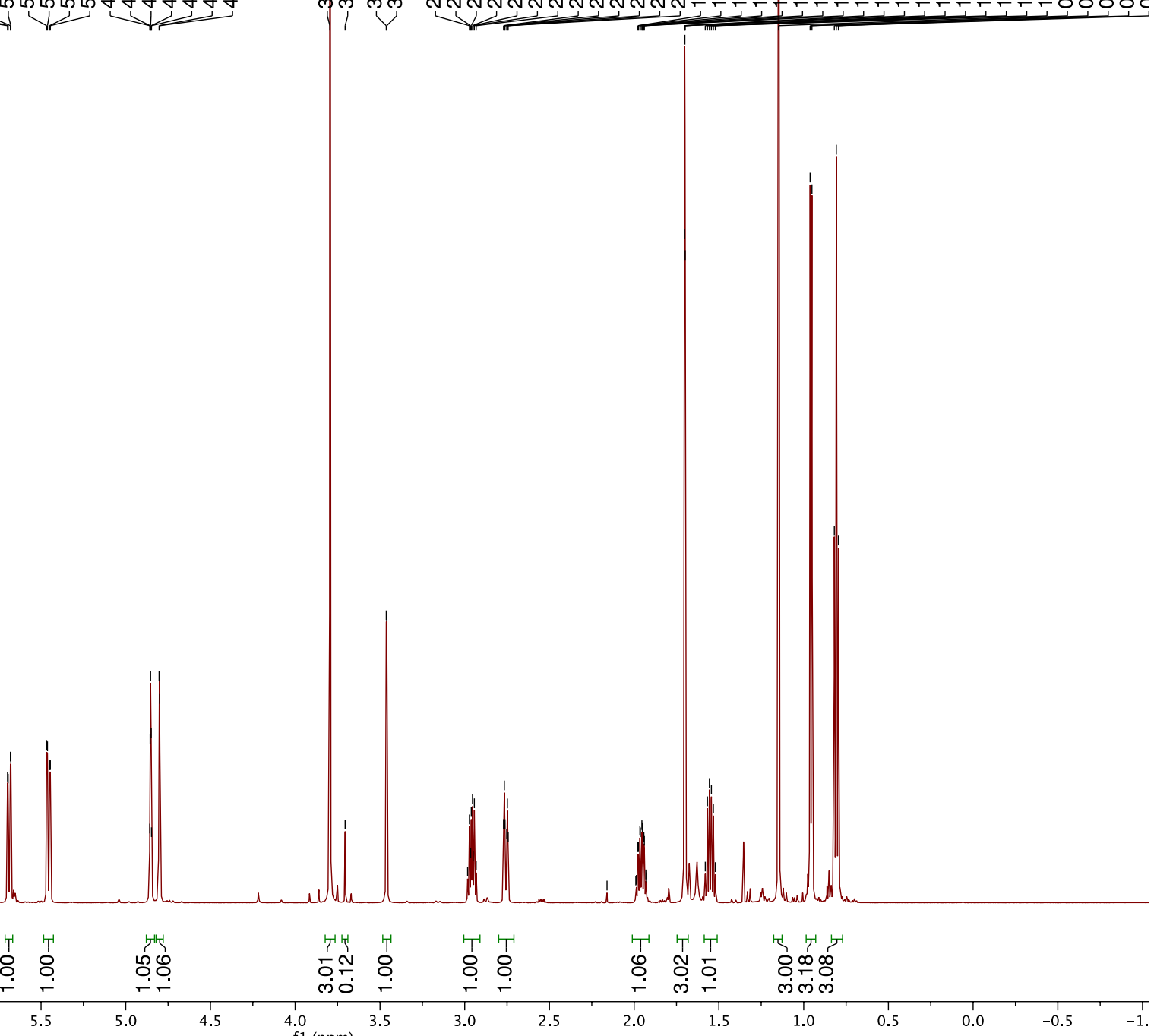




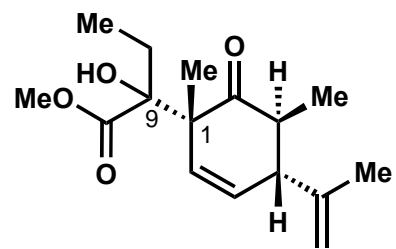

minor diastereomer at C-9

$$
\text { (1.00:0.04 d.r. at C1) }
$$

${ }^{13} \mathrm{C}$ NMR, $\mathrm{CDCl}_{3}, 600 \mathrm{MHz}$

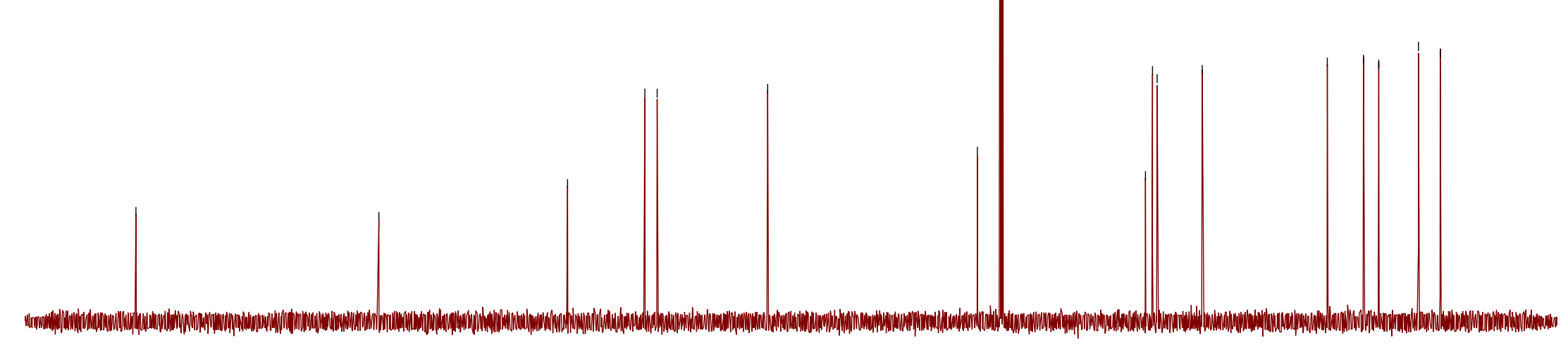

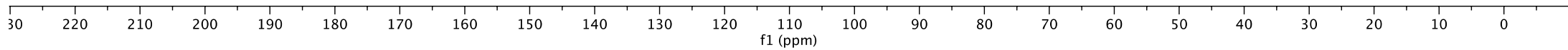




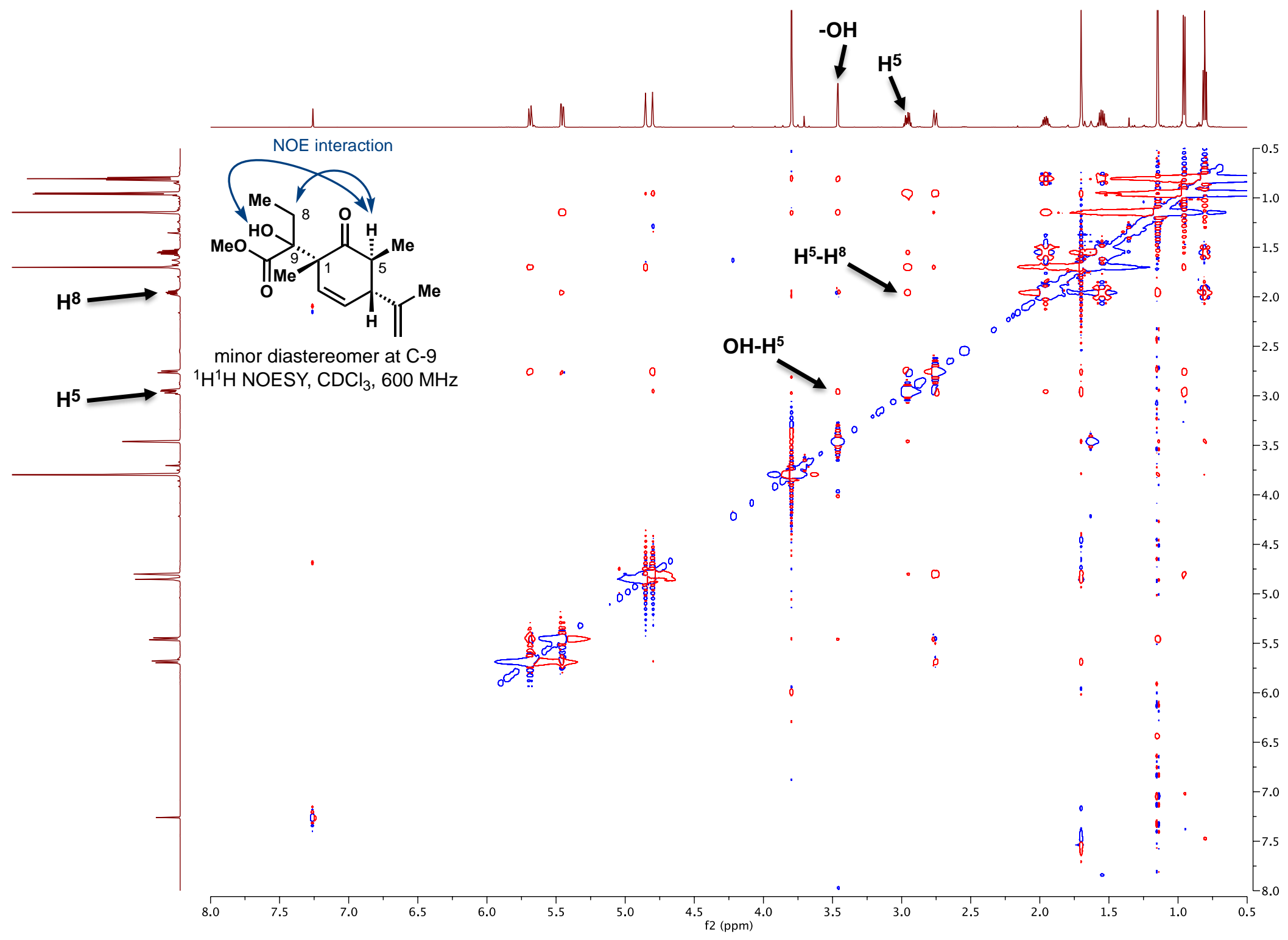




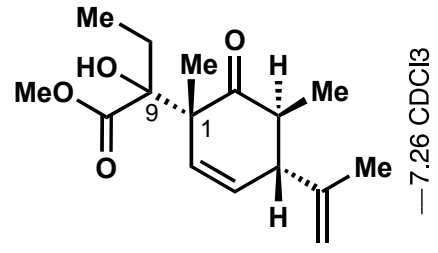

major diastereomer at $\mathrm{C}-9$ (1.00:0.12 d.r. at C1)

${ }^{1} \mathrm{H} \mathrm{NMR}, \mathrm{CDCl}_{3}, 600 \mathrm{MHz}$

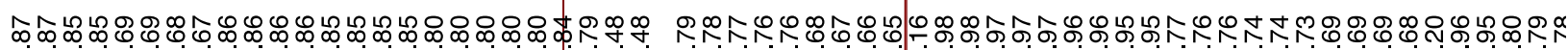

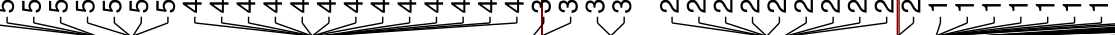

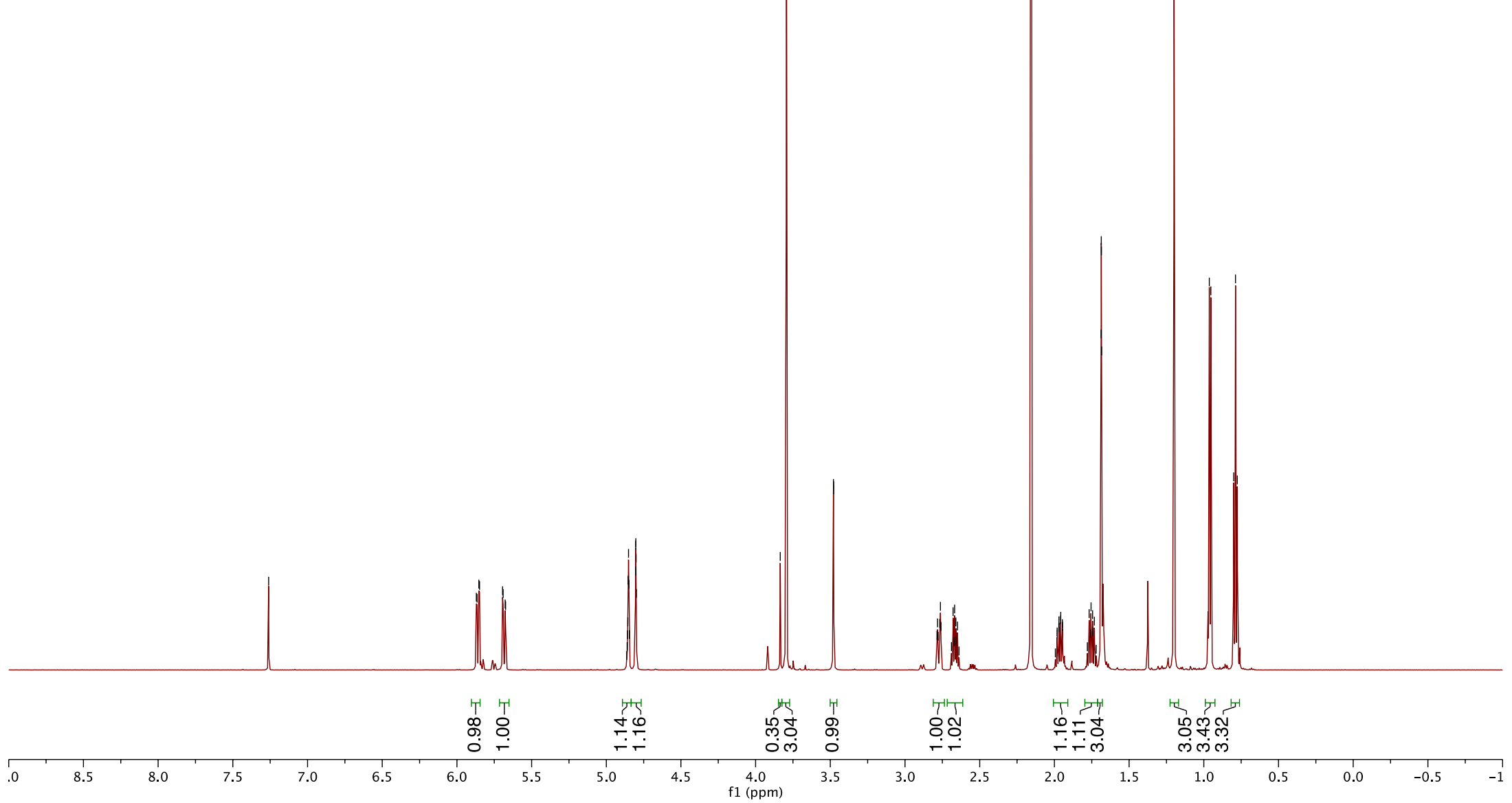




$$
\begin{array}{ll}
\stackrel{9}{\circ} & \infty \\
\stackrel{n}{N} & \stackrel{0}{N} \\
1 & 1
\end{array}
$$

กั

$\frac{9}{N}$
$\stackrel{9}{T}$

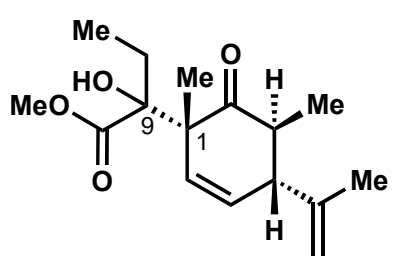

major diastereomer at C-9

(1.00:0.12 d.r. at $\mathrm{C} 1$ )

${ }^{13} \mathrm{C} \mathrm{NMR} \mathrm{CDCl}_{3}, 600 \mathrm{MHz}$

acetone @ 207 \& 31 ppm

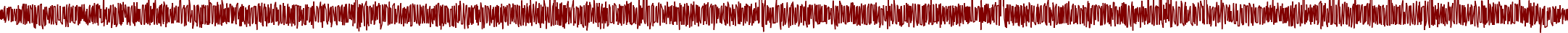

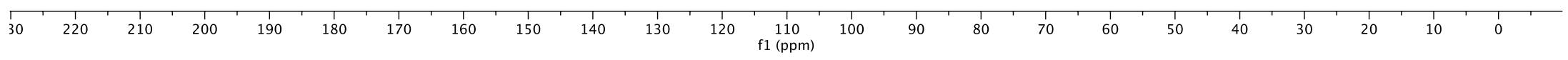




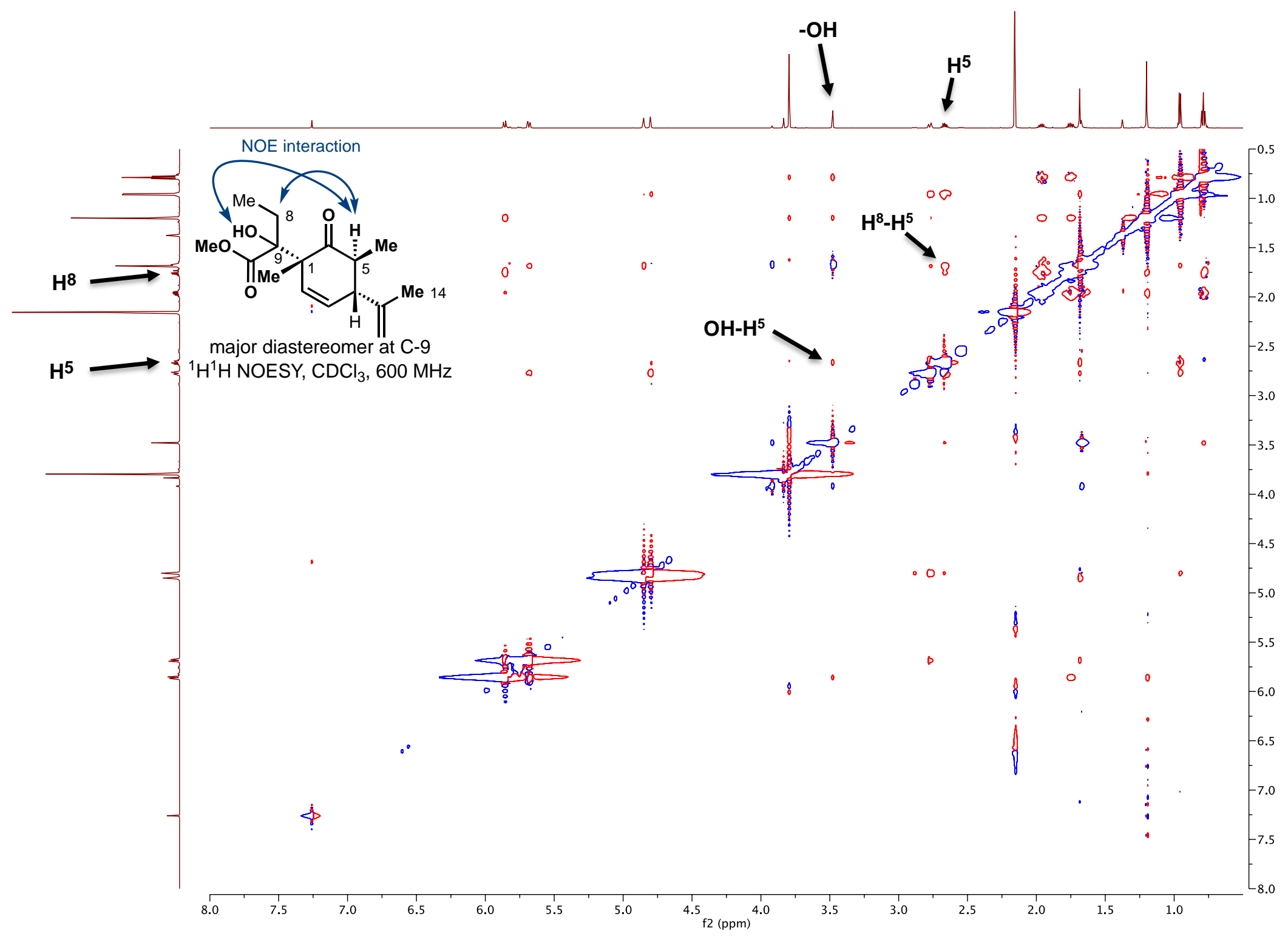



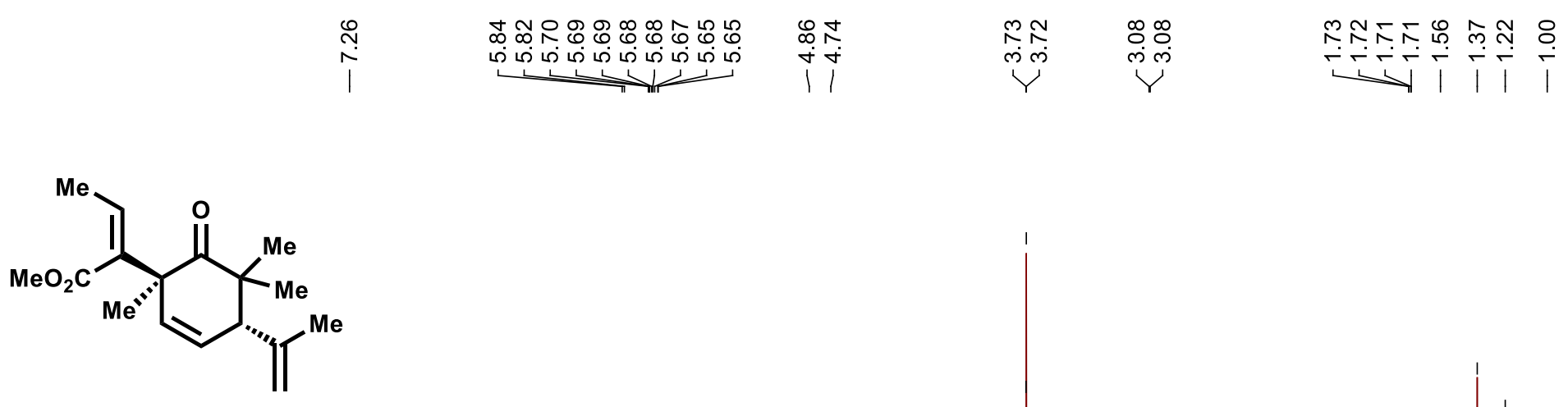

${ }^{1} \mathrm{H} \mathrm{NMR}, \mathrm{CDCl}_{3}, 600 \mathrm{MHz}$

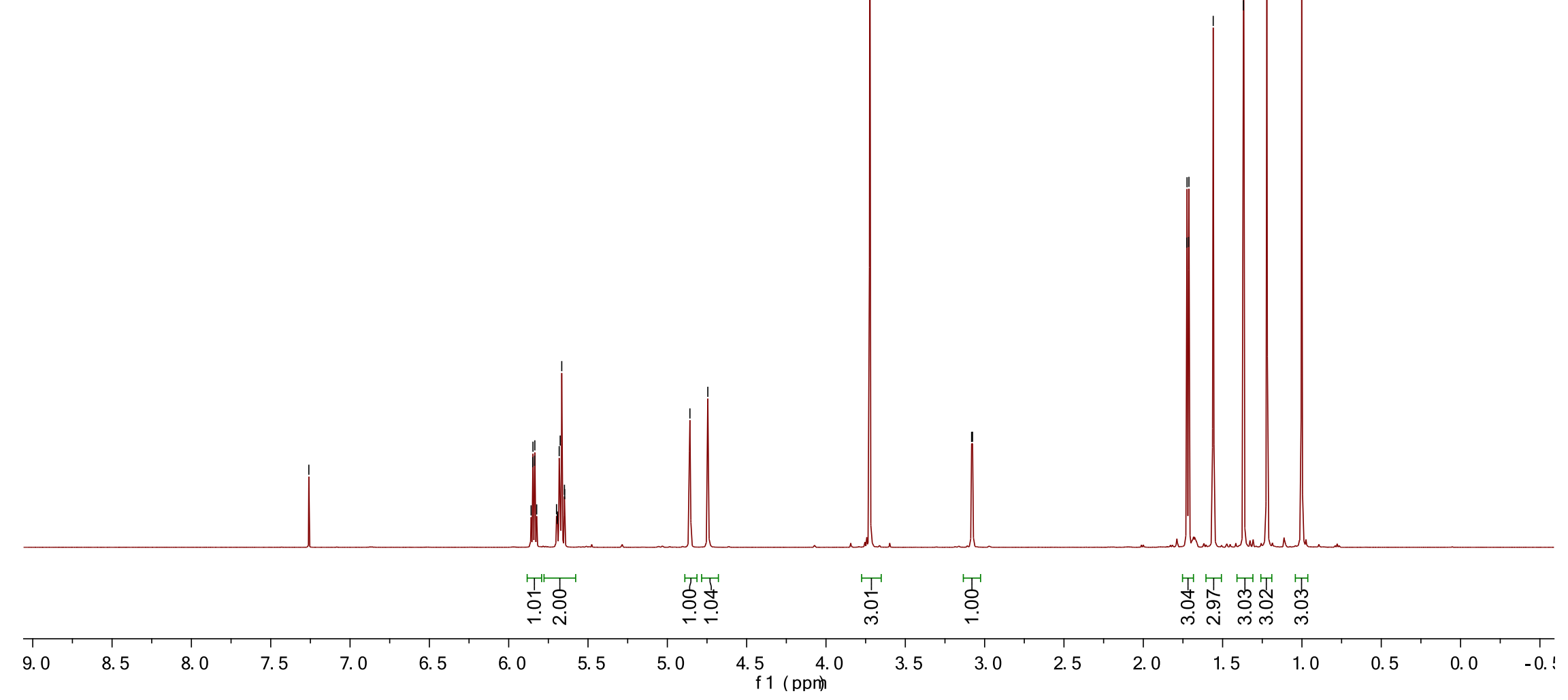




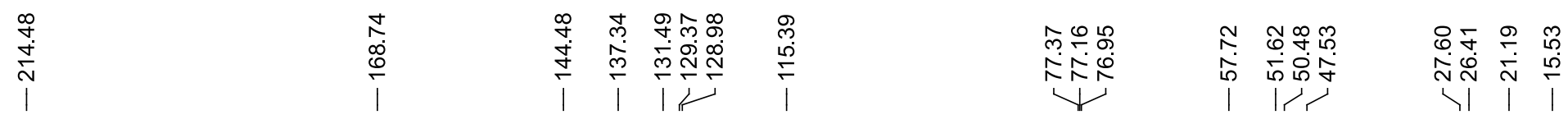

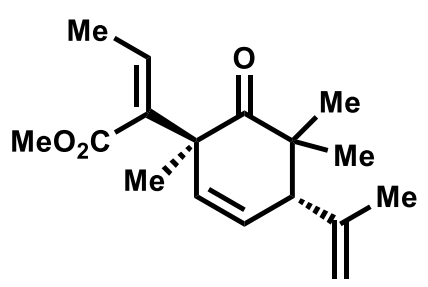

${ }^{13} \mathrm{C} \mathrm{NMR}, \mathrm{CDCl}_{3}, 150 \mathrm{MHz}$

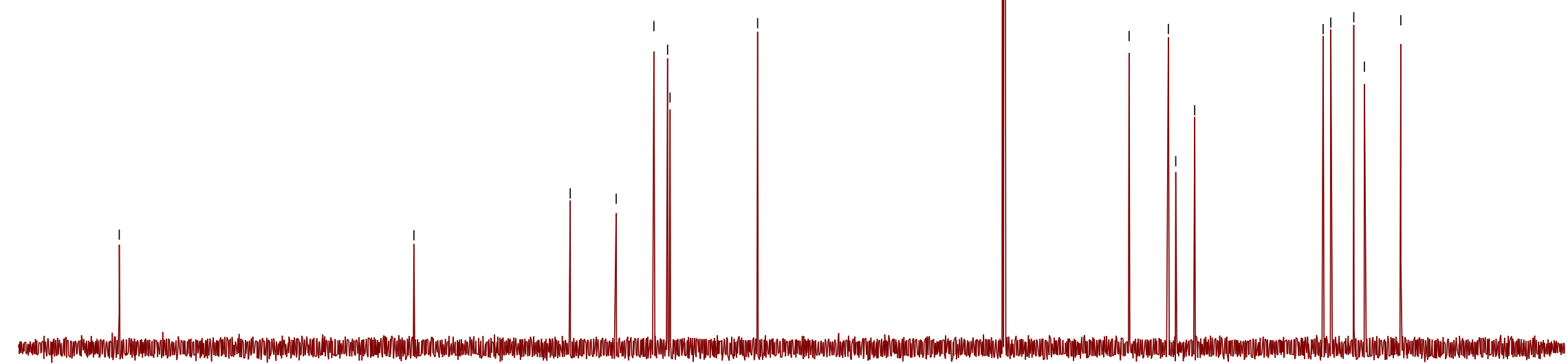

$30 \quad 220$

$210 \quad 200$

190

180

160

150

130

$120 \quad 110$

$\mathrm{f} 1$ (ppn) 


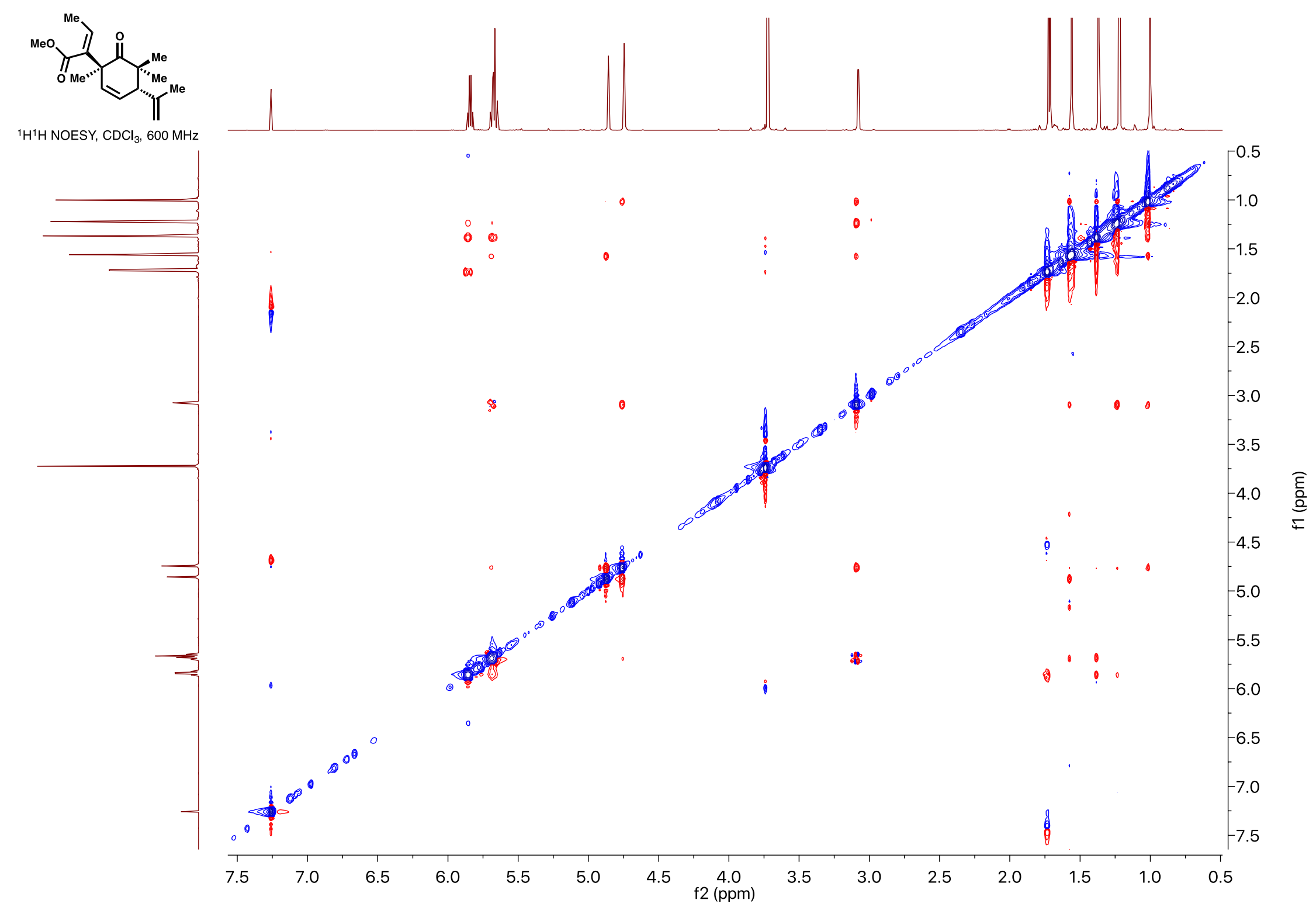




$$
\text { in }
$$

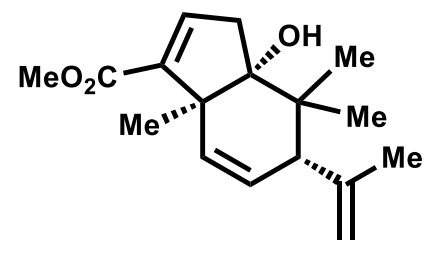

${ }^{1} \mathrm{H} \mathrm{NMR}, \mathrm{CDCl}_{3}, 600 \mathrm{MHz}$

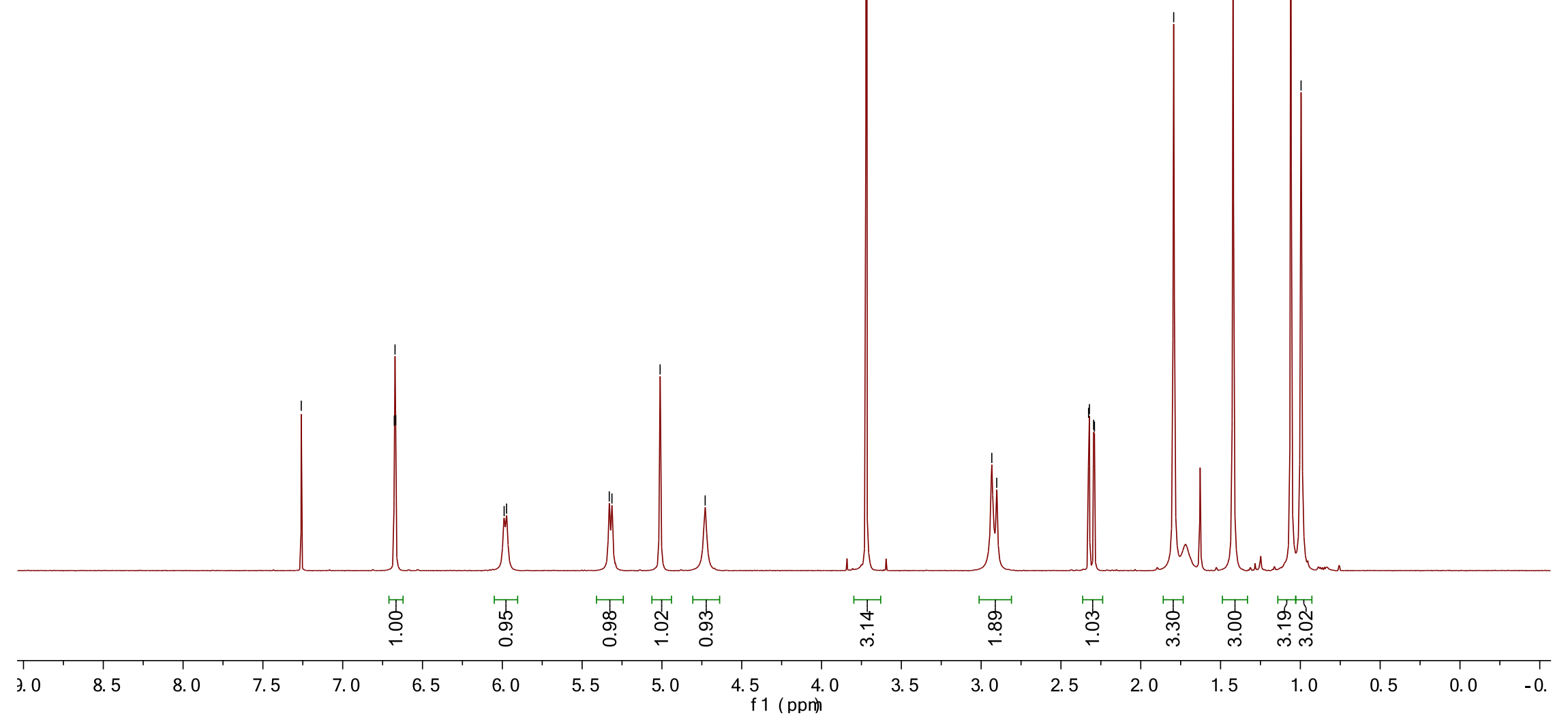




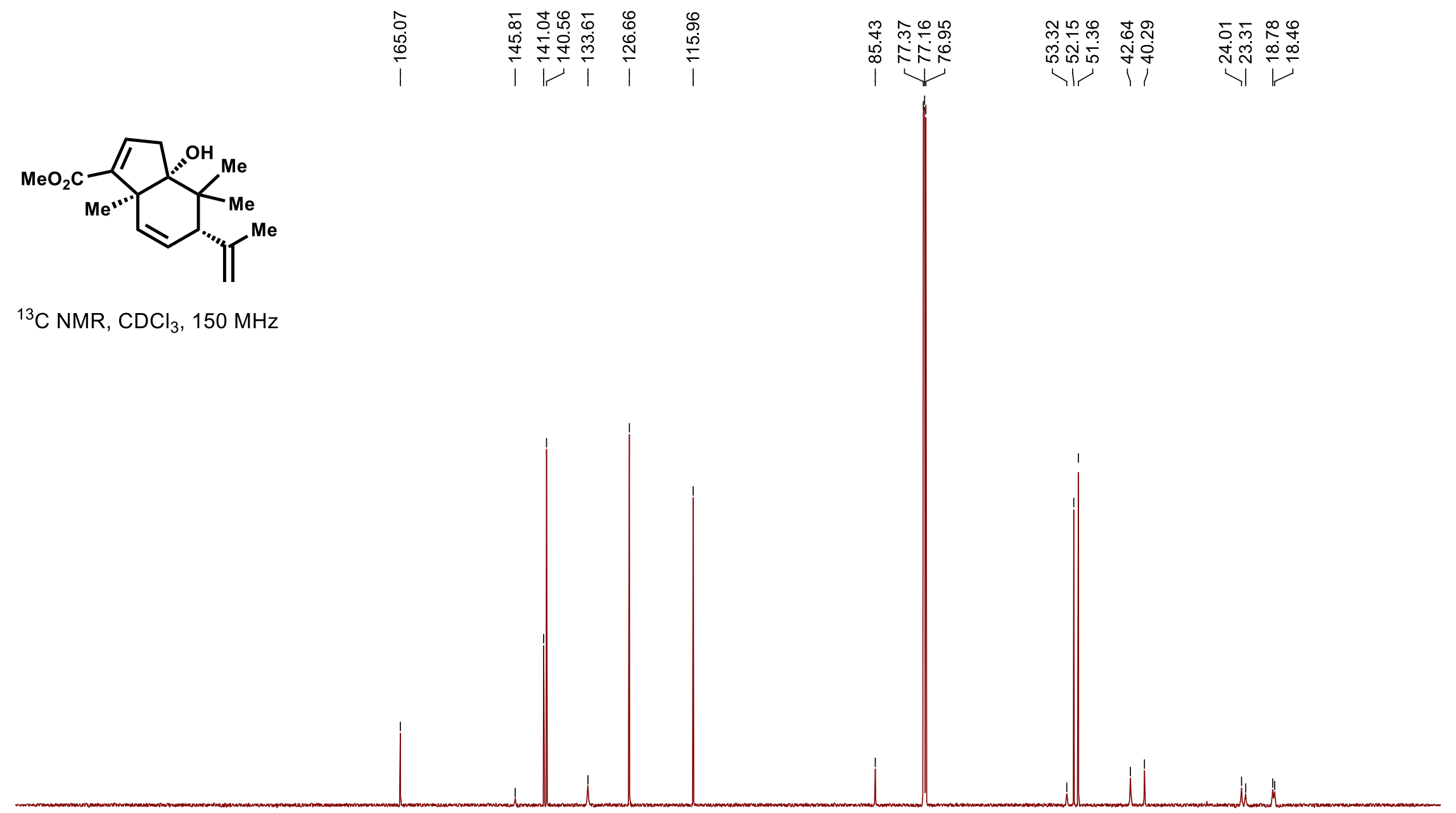




\section{ำ \\ i}

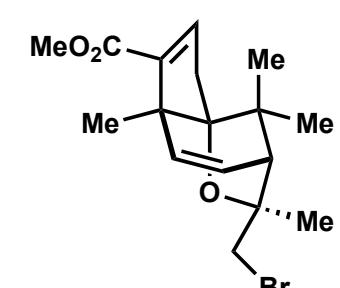

${ }^{1} \mathrm{H} \mathrm{NMR}, \mathrm{CDCl}_{3}, 600 \mathrm{MHz}$

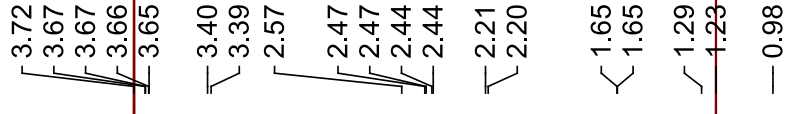

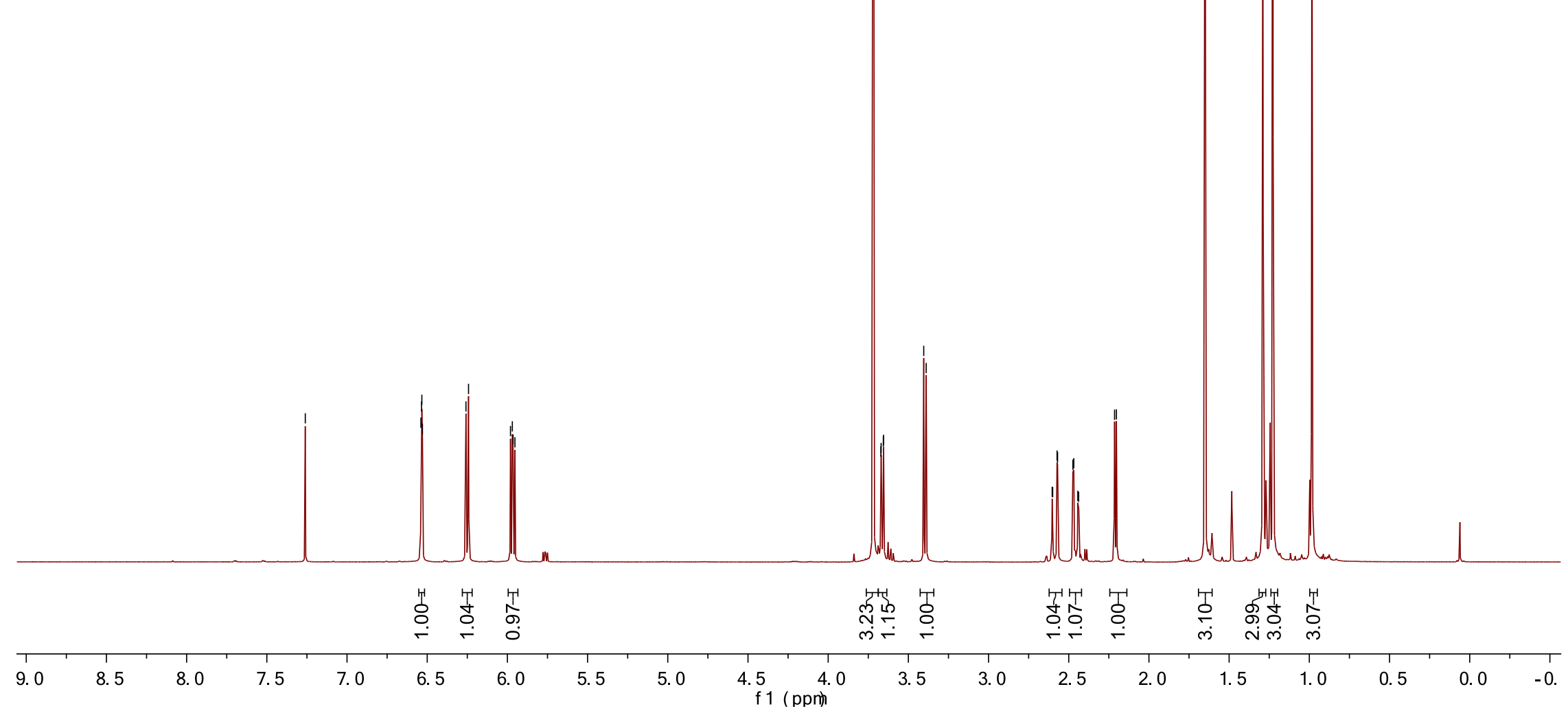




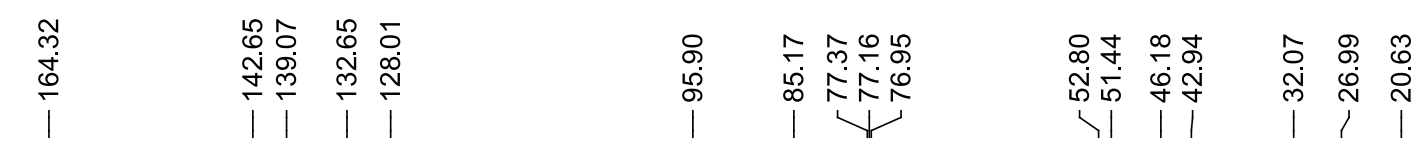

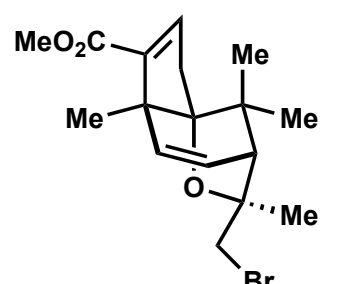

${ }^{13} \mathrm{C} \mathrm{NMR}, \mathrm{CDCl}_{3}, 150 \mathrm{MHz}$

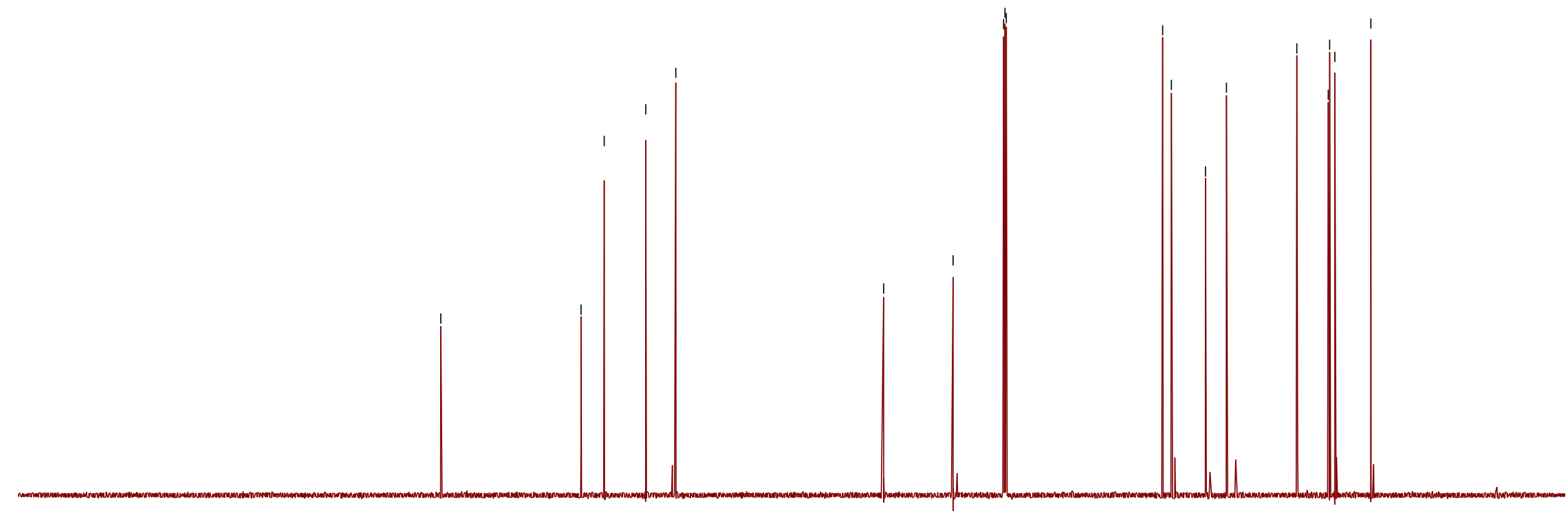



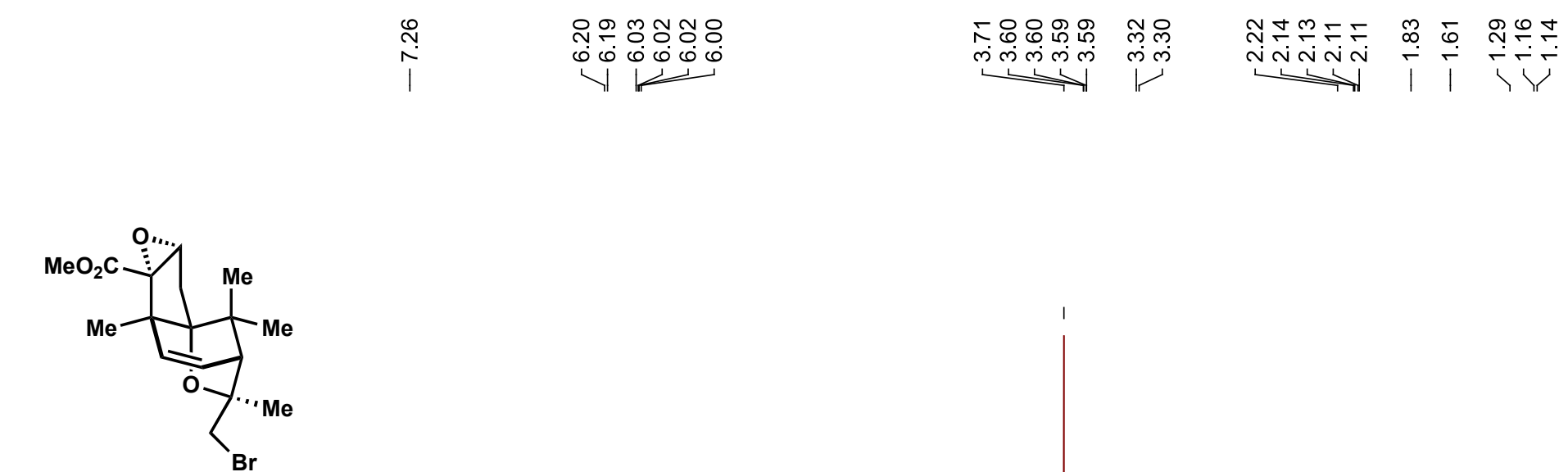

${ }^{1} \mathrm{H} \mathrm{NMR}, \mathrm{CDCl}_{3}, 600 \mathrm{MHz}$

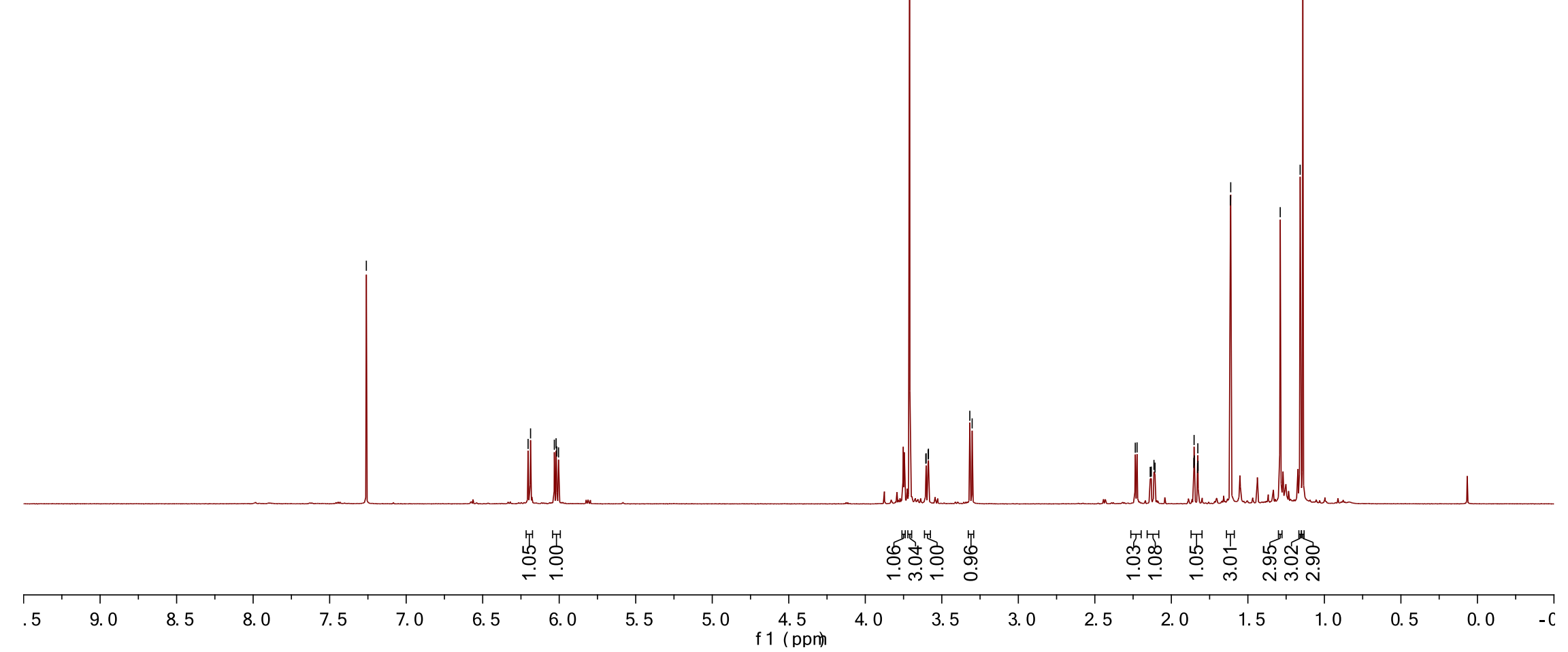




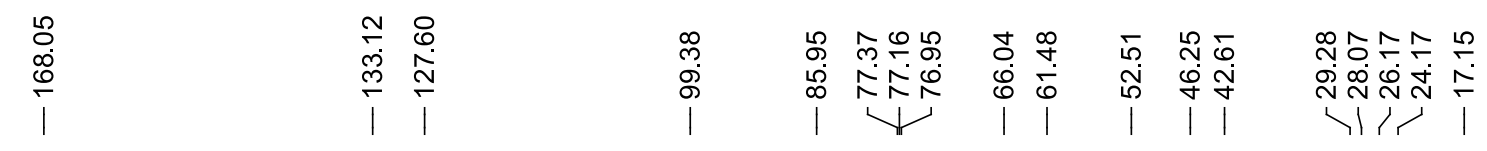

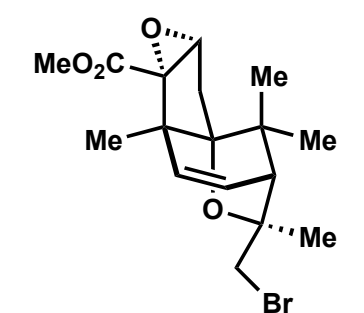

${ }^{13} \mathrm{C} \mathrm{NMR}, \mathrm{CDCl}_{3}, 150 \mathrm{MHz}$

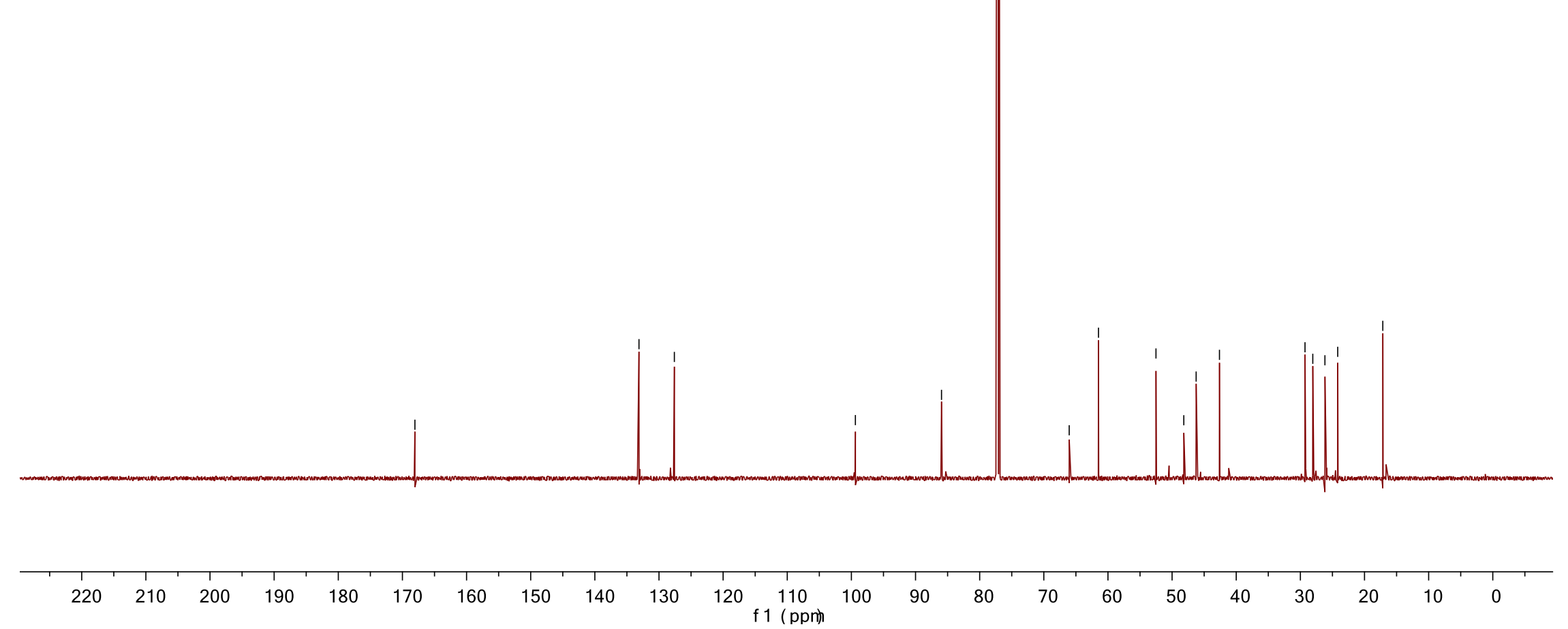




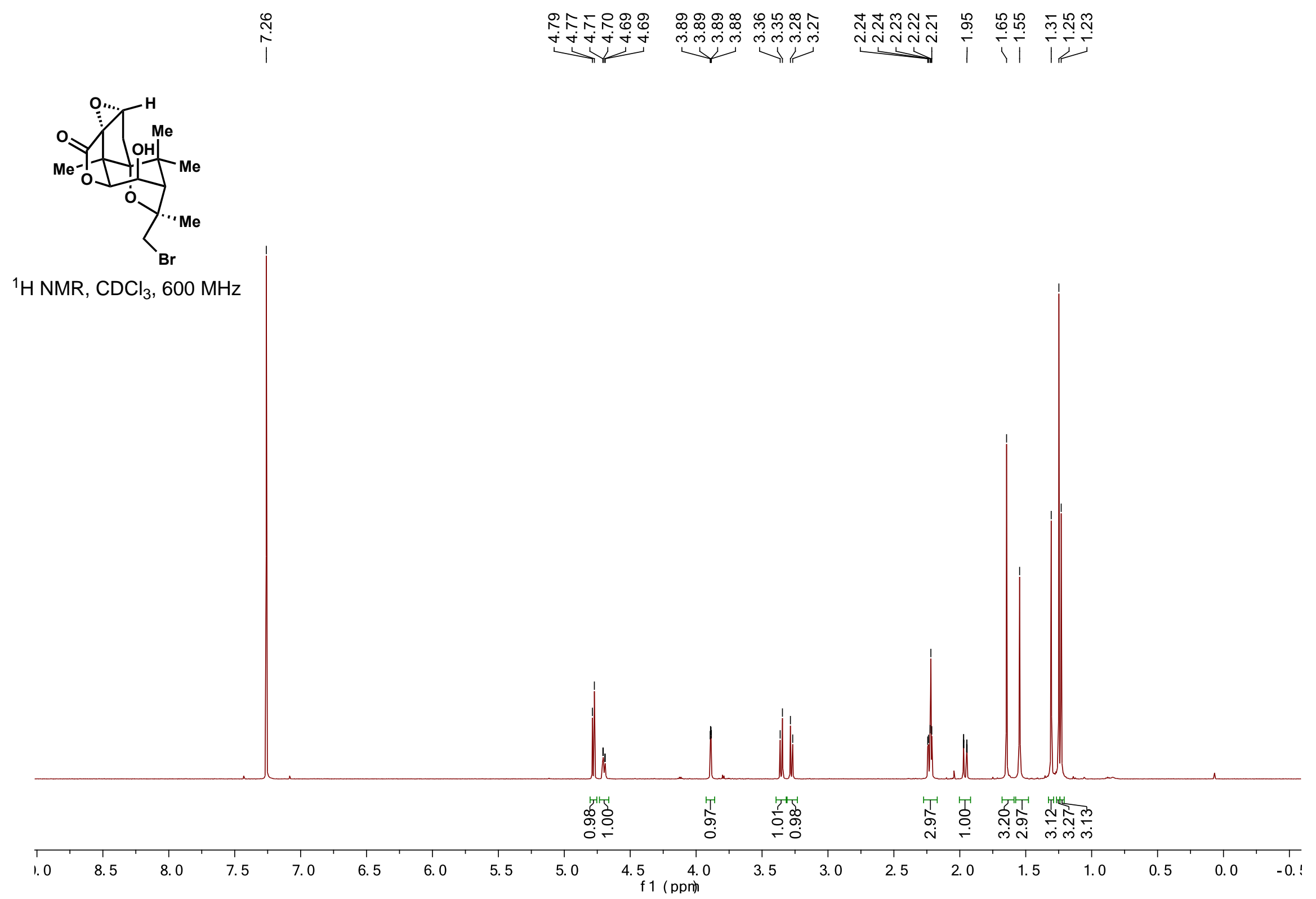




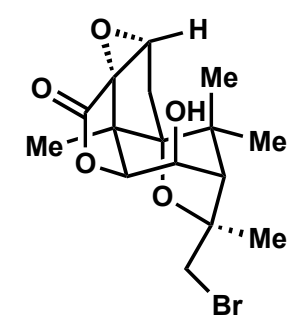

${ }^{13} \mathrm{C} \mathrm{NMR}, \mathrm{CDCl}_{3}, 150 \mathrm{MHz}$

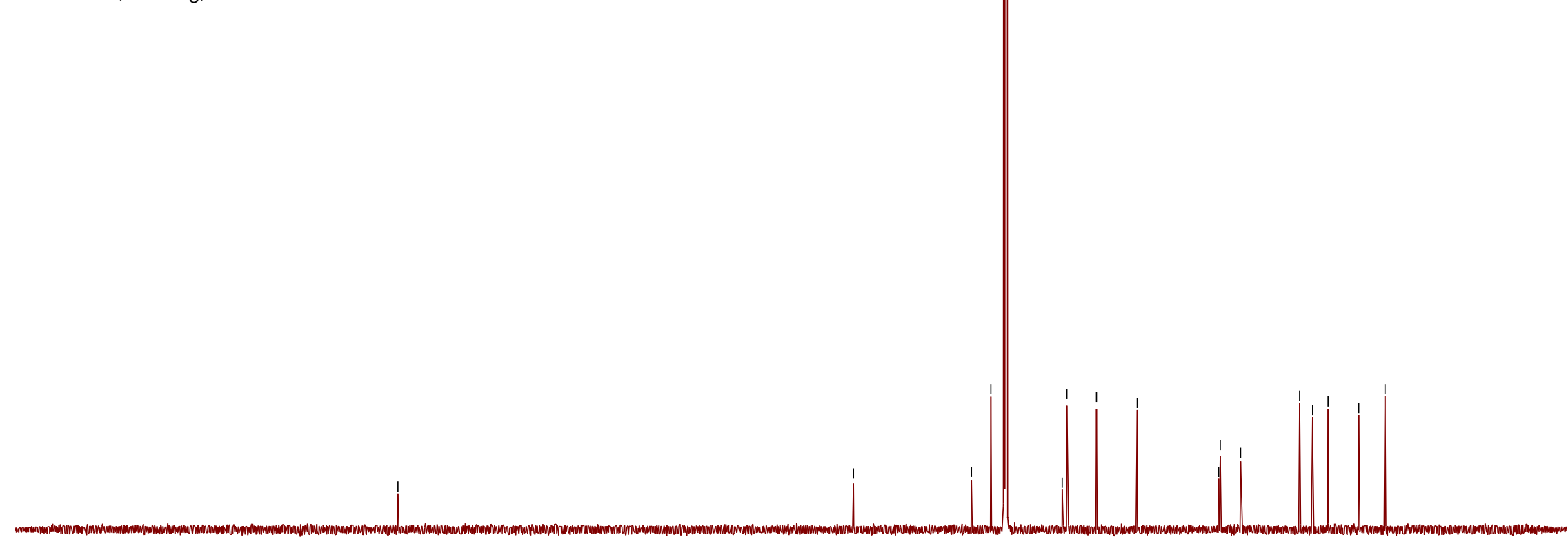

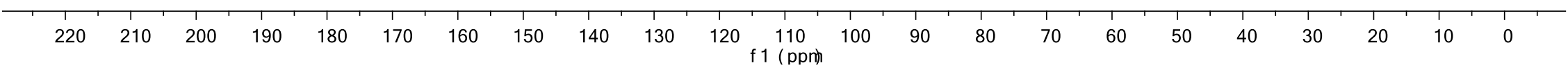




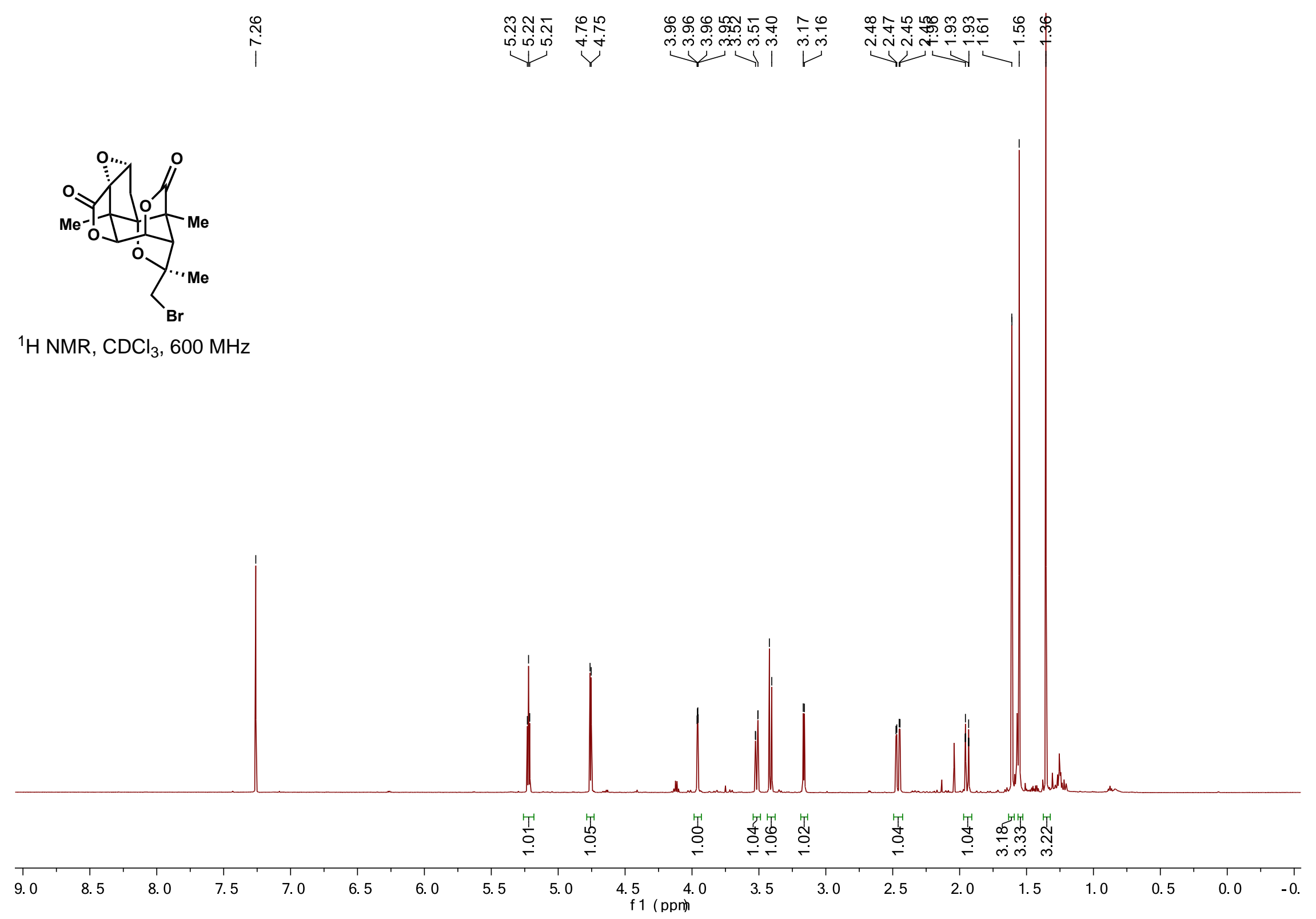




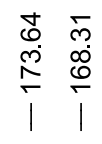

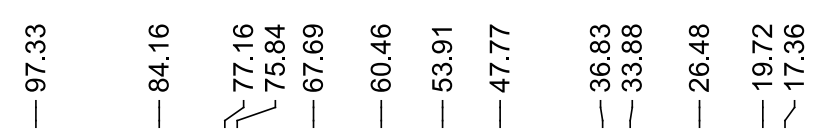

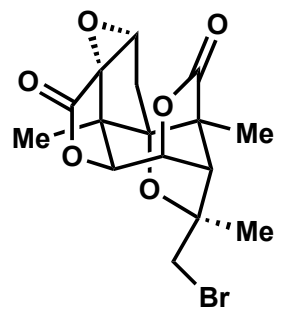

${ }^{13} \mathrm{C} \mathrm{NMR}, \mathrm{CDCl}_{3}, 150 \mathrm{MHz}$

NMR,

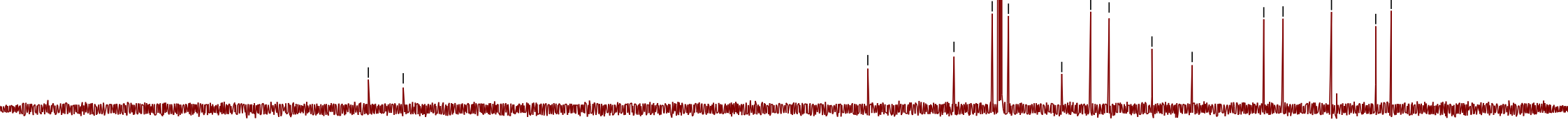

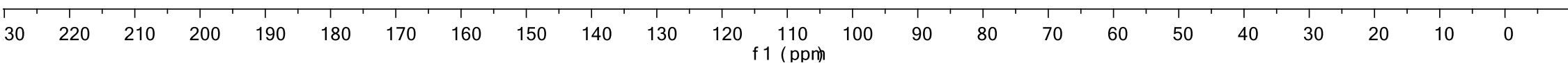



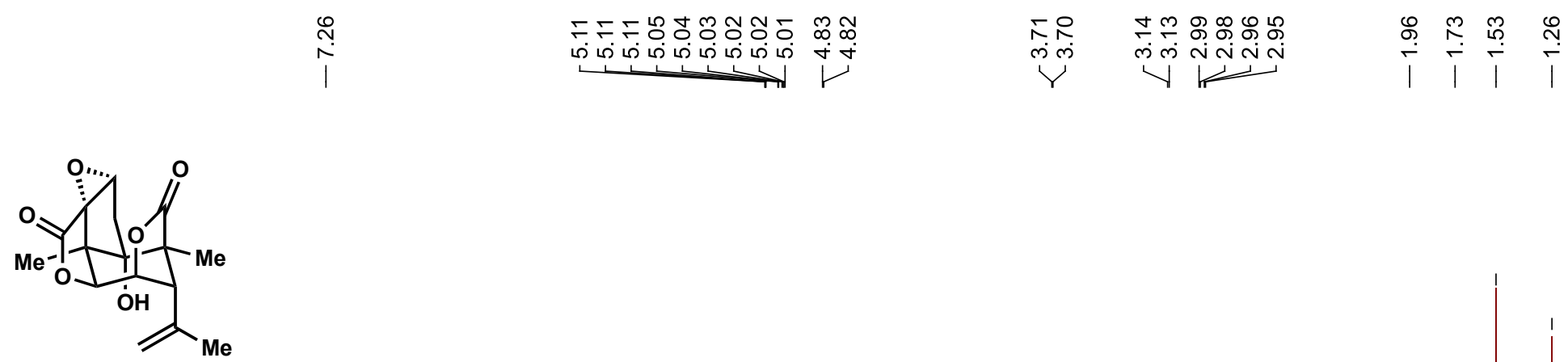

${ }^{1} \mathrm{HNMR}, \mathrm{CDCl}_{3}, 600 \mathrm{MHz}$

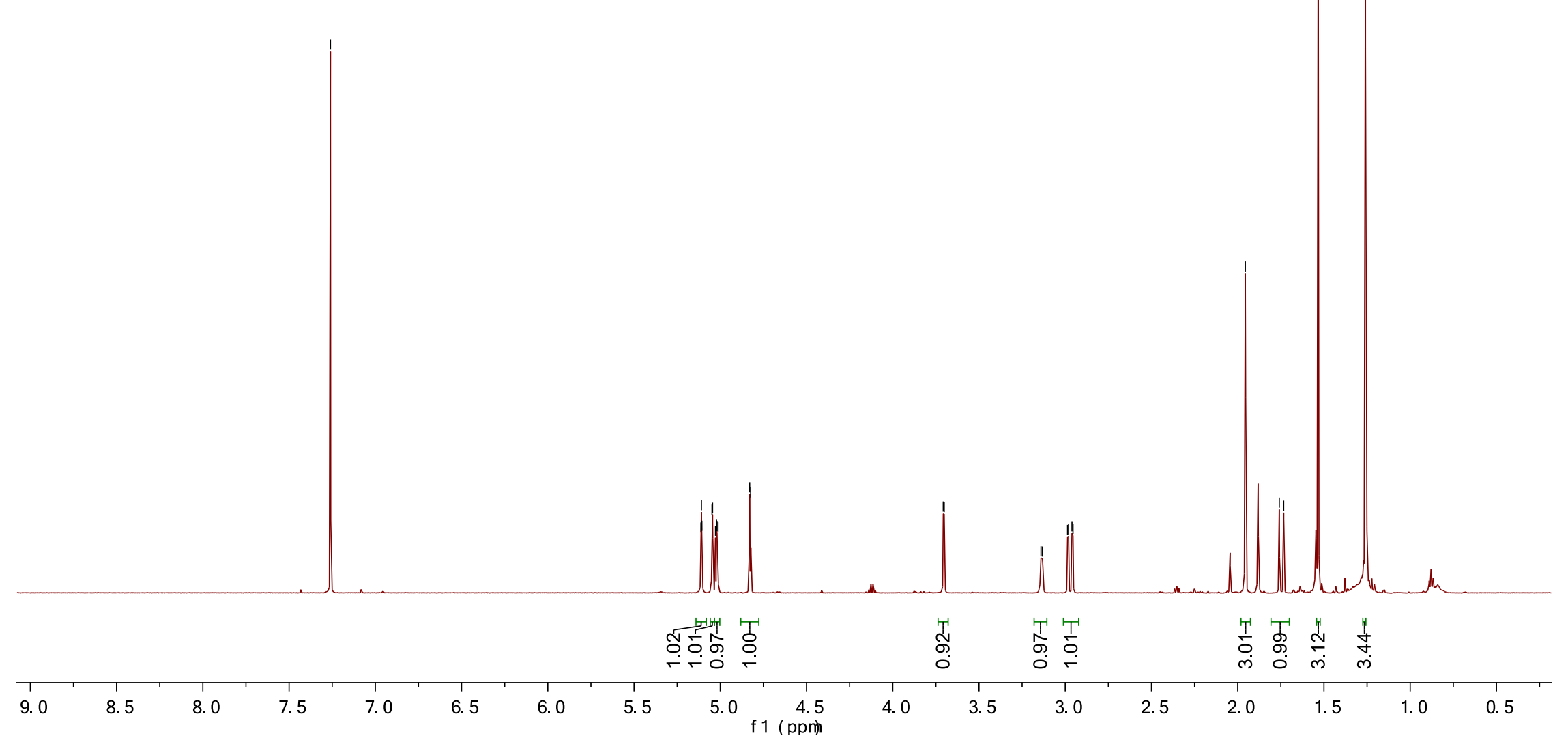




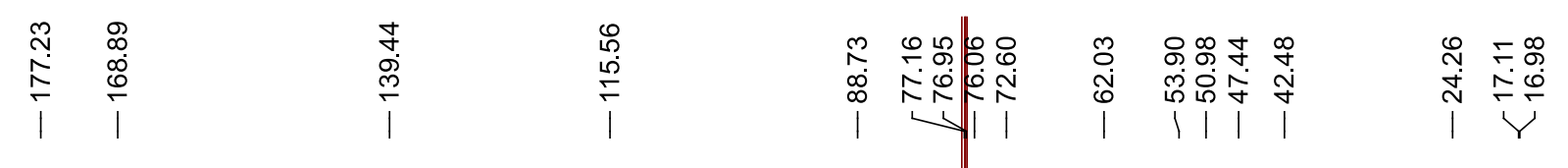

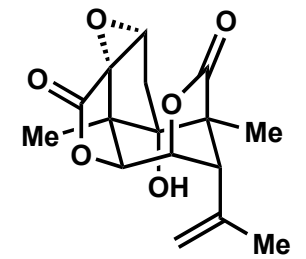

${ }^{13} \mathrm{C}$ NMR, $\mathrm{CDCl}_{3}, 150 \mathrm{MHz}$

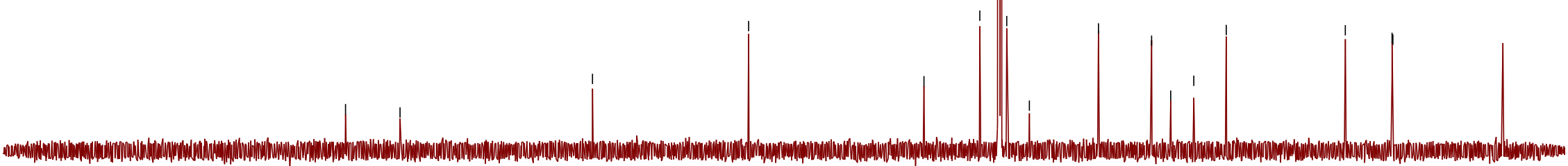

\begin{tabular}{|c|c|c|c|c|c|c|c|c|c|c|c|c|c|c|c|c|c|c|c|c|c|c|}
\hline 220 & 210 & 200 & 190 & 180 & 170 & 160 & 150 & 140 & 130 & 120 & $\begin{array}{c}110 \\
\mathrm{f} 1(\mathrm{ppm})\end{array}$ & 100 & 90 & 80 & 70 & 60 & 50 & 40 & 30 & 20 & 10 & 0 \\
\hline
\end{tabular}




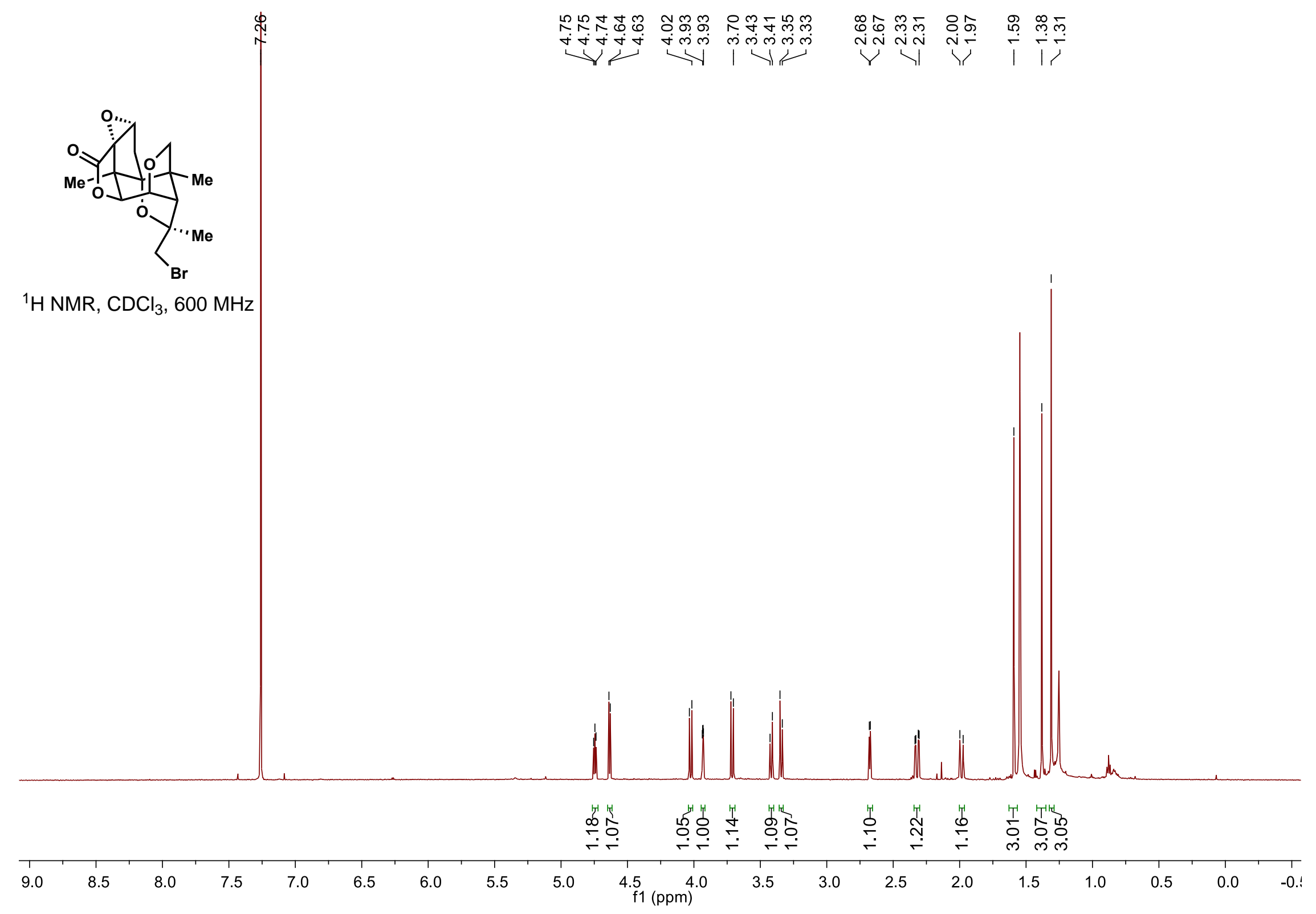




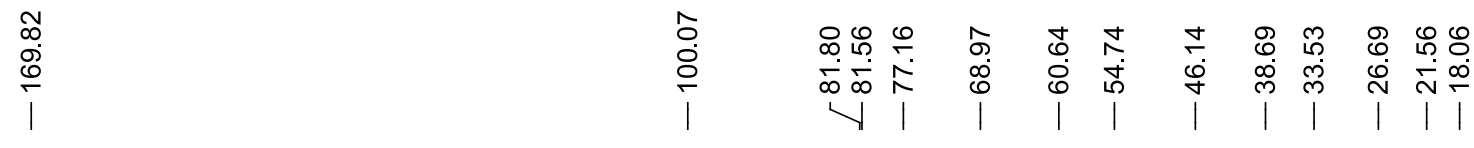

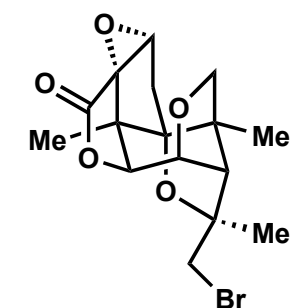

${ }^{13} \mathrm{C}$ NMR, $\mathrm{CDCl}_{3}, 150 \mathrm{MHz}$

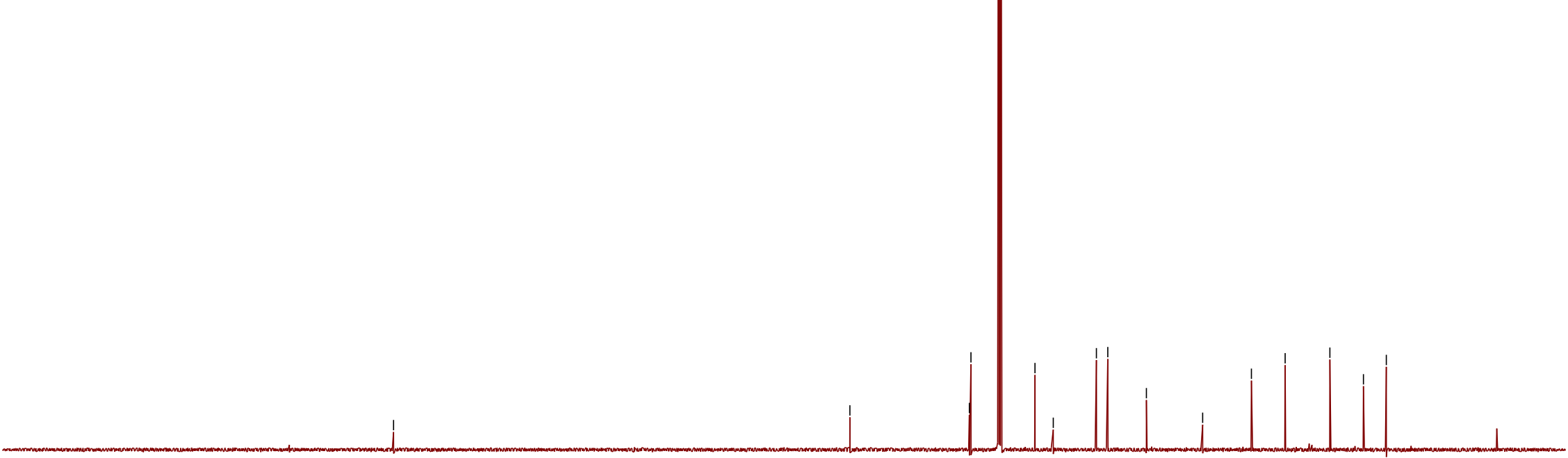




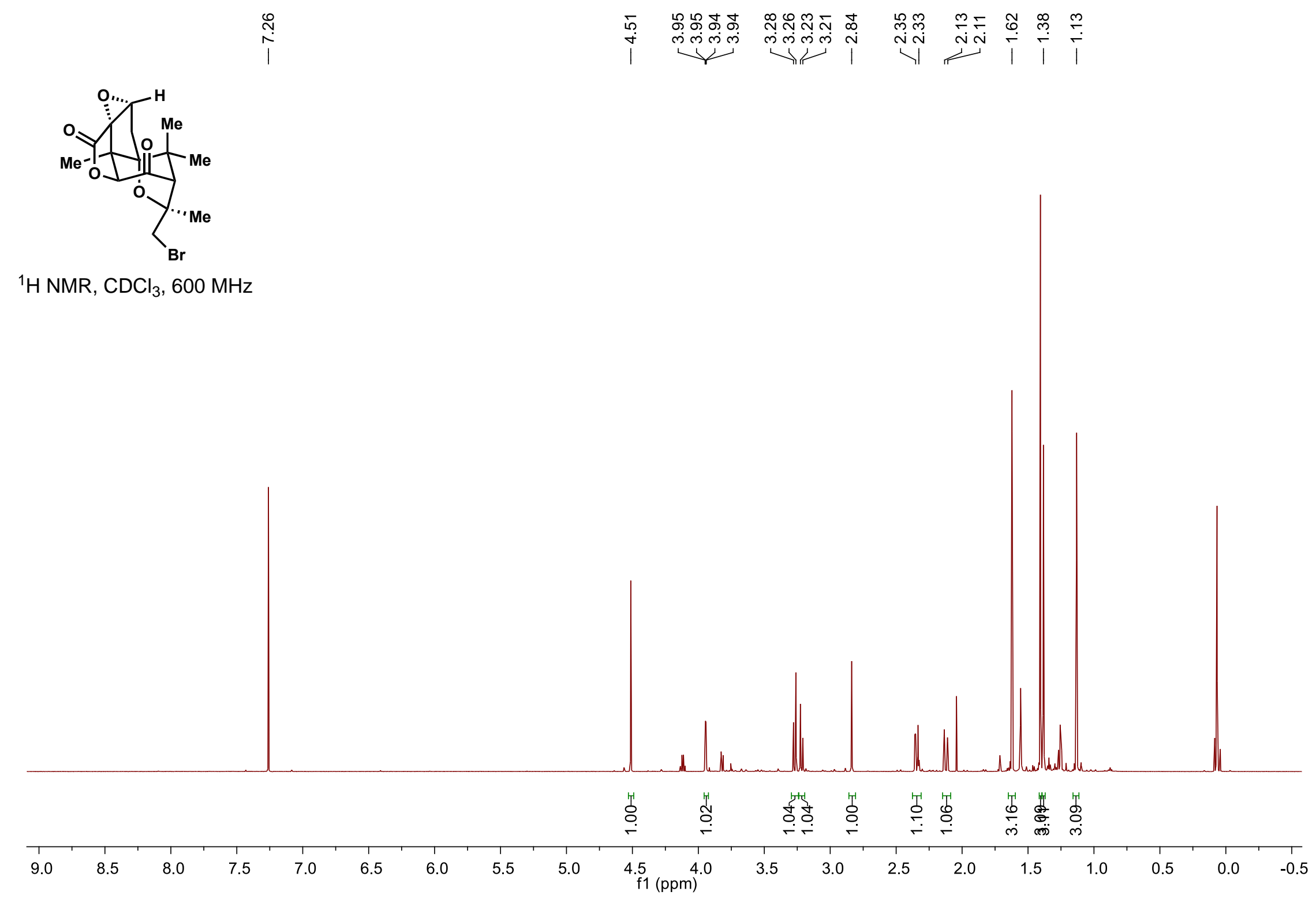




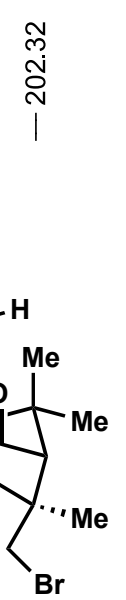

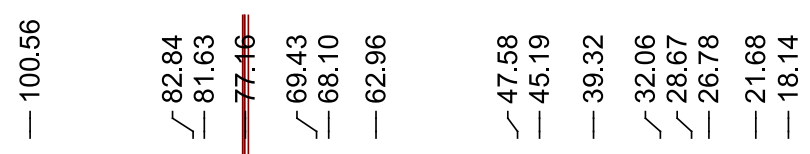

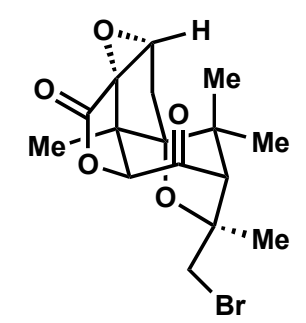

${ }^{13} \mathrm{C} \mathrm{NMR}, \mathrm{CDCl}_{3}, 150 \mathrm{MHz}$
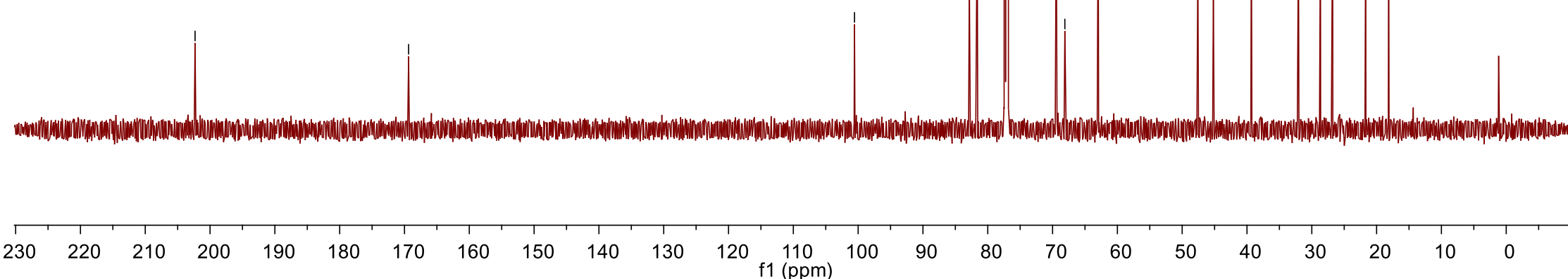


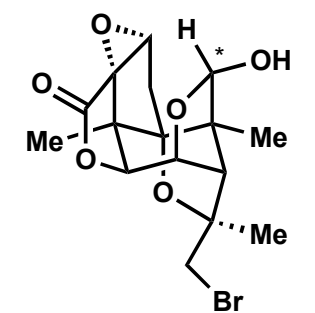

*2.5:1 d.r., major shown ${ }^{1} \mathrm{H} \mathrm{NMR}, \mathrm{CDCl}_{3}, 600 \mathrm{MHz}$

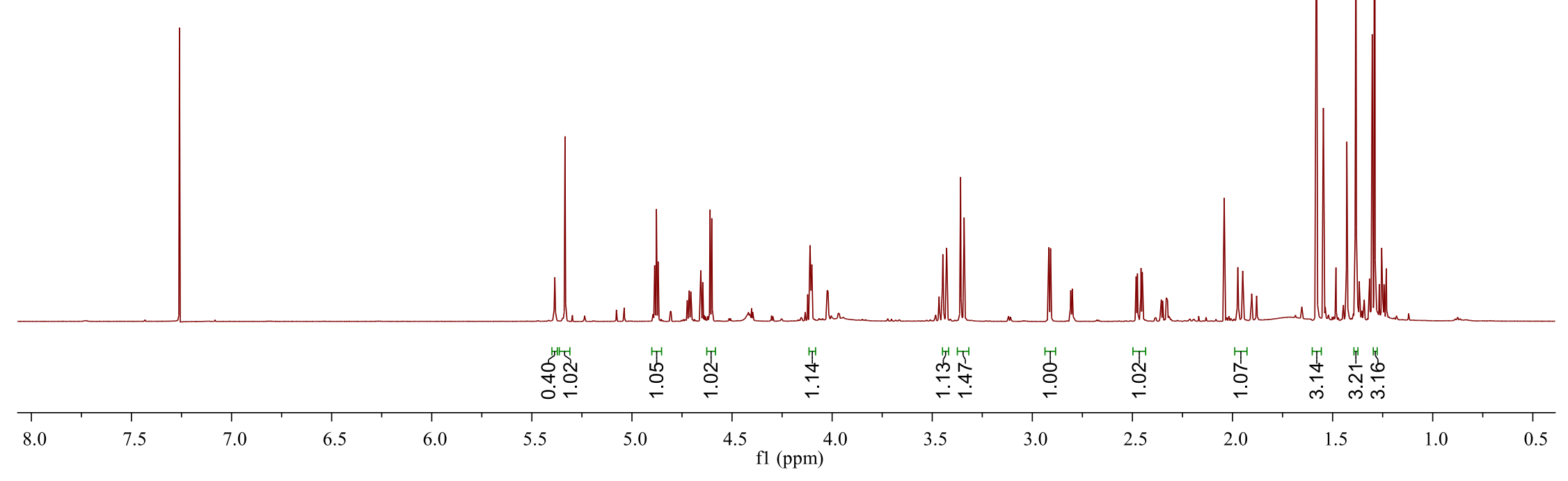




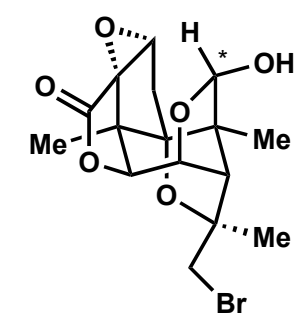

*2.5:1 d.r., major shown

${ }^{13} \mathrm{C} \mathrm{NMR}, \mathrm{CDCl}_{3}, 150 \mathrm{MHz}$

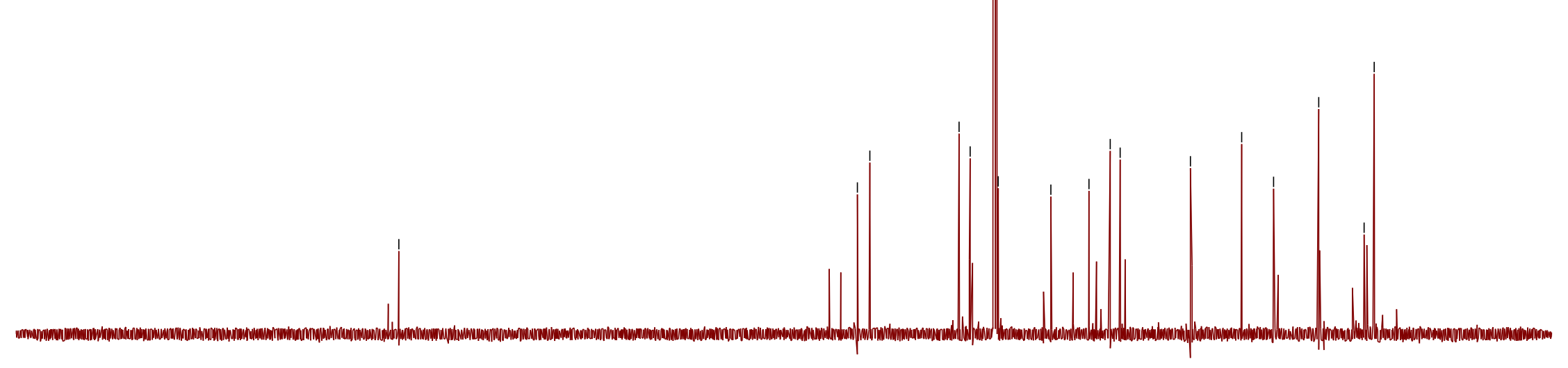




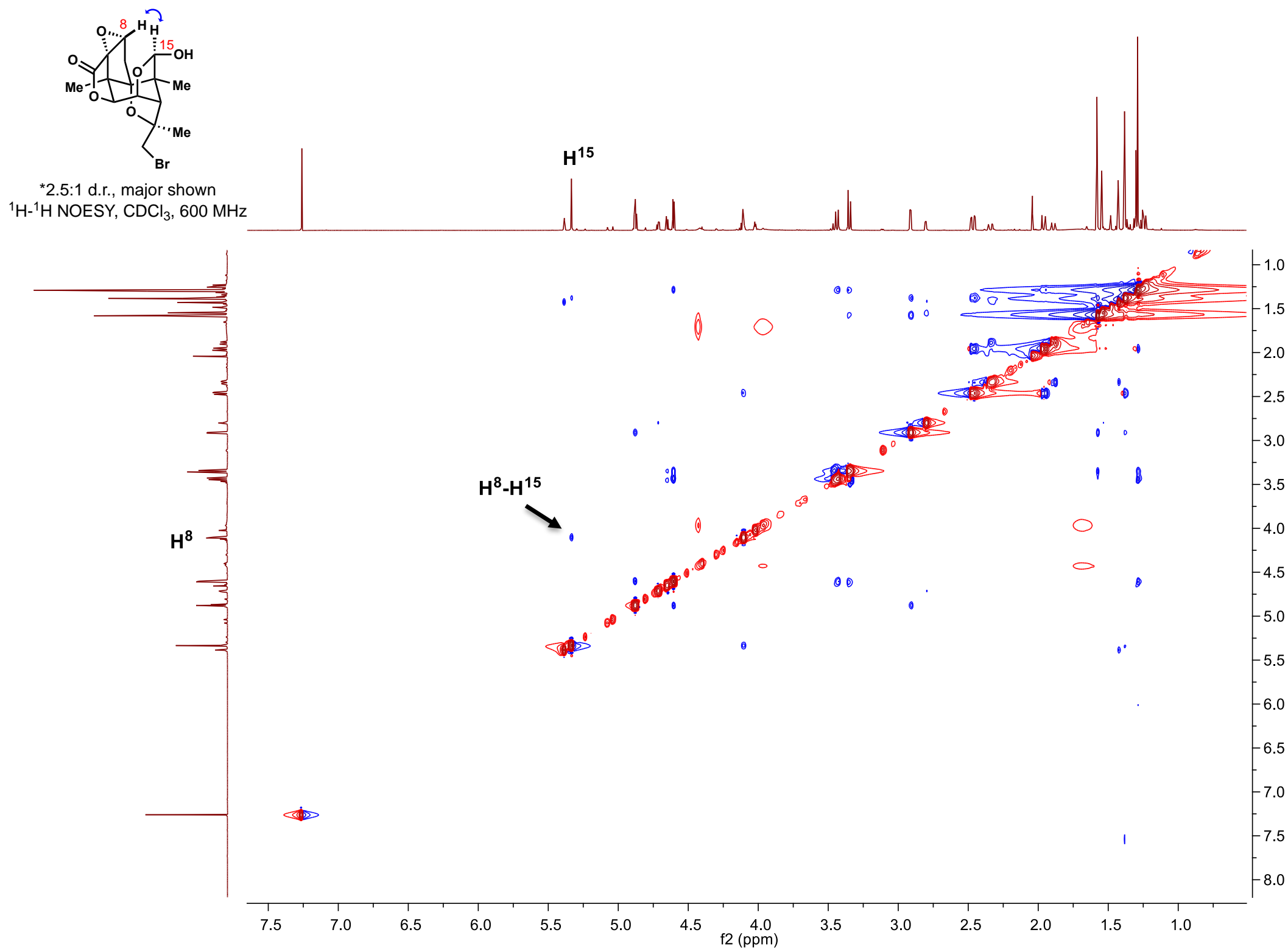




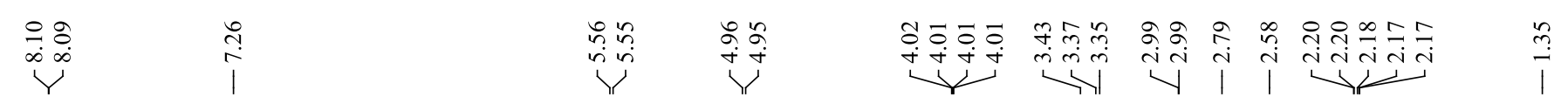

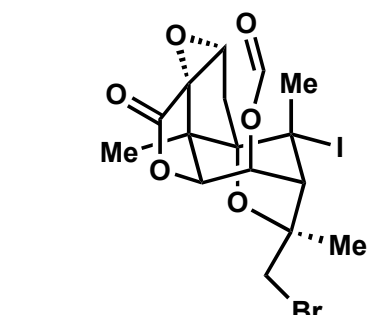

${ }^{1} \mathrm{H} \mathrm{NMR}, \mathrm{CDCl}_{3}, 600 \mathrm{MHz}$

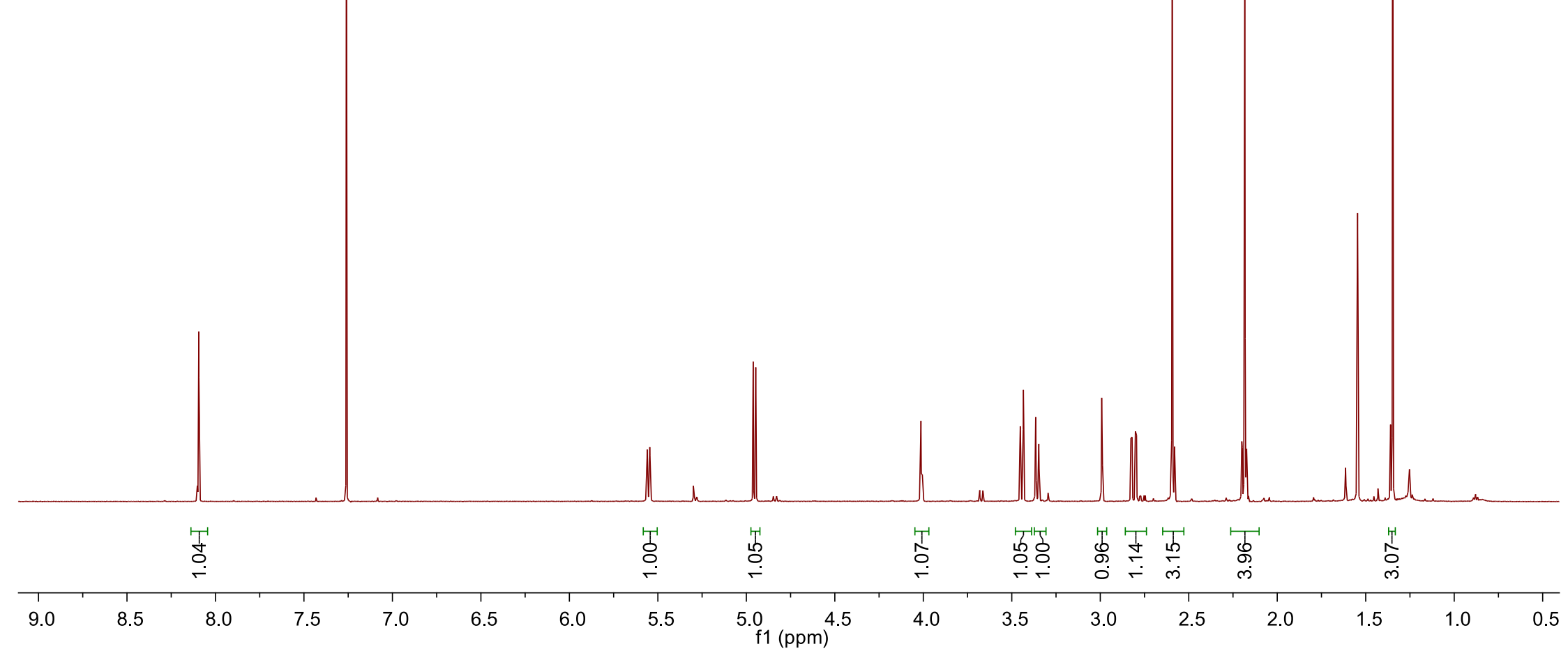




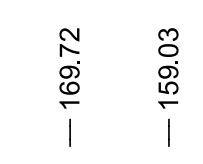

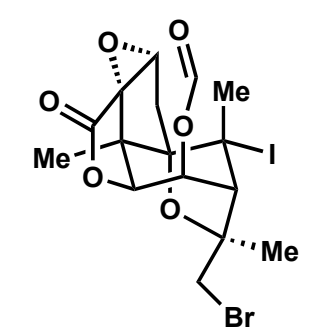

${ }^{13} \mathrm{C} \mathrm{NMR}, \mathrm{CDCl}_{3}, 150 \mathrm{MHz}$

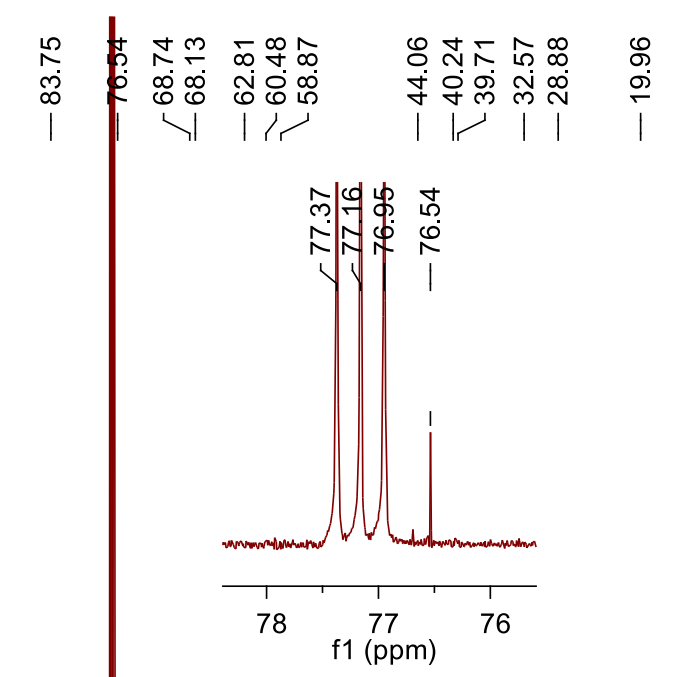

$\begin{array}{lllllll}220 & 210 & 200 & 190 & 180 & 170 & 160\end{array}$

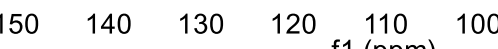

f1 $(\mathrm{ppm})$
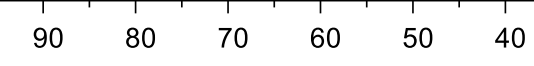

30

20 


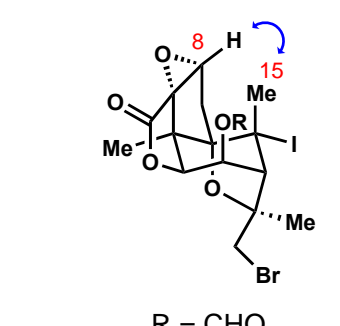

${ }^{1} \mathrm{H}-{ }^{1} \mathrm{H}$ NOESY, $\mathrm{CDCl}_{3}, 600 \mathrm{MHz}$

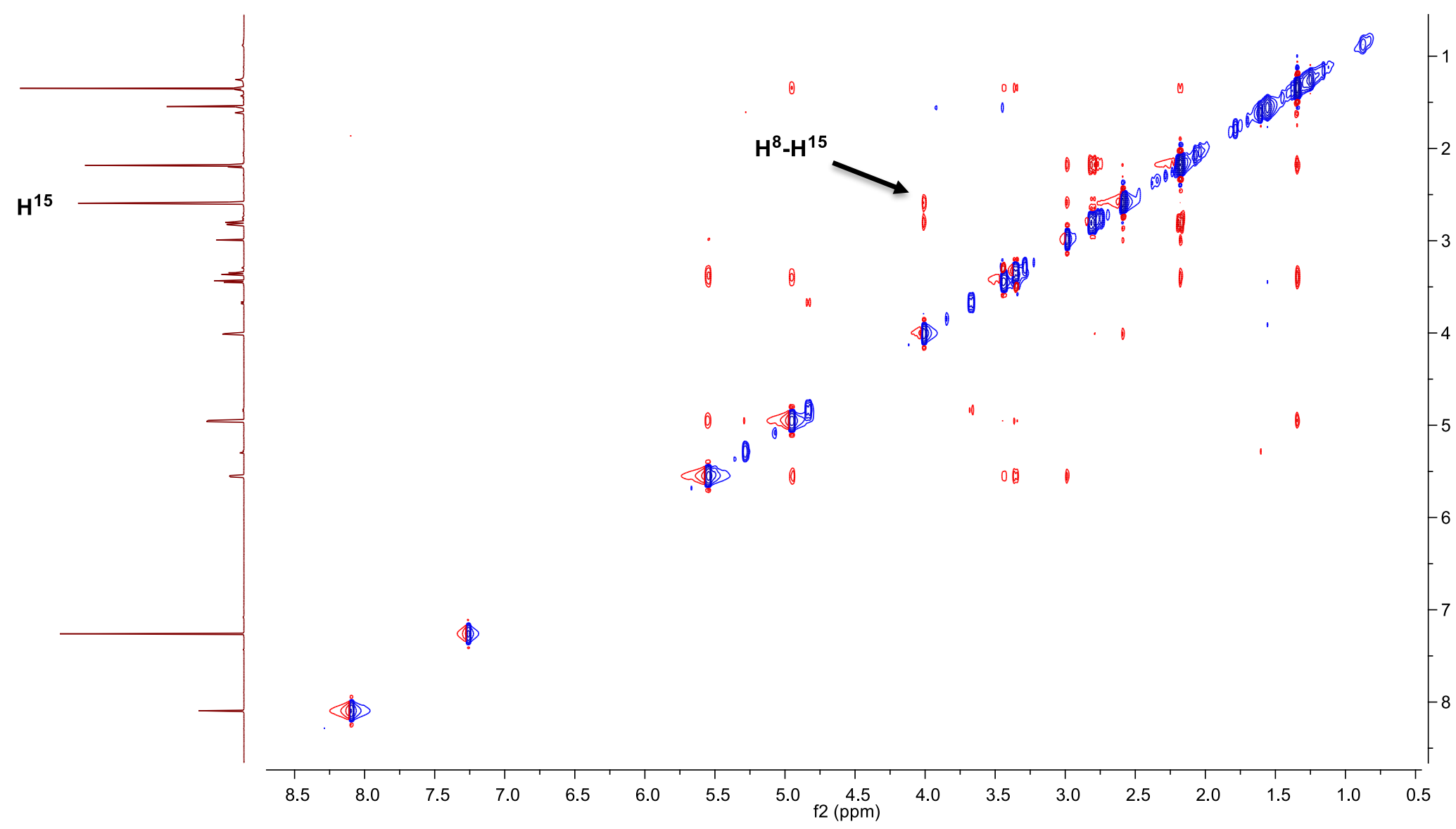

$\underset{\underline{E}}{\stackrel{\bar{a}}{a}}$ 


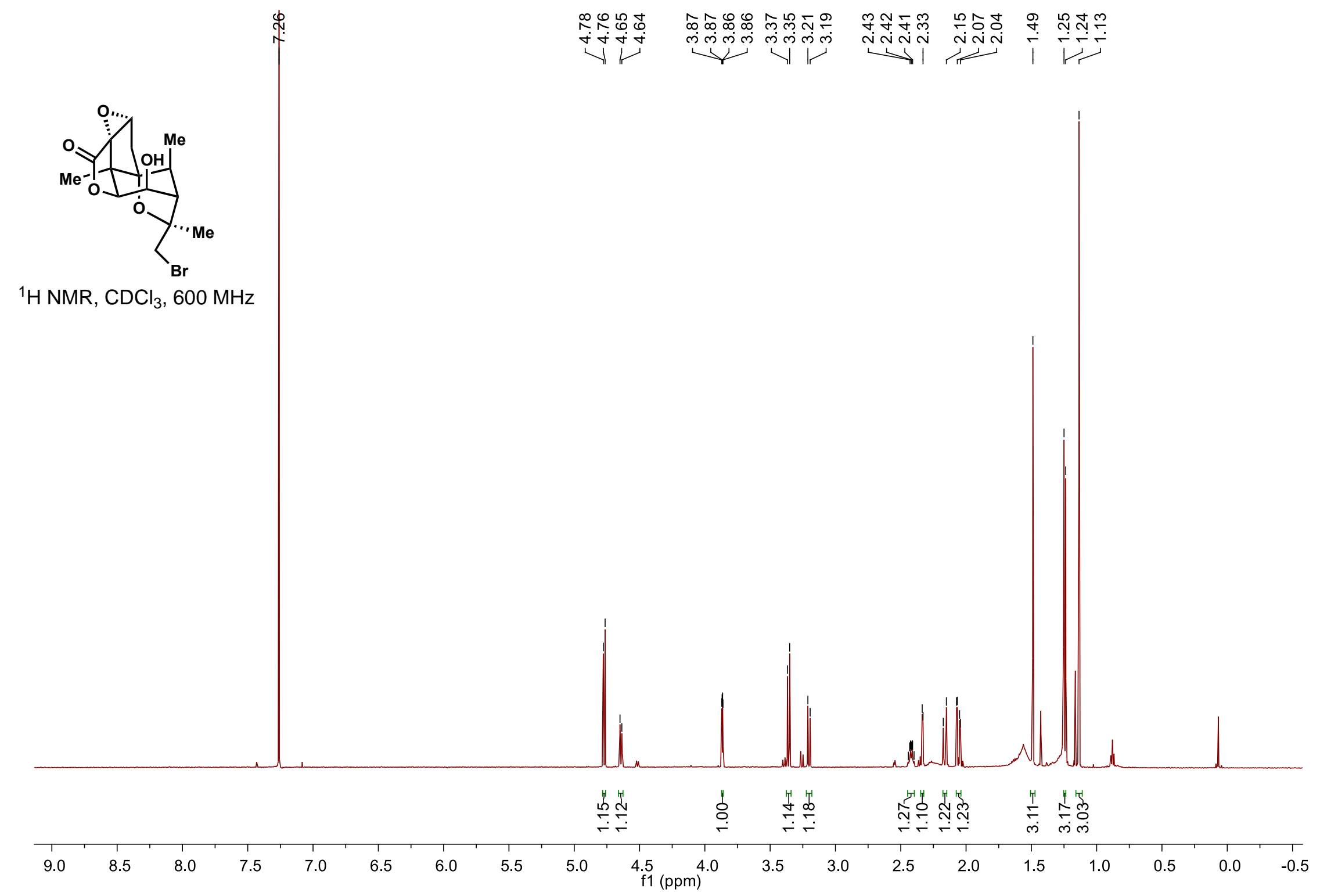




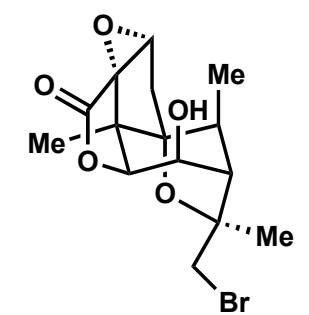

${ }^{13} \mathrm{C} \mathrm{NMR}, \mathrm{CDCl}_{3}, 150 \mathrm{MHz}$

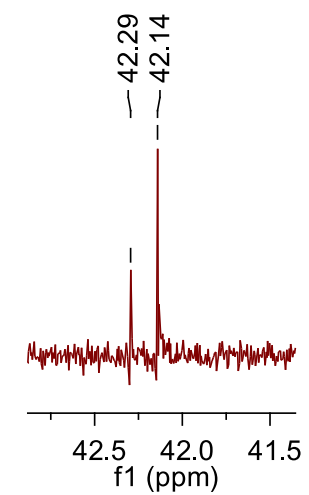

$\begin{array}{lllllllllllllllllllllll}220 & 210 & 200 & 190 & 180 & 170 & 160 & 150 & 140 & 130 & 120 & 110 & 100 & 90 & 80 & 70 & 60 & 50 & 40 & 30 & 20 & 10 & 0\end{array}$ 


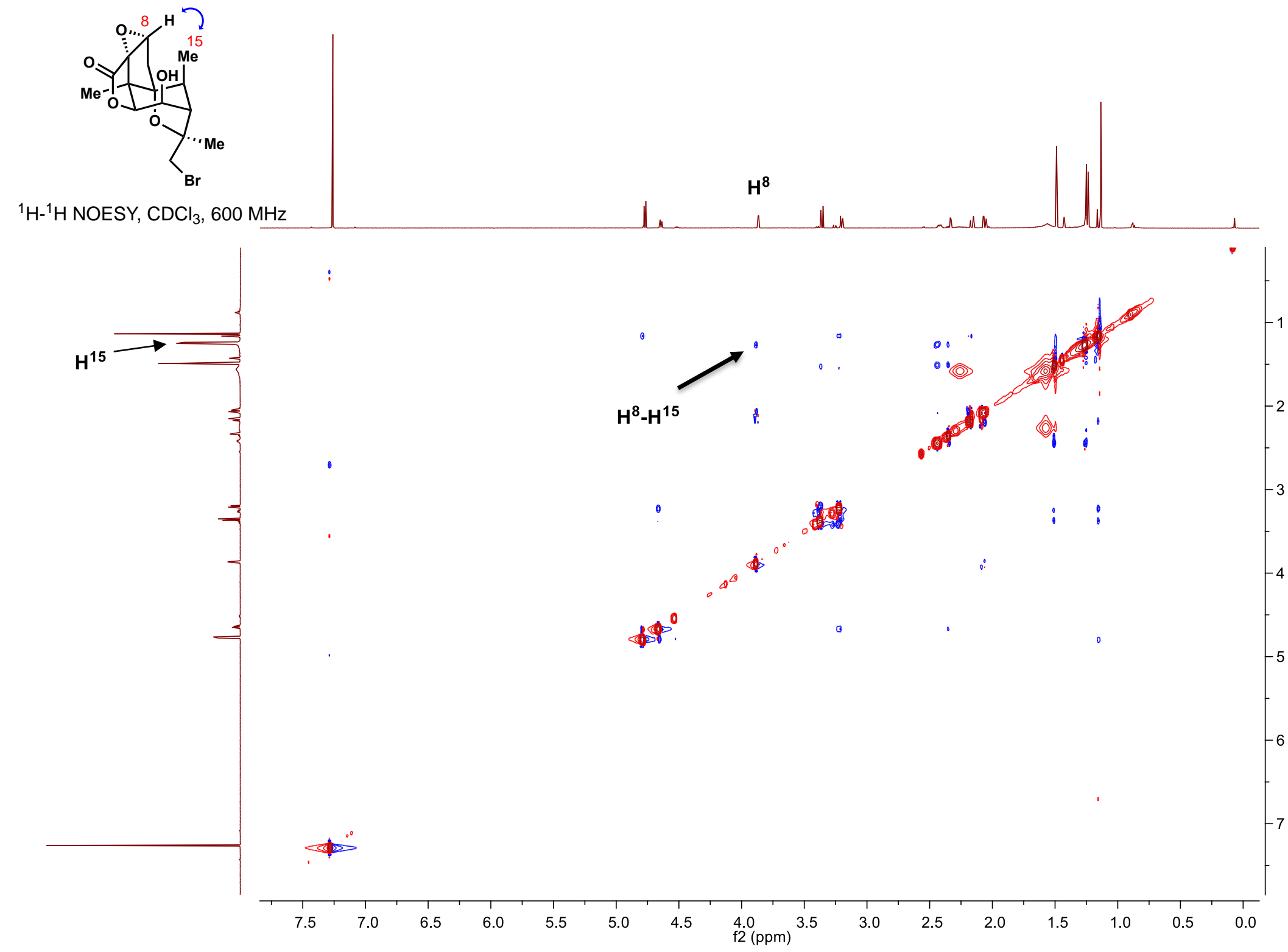

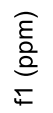




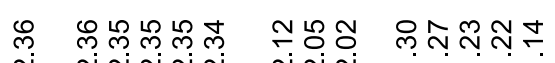

ก Ninni

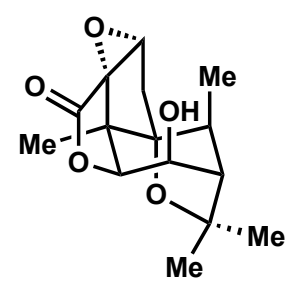

${ }^{1} \mathrm{H} \mathrm{NMR}, \mathrm{CDCl}_{3}, 600 \mathrm{MHz}$

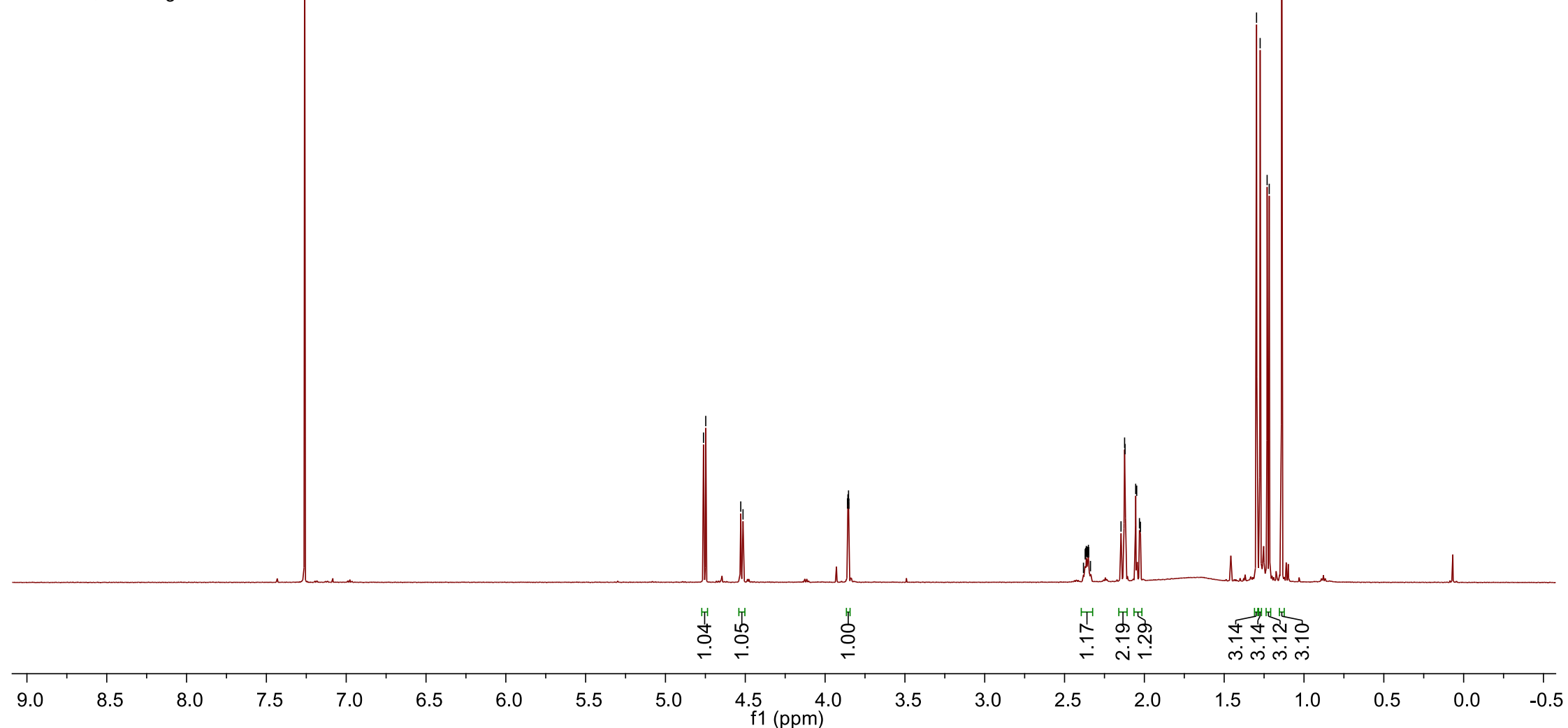




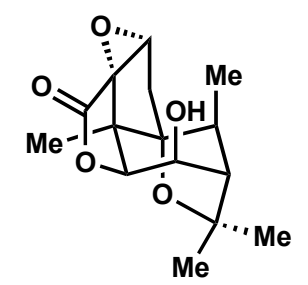

${ }^{13} \mathrm{C}$ NMR, $\mathrm{CDCl}_{3}, 150 \mathrm{MHz}$
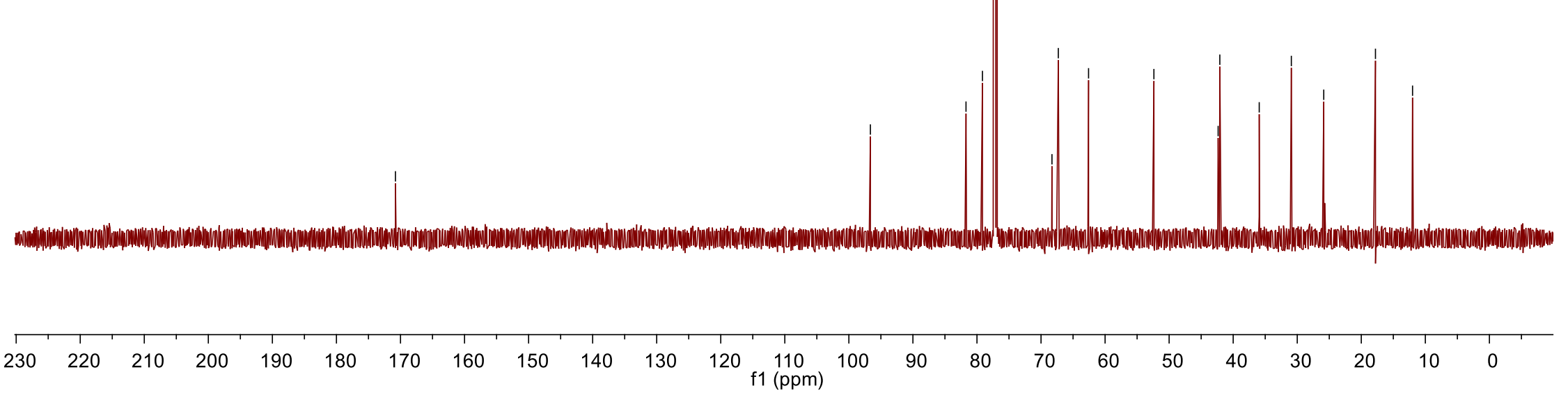


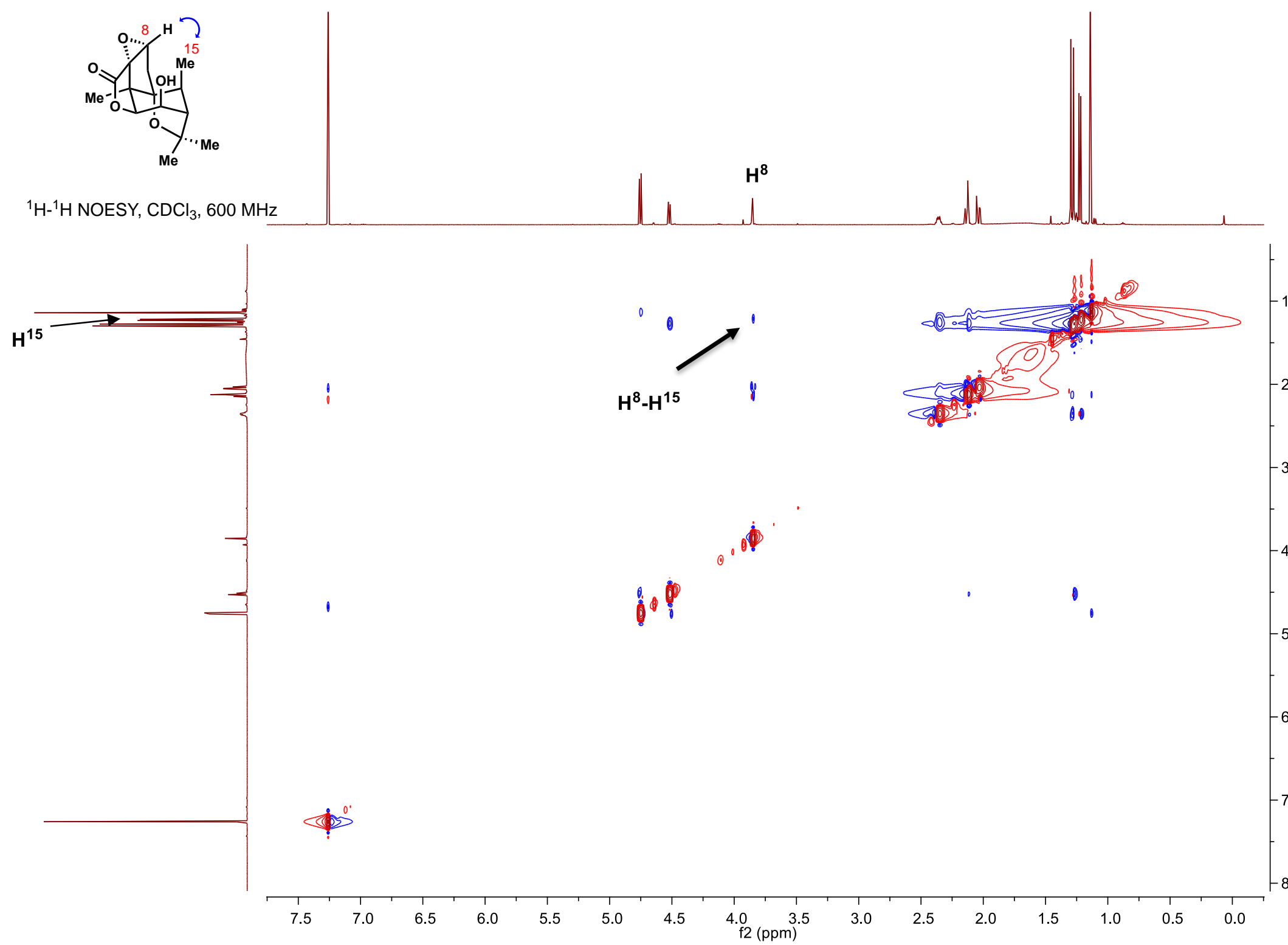



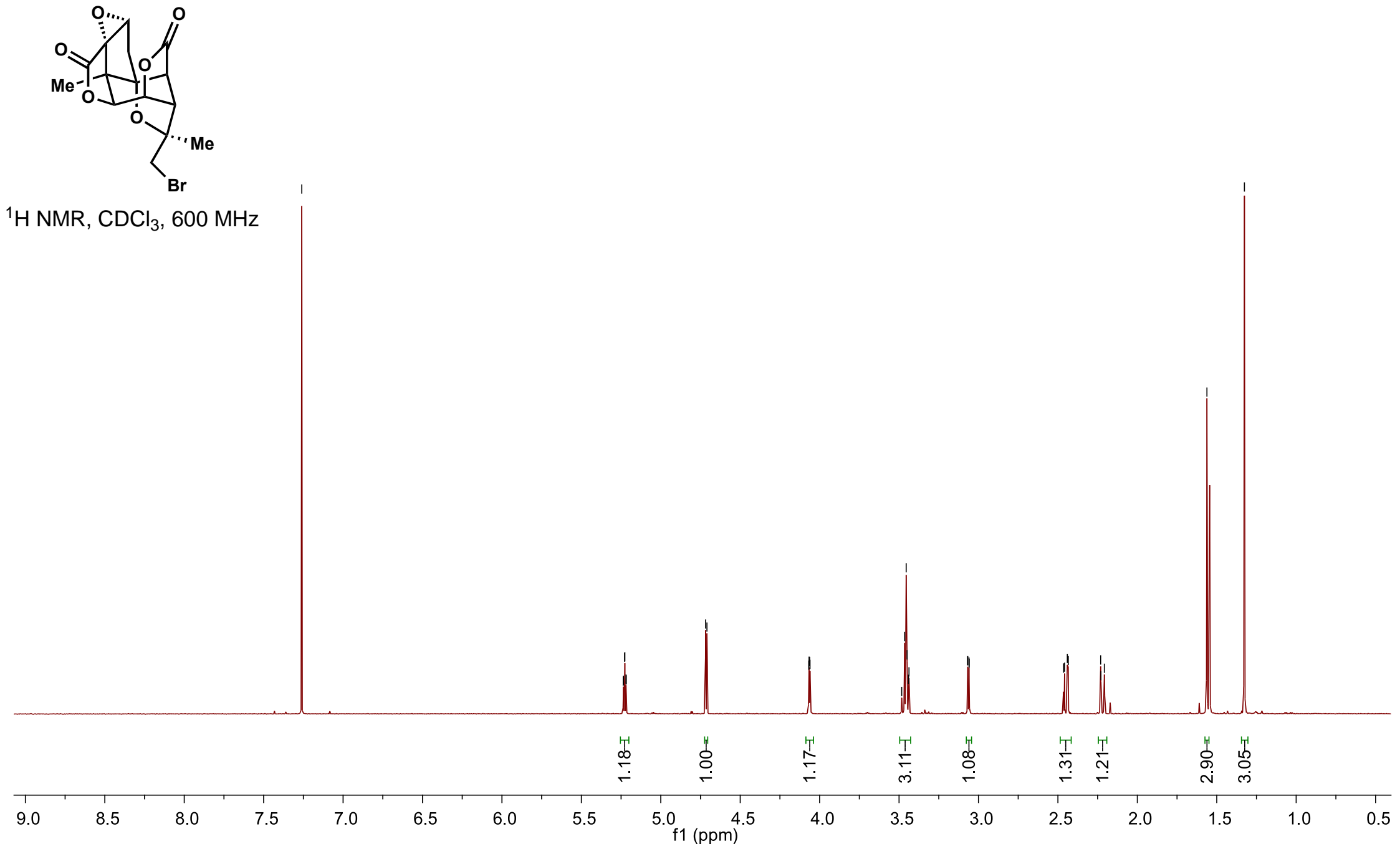
${ }^{13} \mathrm{C} \mathrm{NMR}, \mathrm{CDCl}_{3}, 150 \mathrm{MHz}$

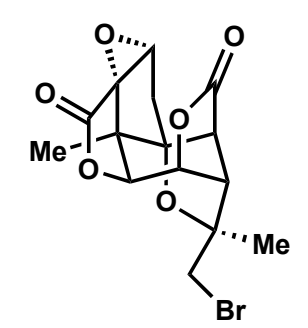



(3)
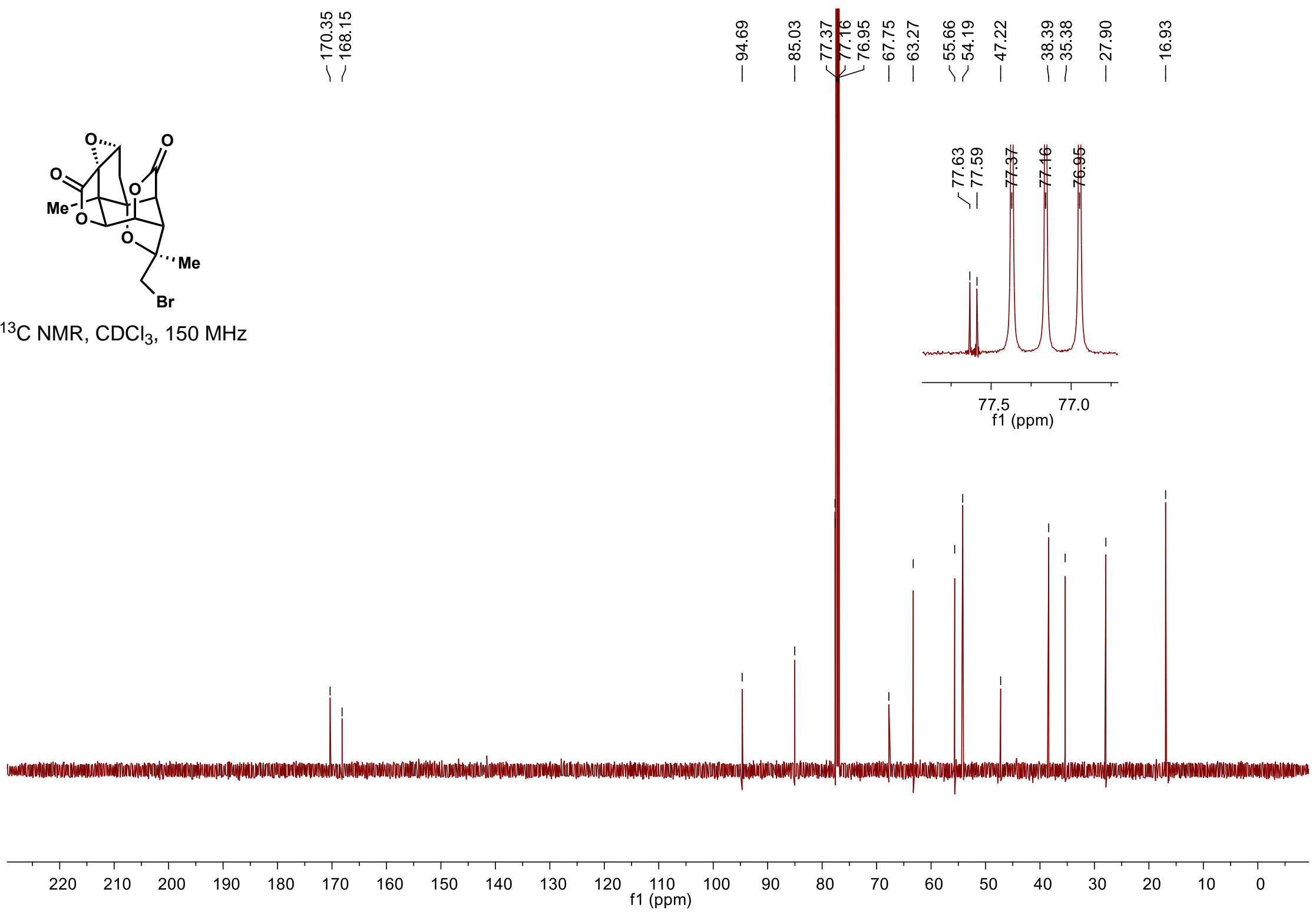

S76 


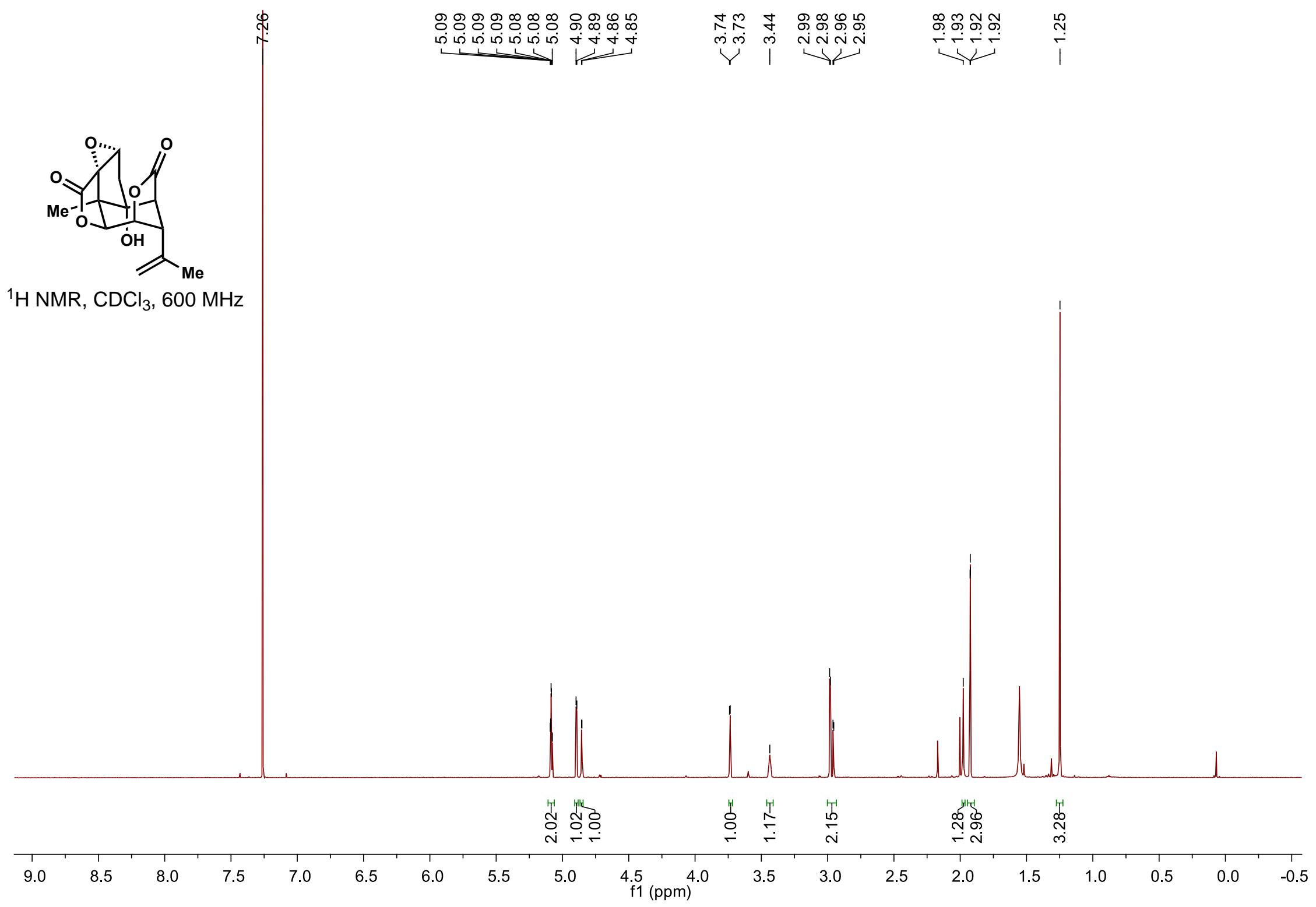




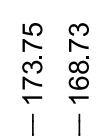

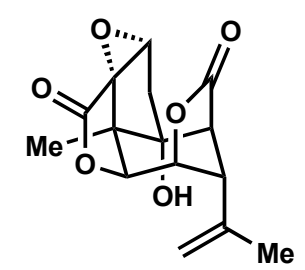

${ }^{13} \mathrm{C} \mathrm{NMR}, \mathrm{CDCl}_{3}, 150 \mathrm{MHz}$

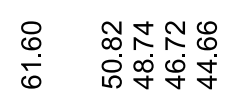

1 रा1

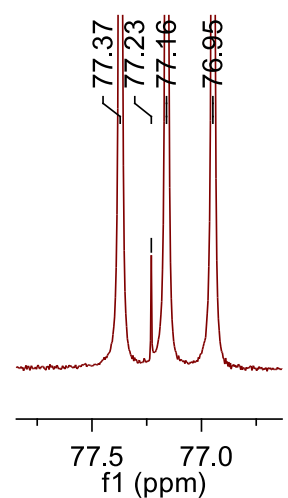

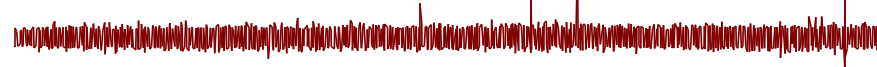

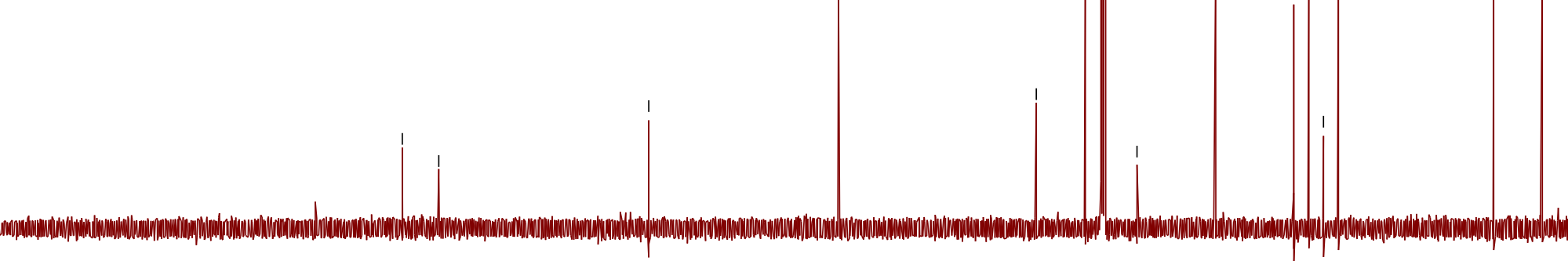



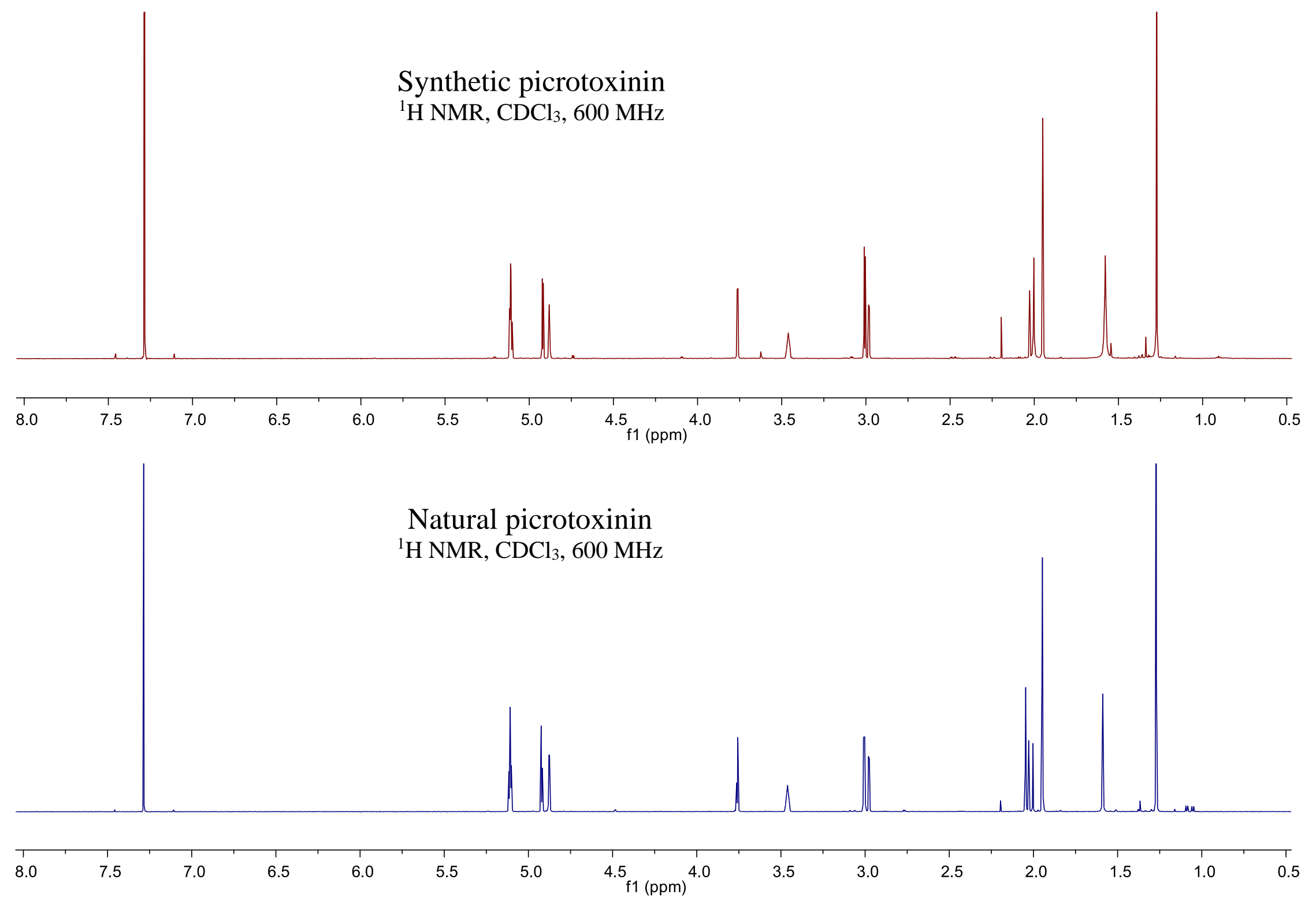
Synthetic picrotoxinin

${ }^{13} \mathrm{C}$ NMR, $\mathrm{CDCl}_{3}, 150 \mathrm{MHz}$

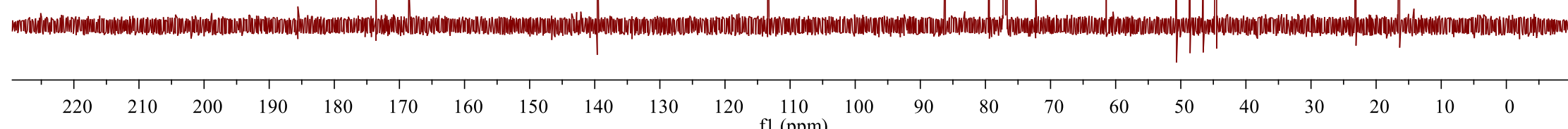

Natural picrotoxinin

${ }^{13} \mathrm{C} \mathrm{NMR}_{\mathrm{CDCl}}, 150 \mathrm{MHz}$

$\begin{array}{rllllllllllllllllllllllll}200 & 190 & 180 & 170 & 160 & 150 & 140 & 130 & 120 & \begin{array}{l}110 \\ \mathrm{fl}(\mathrm{ppm})\end{array} & 100 & 90 & 80 & 70 & 60 & 50 & 40 & 30 & 20 & 10 & 0 & \end{array}$ 


ك.

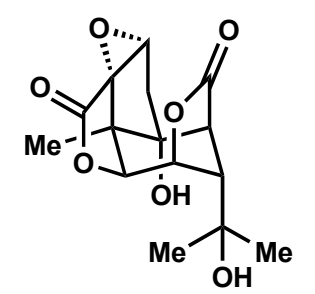

${ }^{1} \mathrm{H}$ NMR, $d$-acetone, $600 \mathrm{MHz}$

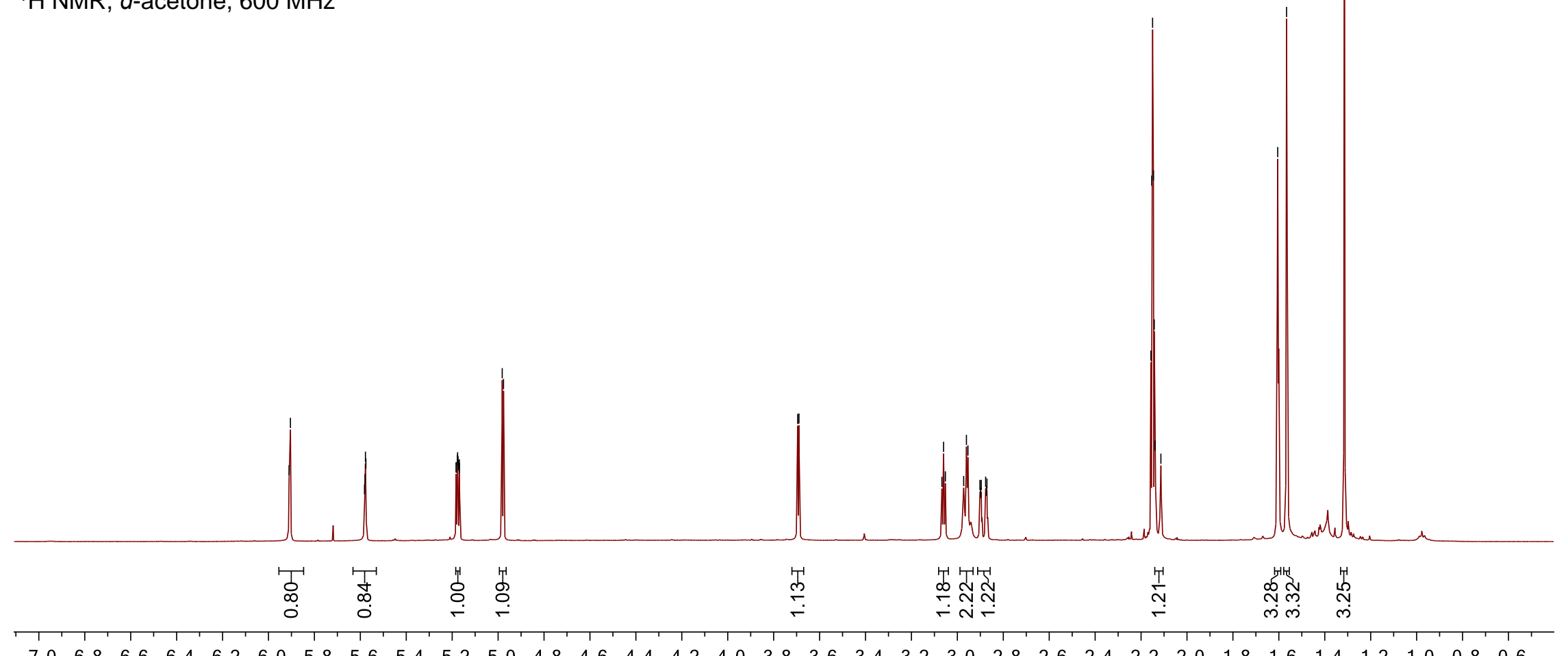

$\begin{array}{llllllllllllllllllllllllllllllllll}7.0 & 6.8 & 6.6 & 6.4 & 6.2 & 6.0 & 5.8 & 5.6 & 5.4 & 5.2 & 5.0 & 4.8 & 4.6 & 4.4 & 4.2 & 4.0 & 3.8 & 3.6 & 3.4 & 3.2 & 3.0 & 2.8 & 2.6 & 2.4 & 2.2 & 2.0 & 1.8 & 1.6 & 1.4 & 1.2 & 1.0 & 0.8 & 0.6\end{array}$ 


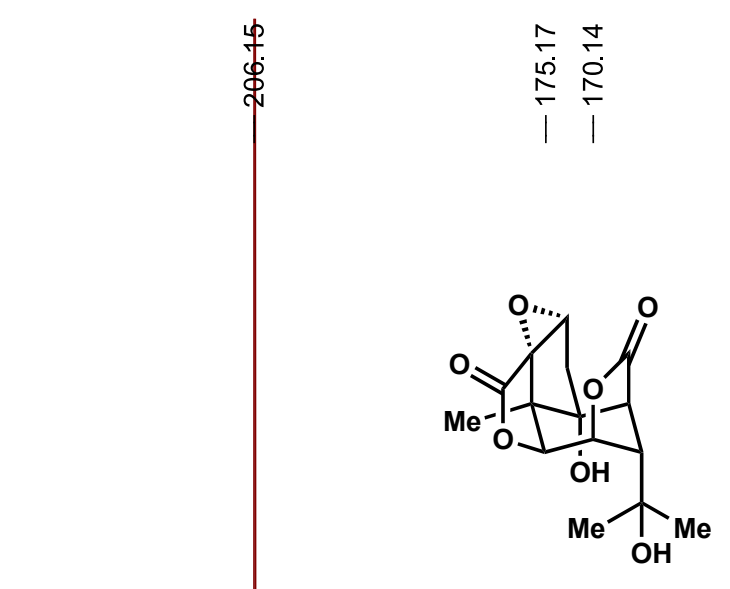

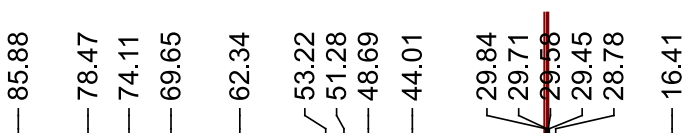

${ }^{13} \mathrm{C}$ NMR, $d$-acetone, $150 \mathrm{MHz}$

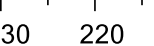

$\begin{array}{lll}210 & 200 \quad 190\end{array}$

180

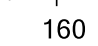




\section{X-ray data}

Intramolecular aldol product (2) (CCDC1999782)

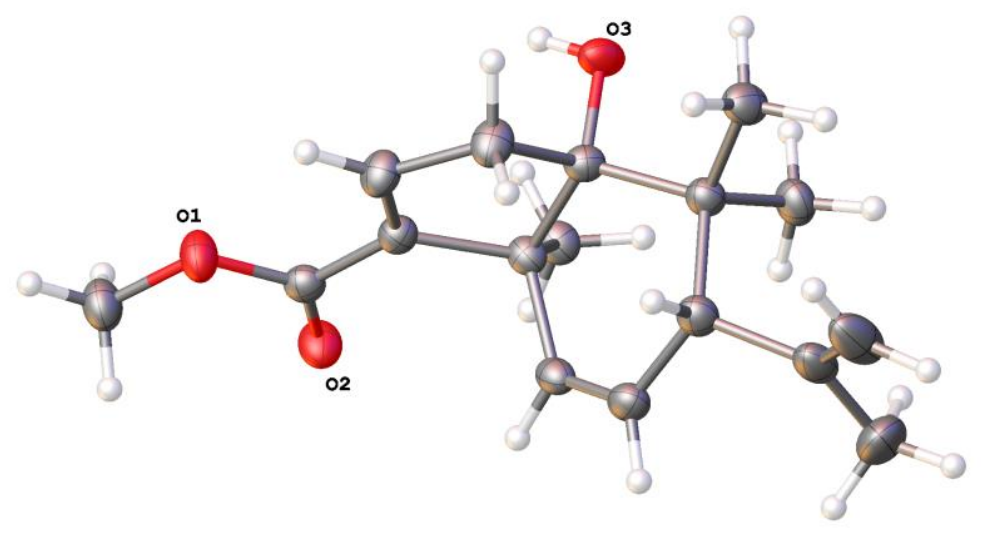

Table S1. Crystal data and structure refinement for shenvi124.

Identification code

Empirical formula

Formula weight

Temperature

Wavelength

Crystal system

Space group

Unit cell dimensions

Volume

$\mathrm{Z}$

Density (calculated)

Absorption coefficient

$\mathrm{F}(000)$

Crystal size

Theta range for data collection

Index ranges

Reflections collected

Independent reflections

Completeness to theta $=67.679^{\circ}$

Absorption correction

Max. and min. transmission

Refinement method

Data / restraints / parameters

Goodness-of-fit on $\mathrm{F}^{2}$

Final $\mathrm{R}$ indices [I>2sigma(I)]

$\mathrm{R}$ indices (all data)
SC2329

C17 H24 O3

276.36

$100.15 \mathrm{~K}$

$1.54178 \AA$

Orthorhombic

$\mathrm{P} 22_{12} 2_{1}$

$\mathrm{a}=7.1439(4) \AA$

$\alpha=90^{\circ}$.

$\mathrm{b}=7.9679(5) \AA$

$\beta=90^{\circ}$.

$\mathrm{c}=27.4909(11) \AA$

$\gamma=90^{\circ}$.

1564.83(15) $\AA^{3}$

4

$1.173 \mathrm{Mg} / \mathrm{m}^{3}$

$0.628 \mathrm{~mm}^{-1}$

600

$0.3 \times 0.24 \times 0.18 \mathrm{~mm}^{3}$

3.215 to $68.388^{\circ}$.

$-8<=\mathrm{h}<=8,-9<=\mathrm{k}<=9,-32<=1<=33$

9317

$2856[\mathrm{R}(\mathrm{int})=0.0338]$

$99.6 \%$

Semi-empirical from equivalents

0.5210 and 0.4340

Full-matrix least-squares on $\mathrm{F}^{2}$

2856 / 0 / 190

1.057

$\mathrm{R} 1=0.0340, \mathrm{wR} 2=0.0857$

$\mathrm{R} 1=0.0360, \mathrm{wR} 2=0.0868$ 
Absolute structure parameter

Extinction coefficient

Largest diff. peak and hole
$0.00(9)$

$\mathrm{n} / \mathrm{a}$

0.246 and -0.139 e. $\AA^{-3}$

Bromoetherification product (6) (CCDC1999783)

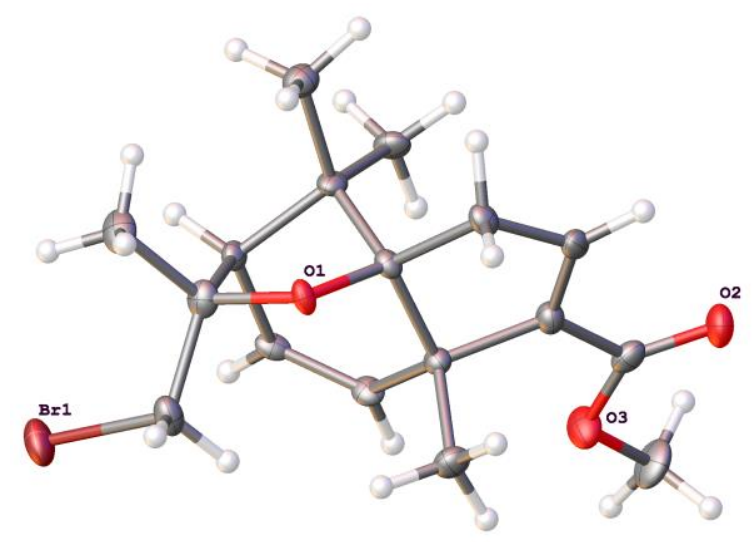

Table S2. Crystal data and structure refinement for shenvi118_0m_a.

Identification code

SC2385

Empirical formula

$\mathrm{C} 17 \mathrm{H} 23 \mathrm{Br} \mathrm{O} 3$

Formula weight

355.26

Temperature

$100.0 \mathrm{~K}$

Wavelength

$1.54178 \AA$

Crystal system

Hexagonal

Space group

P61

Unit cell dimensions

$\mathrm{a}=8.8468(15) \AA$

$\alpha=90^{\circ}$.

$\mathrm{b}=8.8468(15) \AA$

$\beta=90^{\circ}$.

$\mathrm{c}=35.599(6) \AA$

$\gamma=120^{\circ}$.

Volume

2412.9(9) $\AA^{3}$

$\mathrm{Z}$

6

Density (calculated)

$1.467 \mathrm{Mg} / \mathrm{m}^{3}$

Absorption coefficient

$\mathrm{F}(000)$

$3.545 \mathrm{~mm}^{-1}$

Crystal size

1104

Theta range for data collection

$0.25 \times 0.2 \times 0.1 \mathrm{~mm}^{3}$

Index ranges

Reflections collected

5.775 to $68.204^{\circ}$.

$-10<=\mathrm{h}<=10,-10<=\mathrm{k}<=10,-42<=\mathrm{l}<=42$

16091

Independent reflections

2947 [R(int) $=0.0625]$

Completeness to theta $=67.679^{\circ}$

$99.9 \%$

Absorption correction

Semi-empirical from equivalents

Max. and min. transmission

0.5849 and 0.4274

Refinement method

Full-matrix least-squares on $\mathrm{F}^{2}$

Data / restraints / parameters

2947 / 1 / 195 
Goodness-of-fit on $\mathrm{F}^{2}$

Final $\mathrm{R}$ indices [I>2sigma(I)]

$\mathrm{R}$ indices (all data)

Absolute structure parameter

Extinction coefficient

Largest diff. peak and hole
1.069

$\mathrm{R} 1=0.0358, \mathrm{wR} 2=0.0825$

$\mathrm{R} 1=0.0381, \mathrm{wR} 2=0.0835$

$0.052(13)$

$\mathrm{n} / \mathrm{a}$

0.318 and -0.539 e. $\AA^{-3}$

\section{Epoxidation product (7) (CCDC1999788)}

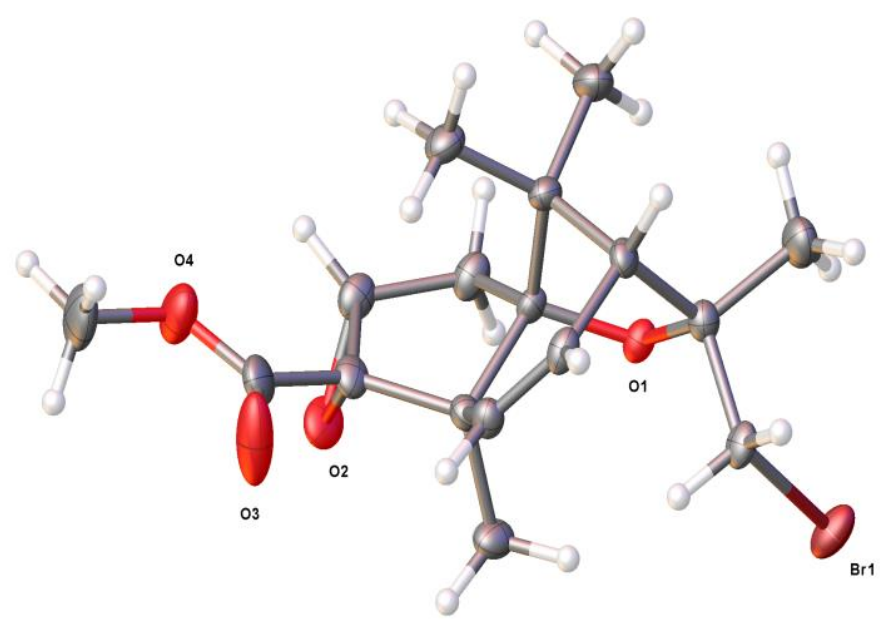

Table S3. Crystal data and structure refinement for Shenvi126.

Identification code

Empirical formula

$\mathrm{SC} 2425$

Molecular formula

$\mathrm{C} 17 \mathrm{H} 23 \mathrm{Br} \mathrm{O} 4$

Formula weight

$\mathrm{C} 17 \mathrm{H} 23 \mathrm{Br} \mathrm{O} 4$

Temperature

371.26

Wavelength

$100.0 \mathrm{~K}$

Crystal system

$0.71073 \AA$

Space group

Orthorhombic

Unit cell dimensions

$\mathrm{P} 22_{1} 2_{1}$

$a=9.9382(19) \AA$

$\alpha=90^{\circ}$.

$\mathrm{b}=11.216(2) \AA$

$\beta=90^{\circ}$.

$\mathrm{c}=14.840(3) \AA$

$\gamma=90^{\circ}$.

Volume

1654.2(5) $\AA^{3}$

Z

4

Density (calculated)

$1.491 \mathrm{Mg} / \mathrm{m}^{3}$

Absorption coefficient

$\mathrm{F}(000)$

$2.500 \mathrm{~mm}^{-1}$

Crystal size

768

$0.277 \times 0.234 \times 0.216 \mathrm{~mm}^{3}$ 
Crystal color, habit

Theta range for data collection

Index ranges

Reflections collected

Independent reflections

Completeness to theta $=25.000^{\circ}$

Absorption correction

Max. and min. transmission

Refinement method

Data / restraints / parameters

Goodness-of-fit on $\mathrm{F}^{2}$

Final $\mathrm{R}$ indices [I $>2 \operatorname{sigma}(\mathrm{I})]$

$\mathrm{R}$ indices (all data)

Absolute structure parameter

Extinction coefficient

Largest diff. peak and hole
Colorless Block

2.276 to $26.423^{\circ}$.

$-12<=\mathrm{h}<=12,-14<=\mathrm{k}<=14,-17<=\mathrm{l}<=18$

24212

$3393[\mathrm{R}($ int $)=0.0690, \mathrm{R}($ sigma $)=0.0538]$

$99.9 \%$

Semi-empirical from equivalents

0.0932 and 0.0571

Full-matrix least-squares on $\mathrm{F}^{2}$

3393 / 0 / 214

1.032

$\mathrm{R} 1=0.0315, \mathrm{wR} 2=0.0620$

$\mathrm{R} 1=0.0416, \mathrm{wR} 2=0.0643$

$0.032(6)$

$\mathrm{n} / \mathrm{a}$

0.304 and -0.343 e. $\AA^{-3}$

Dihydroxylation product (8) (CCDC1999787)

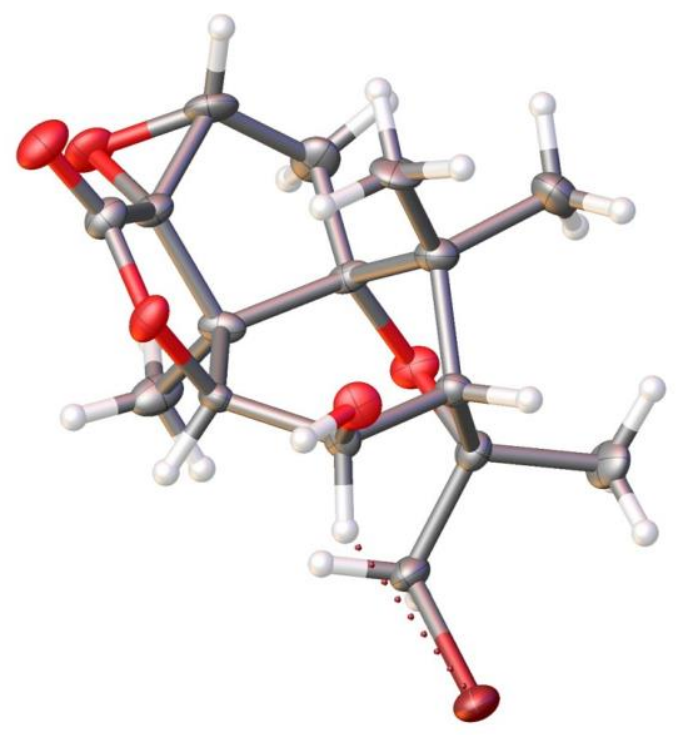

Table S4. Crystal data and structure refinement for shenvi178_0m_a_sq.

Identification code

Empirical formula

Formula weight

Temperature

Wavelength

Crystal system

Space group

Unit cell dimensions shenvi178

C16 H20.90 Br O5

373.14

$100.0 \mathrm{~K}$

$1.54178 \AA$

Orthorhombic

$\mathrm{P} 22_{1} 2_{1}$

$a=11.11210(10) \AA \quad \alpha=90^{\circ}$.

$\mathrm{b}=11.34500(10) \AA \quad \beta=90^{\circ}$. 
Volume

Z, Z'

Density (calculated)

Absorption coefficient

$\mathrm{F}(000)$

Crystal size

Theta range for data collection

Index ranges

Reflections collected

Independent reflections

Completeness to theta $=67.679^{\circ}$

Absorption correction

Max. and min. transmission

Refinement method

Data / restraints / parameters

Goodness-of-fit on $\mathrm{F}^{2}$

Final $\mathrm{R}$ indices [I>2sigma(I)]

$\mathrm{R}$ indices (all data)

Absolute structure parameter

Extinction coefficient

Largest diff. peak and hole $\mathrm{c}=24.5785(3) \AA \quad \gamma=90^{\circ}$.

3098.53(5) $\AA^{3}$

8,2

$1.600 \mathrm{Mg} / \mathrm{m}^{3}$

$3.814 \mathrm{~mm}^{-1}$

1535

$0.25 \times 0.23 \times 0.21 \mathrm{~mm}^{3}$

3.596 to $68.523^{\circ}$.

$-13<=\mathrm{h}<=13,-13<=\mathrm{k}<=13,-25<=1<=29$

32068

$5664[\mathrm{R}(\mathrm{int})=0.0582]$

$99.5 \%$

Multi-scan

0.7503 and 0.6547

Full-matrix least-squares on $\mathrm{F}^{2}$

5664 / 0 / 418

1.079

$\mathrm{R} 1=0.0575, \mathrm{wR} 2=0.1518$

$\mathrm{R} 1=0.0580, \mathrm{wR} 2=0.1523$

0.074(8)

$\mathrm{n} / \mathrm{a}$

3.120 and -0.514 e. $\AA^{-3}$ 
$\underline{\text { Ketone } 15 \text { (CCDC1999786) }}$

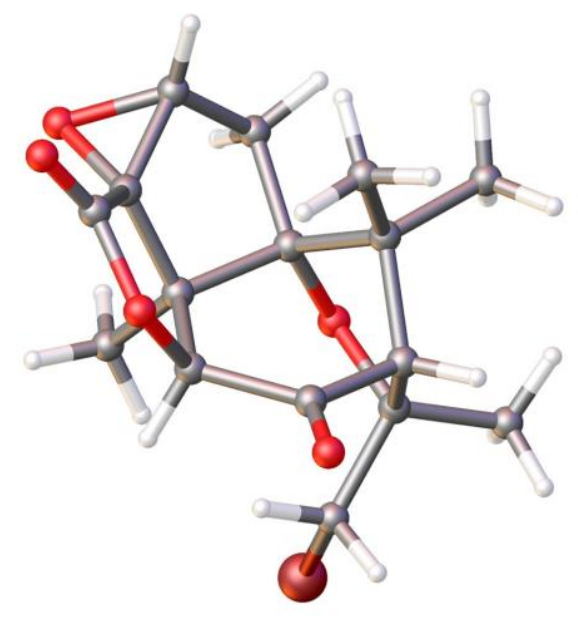

Table S5. Crystal data and structure refinement for shenvi197.

Identification code

shenvi197

Empirical formula

C16 H19 Br O5

Molecular formula

C16 H19 Br O5

Formula weight

371.22

Temperature

$100.0 \mathrm{~K}$

Wavelength

$0.71073 \AA$

Crystal system

Monoclinic

Space group

P 1211

Unit cell dimensions

$\mathrm{a}=8.7464(5) \AA$

$\alpha=90^{\circ}$.

$\mathrm{b}=8.1031(6) \AA$

$\beta=100.894(2)^{\circ}$.

$\mathrm{c}=10.9434(8) \AA$

$\gamma=90^{\circ}$.

Volume

761.61(9) $\AA^{3}$

Z

2

Density (calculated)

$1.619 \mathrm{Mg} / \mathrm{m}^{3}$

Absorption coefficient

$\mathrm{F}(000)$

$2.720 \mathrm{~mm}^{-1}$

380

Crystal size

Crystal color, habit

Theta range for data collection

$0.3 \times 0.25 \times 0.2 \mathrm{~mm}^{3}$

colourless block

2.742 to $28.304^{\circ}$.

Index ranges

Reflections collected

$-7<=\mathrm{h}<=11,-10<=\mathrm{k}<=10,-14<=\mathrm{l}<=14$

6171

3548 [R(int) $=0.0217]$

$98.3 \%$

Completeness to theta $=25.242^{\circ}$

Semi-empirical from equivalents

Absorption correction

Max. and min. transmission

0.4920 and 0.4421

Refinement method

Full-matrix least-squares on $\mathrm{F}^{2}$

Data / restraints / parameters

3548 / 1 / 203

Goodness-of-fit on $\mathrm{F}^{2}$

1.051

Final $\mathrm{R}$ indices [I>2sigma(I)]

$\mathrm{R} 1=0.0280, \mathrm{wR} 2=0.0608$

$\mathrm{R}$ indices (all data)

$\mathrm{R} 1=0.0313, \mathrm{wR} 2=0.0622$ 
Absolute structure parameter

Extinction coefficient

Largest diff. peak and hole
$-0.017(5)$

n/a

0.778 and -0.547 e. $\AA^{-3}$ 


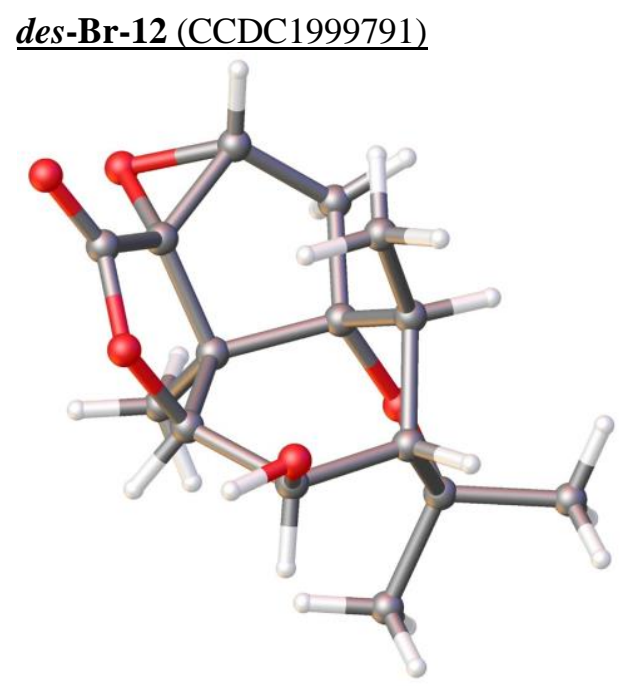

Table S6. Crystal data and structure refinement for Shenvi220.

Identification code

shenvi220

Empirical formula

C15 H20 O5

Molecular formula

$\mathrm{C} 15 \mathrm{H} 20 \mathrm{O} 5$

Formula weight

280.31

Temperature

$100.0 \mathrm{~K}$

Wavelength

$1.54178 \AA$

Crystal system

Monoclinic

Space group

P 1211

Unit cell dimensions

$a=7.33000(10) \AA$

$\alpha=90^{\circ}$.

$\mathrm{b}=10.37940(10) \AA$

$\beta=101.4390(10)^{\circ}$.

$\mathrm{c}=8.96710(10) \AA$

$\gamma=90^{\circ}$.

Volume

668.674(14) $\AA^{3}$

Z

2

Density (calculated)

$1.392 \mathrm{Mg} / \mathrm{m}^{3}$

Absorption coefficient

$\mathrm{F}(000)$

$0.862 \mathrm{~mm}^{-1}$

Crystal size

Crystal color, habit

Theta range for data collection

300

Index ranges

Reflections collected

0.17 x 0.15 x $0.085 \mathrm{~mm}^{3}$

colorless block

5.032 to $70.114^{\circ}$.

$-8<=\mathrm{h}<=8,-12<=\mathrm{k}<=12,-10<=\mathrm{l}<=10$

11000

Independent reflections

$2506[\mathrm{R}(\mathrm{int})=0.0245]$

Completeness to theta $=67.500^{\circ}$

$100.0 \%$

Absorption correction

Semi-empirical from equivalents

Max. and min. transmission

0.7533 and 0.6867

Refinement method

Full-matrix least-squares on $\mathrm{F}^{2}$

Data / restraints / parameters

$2506 / 1 / 191$

Goodness-of-fit on $\mathrm{F}^{2}$

1.053

Final $\mathrm{R}$ indices [I $>2 \operatorname{sigma}(\mathrm{I})]$

$\mathrm{R} 1=0.0248, \mathrm{wR} 2=0.0637$

$\mathrm{R}$ indices (all data)

$\mathrm{R} 1=0.0250, \mathrm{wR} 2=0.0638$ 
Absolute structure parameter

Extinction coefficient

Largest diff. peak and hole
$-0.04(4)$

$0.0044(9)$

0.220 and -0.146 e. $\AA^{-3}$ 


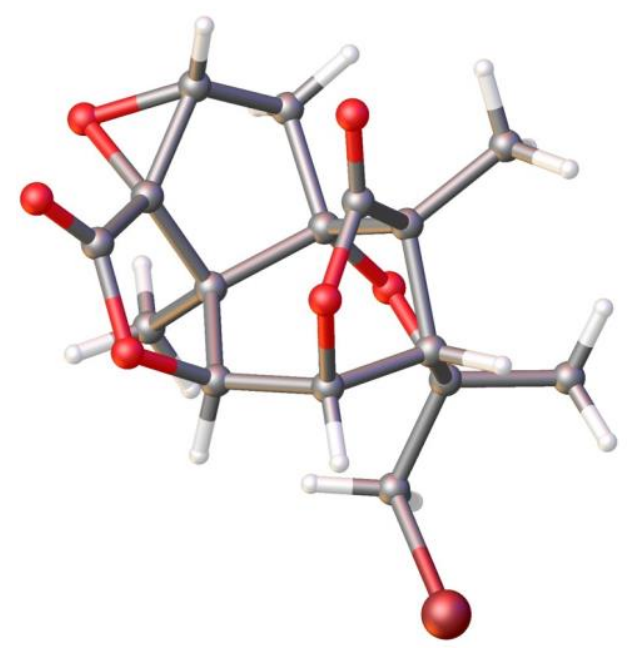

Table S7. Crystal data and structure refinement for Shenvi211_a.

Identification code

Empirical formula

shenvi211

Formula weight

C16 $\mathrm{H} 17$ Br O6

Temperature

385.20

Wavelength

$100.0 \mathrm{~K}$

Crystal system

$0.71073 \AA$

Space group

Orthorhombic

Unit cell dimensions

$\mathrm{P} 2{ }_{1} 2_{1} 2_{1}$

$\mathrm{a}=8.0004(4) \AA$

$\alpha=90^{\circ}$.

$\mathrm{b}=11.8702(5) \AA$

$\beta=90^{\circ}$.

$\mathrm{c}=15.6494(7) \AA$

$\gamma=90^{\circ}$.

Volume

1486.17(12) $\AA^{3}$

Z

4

Density (calculated)

$1.722 \mathrm{Mg} / \mathrm{m}^{3}$

Absorption coefficient

$\mathrm{F}(000)$

$2.796 \mathrm{~mm}^{-1}$

Crystal size

784

Theta range for data collection

$0.25 \times 0.2 \times 0.175 \mathrm{~mm}^{3}$

Index ranges

Reflections collected

2.153 to $26.371^{\circ}$.

$-10<=\mathrm{h}<=9,-14<=\mathrm{k}<=14,-17<=\mathrm{l}<=19$

Independent reflections

Completeness to theta $=25.242^{\circ}$

12668

3027 [R(int $)=0.0319]$

$99.9 \%$

Absorption correction

Semi-empirical from equivalents

Max. and min. transmission

0.4910 and 0.4261

Refinement method

Full-matrix least-squares on $\mathrm{F}^{2}$

Data / restraints / parameters

3027 / 0 / 211

Goodness-of-fit on $\mathrm{F}^{2}$

1.064

Final $\mathrm{R}$ indices [I $>2 \operatorname{sigma}(\mathrm{I})]$

$\mathrm{R} 1=0.0255, \mathrm{wR} 2=0.0615$

$\mathrm{R}$ indices (all data)

$\mathrm{R} 1=0.0280, \mathrm{wR} 2=0.0623$

Absolute structure parameter

$-0.003(4)$ 
Extinction coefficient

Largest diff. peak and hole $\mathrm{n} / \mathrm{a}$

0.461 and -0.246 e. $\AA^{-3}$

5-methyl-picrotoxinin (20) (CCDC1999784)

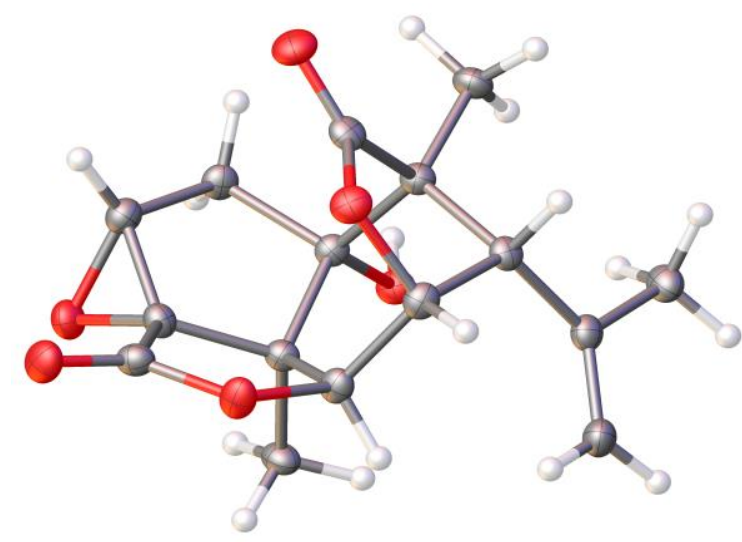

Table S8. Crystal data and structure refinement for Shenvi137.

Identification code

Empirical formula

shenvi137

Molecular formula

C16 H18 O6

Formula weight

C16 H18 O6

Temperature

306.30

Wavelength

$100.0 \mathrm{~K}$

Crystal system

$1.54178 \AA$

Space group

Orthorhombic

Unit cell dimensions

$\mathrm{P} 2{ }_{1} 2_{1} 2_{1}$

$\mathrm{a}=8.1071(7) \AA$

$\alpha=90^{\circ}$.

$\mathrm{b}=11.4912(10) \AA$

$\beta=90^{\circ}$.

$\mathrm{c}=14.8574(12) \AA$

Volume

1384.1(2) $\AA^{3}$

Z

4

Density (calculated)

$1.470 \mathrm{Mg} / \mathrm{m}^{3}$

Absorption coefficient

$\mathrm{F}(000)$

$0.946 \mathrm{~mm}^{-1}$

Crystal size

Crystal color, habit

Theta range for data collection

648

$0.4 \times 0.35 \times 0.2 \mathrm{~mm}^{3}$

colorless block

4.865 to $72.467^{\circ}$.

Index ranges

$-9<=\mathrm{h}<=9,-14<=\mathrm{k}<=14,-17<=1<=18$

Reflections collected

12109

Independent reflections

$2706[\mathrm{R}$ (int) $=0.0495]$

Completeness to theta $=67.500^{\circ}$

$100.0 \%$

Absorption correction

Semi-empirical from equivalents

Max. and min. transmission

0.7536 and 0.6163

Refinement method

Full-matrix least-squares on $\mathrm{F}^{2}$ 
Data / restraints / parameters

Goodness-of-fit on $\mathrm{F}^{2}$

Final $R$ indices [I $>2 \operatorname{sigma}(\mathrm{I})]$

$\mathrm{R}$ indices (all data)

Absolute structure parameter

Largest diff. peak and hole
$2706 / 0 / 204$

1.070

$\mathrm{R} 1=0.0290, \mathrm{wR} 2=0.0734$

$\mathrm{R} 1=0.0291, \mathrm{wR} 2=0.0735$

$-0.02(5)$

0.249 and -0.157 e. $\AA^{-3}$

Bromo-picrotoxinin (SI-3) (CCDC1999792)

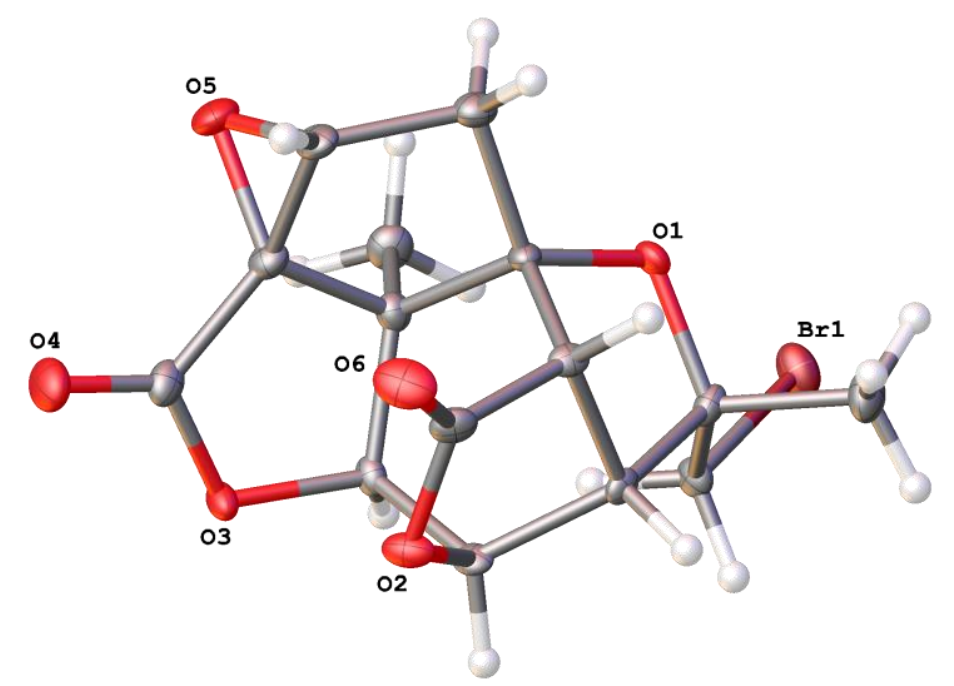

Table S9. Crystal data and structure refinement for shenvi140_0m_a.

Identification code

Empirical formula

Formula weight

Temperature

Wavelength

Crystal system

Space group

Unit cell dimensions

Volume

Z

Density (calculated)

Absorption coefficient

$\mathrm{F}(000)$

Crystal size

Theta range for data collection

Index ranges

Reflections collected

Independent reflections

Completeness to theta $=25.242^{\circ}$

Absorption correction

Max. and min. transmission
ASC2679

C15 H15 Br O6

371.18

$100.0 \mathrm{~K}$

$0.71073 \AA$

Tetragonal

$\mathrm{P}_{3}$

$\mathrm{a}=7.0612(8) \AA$

$\alpha=90^{\circ}$.

$\beta=90^{\circ}$.

$\mathrm{b}=7.0612(8) \AA$

$\mathrm{c}=28.368(3) \AA$

$\gamma=90^{\circ}$.
$1414.5(4) \AA^{3}$

4

$1.743 \mathrm{Mg} / \mathrm{m}^{3}$

$2.935 \mathrm{~mm}^{-1}$

752

$0.34 \times 0.34 \times 0.32 \mathrm{~mm}^{3}$

2.872 to $28.279^{\circ}$.

$-9<=\mathrm{h}<=9,-9<=\mathrm{k}<=8,-37<=1<=37$

12634

$3506[\mathrm{R}$ (int) $=0.0563]$

$99.9 \%$

Semi-empirical from equivalents

0.7457 and 0.6163 
Refinement method

Data / restraints / parameters

Goodness-of-fit on $\mathrm{F}^{2}$

Final R indices [I $>2 \operatorname{sigma}(\mathrm{I})]$

$\mathrm{R}$ indices (all data)

Absolute structure parameter

Extinction coefficient

Largest diff. peak and hole
Full-matrix least-squares on $\mathrm{F}^{2}$

3506 / 1 / 201

0.991

$\mathrm{R} 1=0.0364, \mathrm{wR} 2=0.0833$

$\mathrm{R} 1=0.0421, \mathrm{wR} 2=0.0845$

$0.015(13)$ [stereochemistry confirmed]

$\mathrm{n} / \mathrm{a}$

0.869 and -0.384 e. $\AA^{-3}$

$\underline{\text { Picrotoxinin (1) }}$ (CCDC1999790)

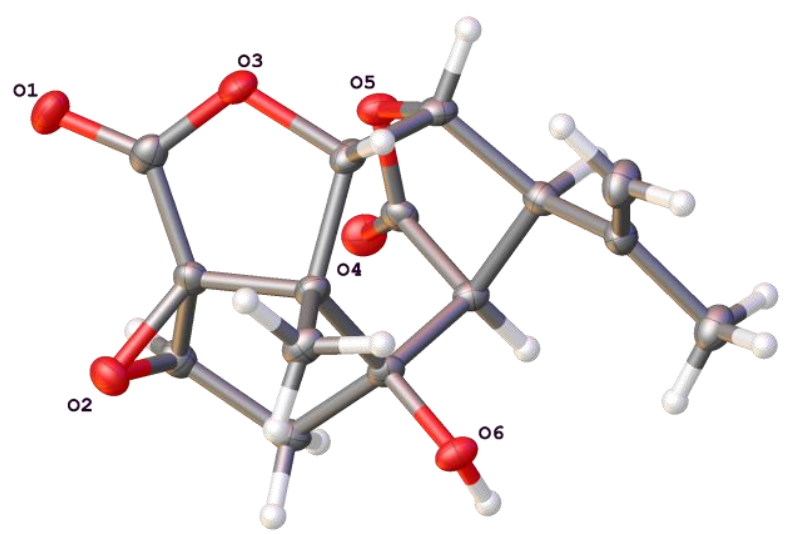

Table S10. Crystal data and structure refinement for shenvi145.

Identification code

Empirical formula

Formula weight

Temperature

Wavelength

Crystal system

Space group

Unit cell dimensions

Volume

Z, Z'

Density (calculated)

Absorption coefficient

$\mathrm{F}(000)$

Crystal size

Theta range for data collection

Index ranges

Reflections collected

Independent reflections

Completeness to theta $=67.679^{\circ}$

Absorption correction
2711

C15 H16 O6

292.28

$100.0 \mathrm{~K}$

$1.54178 \AA$

Monoclinic

P 21

$\mathrm{a}=15.2385(5) \AA$

$\alpha=90^{\circ}$.

$\mathrm{b}=11.3399(4) \AA$

$\beta=115.9850(10)^{\circ}$.

$\mathrm{c}=17.2881(5) \AA$ $\gamma=90^{\circ}$.

2685.43(15) $\AA^{3}$

8,4

$1.446 \mathrm{Mg} / \mathrm{m}^{3}$

$0.948 \mathrm{~mm}^{-1}$

1232

$0.33 \times 0.28 \times 0.26 \mathrm{~mm}^{3}$

2.843 to $72.608^{\circ}$.

$-18<=\mathrm{h}<=18,-13<=\mathrm{k}<=12,-21<=1<=18$

30798

$10212[\mathrm{R}(\mathrm{int})=0.0451]$

$99.8 \%$

Semi-empirical from equivalents 
Max. and min. transmission

Refinement method

Data / restraints / parameters

Goodness-of-fit on $\mathrm{F}^{2}$

Final $\mathrm{R}$ indices [I $>2 \operatorname{sigma}(\mathrm{I})]$

$\mathrm{R}$ indices (all data)

Absolute structure parameter

Extinction coefficient

Largest diff. peak and hole
0.7536 and 0.6661

Full-matrix least-squares on $\mathrm{F}^{2}$

10212 / 1 / 769

1.023

$\mathrm{R} 1=0.0317, \mathrm{wR} 2=0.0782$

$\mathrm{R} 1=0.0329, \mathrm{wR} 2=0.0791$

$0.08(5)$

$\mathrm{n} / \mathrm{a}$

0.189 and -0.235 e. $\AA^{-3}$

\section{$\underline{\text { Picrotin (19) (CCDC1999785) }}$}

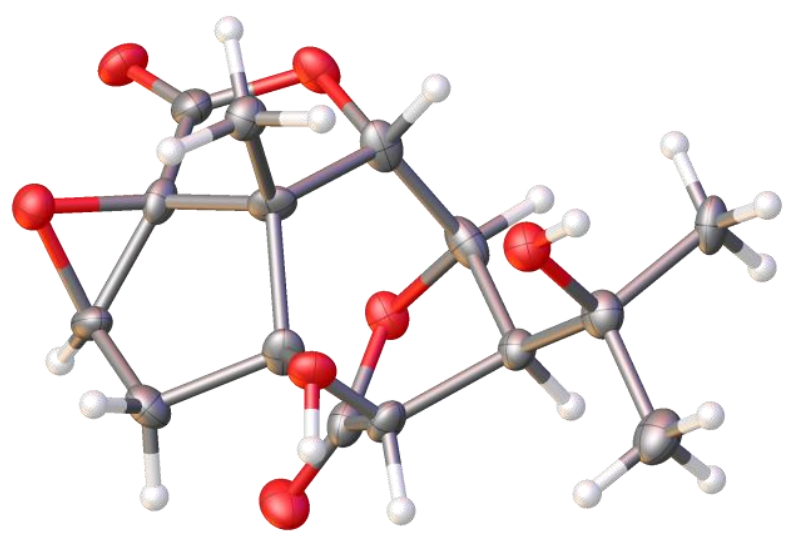

Table S11. Crystal data and structure refinement for shenvi146_0m_a.

Identification code

Empirical formula

Formula weight

Temperature

Wavelength

Crystal system

Space group

Unit cell dimensions

Volume

$\mathrm{Z}$

Density (calculated)

Absorption coefficient

$\mathrm{F}(000)$ shenvi146

C15 H18 O7

310.29

$100.0 \mathrm{~K}$

$1.54178 \AA$

Orthorhombic

$\mathrm{P} 22_{1} 2_{1}$

$\mathrm{a}=7.0934(2) \AA \quad \alpha=90^{\circ}$.

$\mathrm{b}=11.9278(4) \AA \quad \beta=90^{\circ}$.

$\mathrm{c}=32.7898(11) \AA \quad \gamma=90^{\circ}$.

2774.30(15) $\AA^{3}$

8

$1.486 \mathrm{Mg} / \mathrm{m}^{3}$

$1.006 \mathrm{~mm}^{-1}$

1312 
Crystal size

Theta range for data collection

Index ranges

Reflections collected

Independent reflections

Completeness to theta $=67.679^{\circ}$

Absorption correction

Max. and min. transmission

Refinement method

Data / restraints / parameters

Goodness-of-fit on $\mathrm{F}^{2}$

Final $\mathrm{R}$ indices [I>2sigma(I)]

$\mathrm{R}$ indices (all data)

Absolute structure parameter

Extinction coefficient

Largest diff. peak and hole
$0.26 \times 0.07 \times 0.05 \mathrm{~mm}^{3}$

3.944 to $68.275^{\circ}$.

$-8<=\mathrm{h}<=8,-14<=\mathrm{k}<=14,-38<=1<=39$

16014

$4873[\mathrm{R}(\mathrm{int})=0.0620]$

$98.6 \%$

Semi-empirical from equivalents

0.7531 and 0.6369

Full-matrix least-squares on $\mathrm{F}^{2}$

4873 / 0 / 416

1.134

$\mathrm{R} 1=0.0566, \mathrm{wR} 2=0.1356$

$\mathrm{R} 1=0.0670, \mathrm{wR} 2=0.1424$

0.20(12)

$\mathrm{n} / \mathrm{a}$

0.320 and -0.319 e. $\AA^{-3}$ 